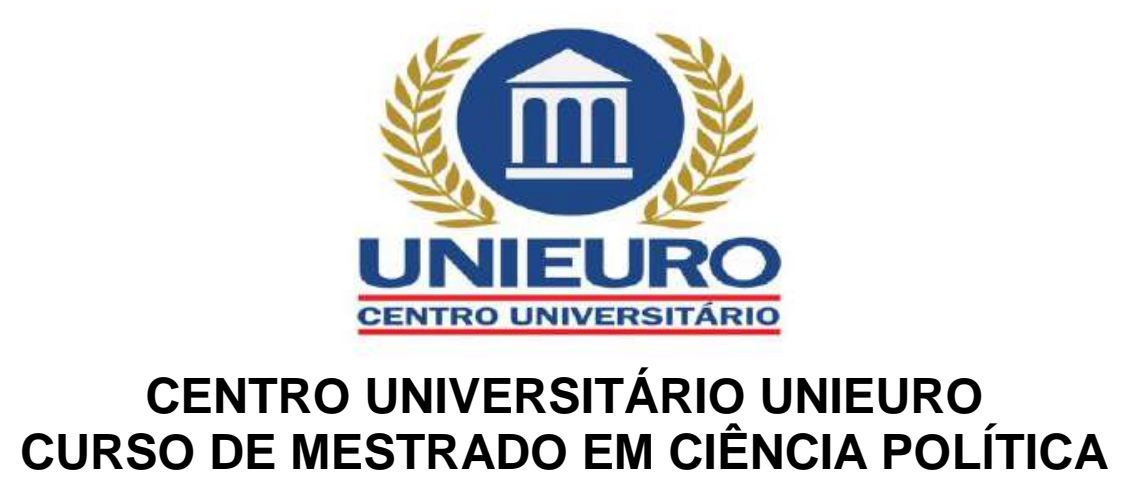

Lucas Freitas de Souza

O ABORTO DA LEI: UM ESTUDO COMPARATIVO DA QUESTÃO DO BIOPODER NO BRASIL E NO URUGUAI 
Lucas Freitas de Souza

\section{O ABORTO DA LEI: UM ESTUDO COMPARATIVO DA QUESTÃO DO BIOPODER NO BRASIL E NO URUGUAI}

Dissertação apresentado ao Centro Universitário - Unieuro, como requisito parcial do Curso de Mestrado em Ciência Política, para obtenção do título de Mestre.

Área de Concentração: Direitos Humanos, Cidadania e Violência.

Linha de Pesquisa: Estado, Políticas Públicas e Cidadania.

Orientador: Professor Dr. Manoel Santana Cardoso 
Ficha catalográfica elaborada pela Bibliotecária Marina Carvalho de Souza CRB13/823

S719a Souza, Lucas Freitas de.

O ABORTO DA LEI: Um Estudo comparativo da questão do Biopoder no Brasil e no Uruguai - Brasília: Centro Universitário UNIEURO, 2017.

128f: il ; color.

Dissertação (Mestrado) - Mestrado em Ciência Política. Centro Universitário UNIEURO.

1. Aborto 2. Biopoder 3. Debate Legislativo 4. Congresso Nacional 5. Direitos Sexuais e Reprodutivos I. CARDOSO, Manoel Santana. (Orientador) II. FREITAS, Lídia de Oliveira Xavier. (Coordenadora) III. Título.

CDU: 342.537.3(81)(899)

Proibida a reprodução total ou parcial, de qualquer forma ou por qualquer meio eletrônico ou mecânico, inclusive através de processos xerográficos, sem permissão expressa do Autor. (Artigo 184 do Código Penal Brasileiro, com a nova redação dada pela Lei n.8.635, de 16-03-1993). 
Lucas Freitas de Souza

\title{
O ABORTO DA LEI: UM ESTUDO COMPARATIVO DA QUESTÃO DO BIOPODER NO BRASIL E NO URUGUAI
}

\section{BANCA EXAMINADORA}

\author{
Prof. Dr. Manoel Santana Cardoso \\ (UNIEURO - Membro Interno - Orientador) \\ Prof. Dr. Renato Zerbini Ribeiro Leão \\ (UNIEURO - Membro Interno) \\ Prof $^{a}$. Dra. Verônica Teixeira Marques \\ (UNIT - Membro Externo)
}


A minha família e amigos. Ao meu orientador por todo auxílio. A Deus por me manter firme para a luta. Ao conhecimento humano, o verdadeiro elixir da vida eterna. 


\section{AGRADECIMENTOS}

Considerando esta dissertação como resultado de uma caminhada que começou nos primeiros semestres do curso, agradeço de antemão a todos que de alguma forma passaram pela minha vida e contribuíram para a minha formação intelectual e conclusão desta etapa.

Agradeço, em especial, para algumas pessoas pela contribuição direta na construção deste trabalho:

Aos meus pais, Pedro e Vanusa, que com muito esforço e dedicação sempre me incentivaram a continuar esta jornada, e mesmo sob tempestades, jamais desistir.

A minha irmã, Thais, que nos momentos difíceis sempre estava pronta para me socorrer.

A Nathália, saiba que concluo este curso hoje graças a você, auxílio sem o qual não poderia ter continuado.

A Vera, Junior e Elô, obrigado por terem me acolhido. Saibam que tal fato foi essencial para o desenvolvimento e conclusão deste projeto.

Ao Centro Universitário Euro Americano pelo apoio durante a pesquisa.

Aos membros do Congresso Nacional do Brasil pela participação na pesquisa e ao Congresso Nacional Uruguaio por disponibilizar eletronicamente as atas das votações.

Ao meu Orientador, Professor Dr. Manoel Santana Cardoso, obrigado por todas as horas de conversa, debates e sugestões. Saiba que sempre será para mim fonte de exemplo a ser seguido.

A Deus, por todas a bênçãos concedidas. 
"A História é escrita pelas grandes transgressões

De quem mudou o mundo com suas inquietações". 


\section{RESUMO}

A presente pesquisa visa a comparação da atuação do biopoder no Brasil e no Uruguai (1990 - 2017), no que tange, especificamente, no debate a respeito do aborto. Tema extremamente questionado no Congresso Brasileiro, o aborto é debatido desde o regime militar, porém, sem êxito em seu debate. Por sua vez, o Uruguai, em ato histórico, regulamentou o aborto em 2012. Para realização desta pesquisa foi utilizado um estudo bibliográfico, qualitativo, de natureza analítica, aplicada e indutiva, no que diz respeito ao biopoder e sua atuação nos parlamentos brasileiros e uruguaio, assim como a análise do procedimento legislativo em ambos os parlamentos. Foi realizada uma pesquisa de campo, por meio de questionário, dentro do Congresso Brasileiro, aplicado nas Comissões de Seguridade Social e Família e Constituição, Cidadania e Justiça (2017), com o objetivo de identificar fatores relativos ao tema biopoder. Os dados referentes ao Uruguai foram obtidos com o uso de pesquisa bibliográfica, realizada no banco de dados do parlamento uruguaio, tendo como base as atas do processo de votação e debate da lei do aborto em 2012. Primeiramente, é realizada uma contextualização quanto aos conceitos básicos necessários para 0 desenvolvimento da pesquisa, tais como: Estado, Poder, Biopoder, Dominação do corpo feminino e Direitos Sexuais e Reprodutivos. No segundo capítulo é realizada uma contextualização histórica e evolutiva do debate a respeito do aborto em ambos os parlamentos. O terceiro capítulo apresenta gráficos com os resultados das pesquisas realizadas. Conclui-se, comprovando a hipótese apresentada inicialmente, de que o Congresso Nacional Brasileiro pratica uma política de abstenção de temas e debates polêmicos. Apresentando os efeitos das bancadas, blocos e coligações. Por último é apresentado as múltiplas faces do aborto. O presente trabalho não pretende ser conclusivo em relação às questões tratadas, mas chamar a atenção, de forma provocativa, para que outros pesquisadores vejam nele um objeto de interesse, tendo em vista as ricas interações sociais que o envolvem. É tema de importância ao qual os pesquisadores, das diversas áreas do conhecimento, podem agregar os resultados de seus estudos

Palavras-chave: Aborto, Biopoder, Debate Legislativo, Congresso Nacional, Direitos Sexuais e Reprodutivos. 


\begin{abstract}
This research compares the biopower interection in Brazil and Uruguay (1990-2017), specifically in the debate on the abortion. Abortion is a subject extremely questioned in the Brazilian Congress since the military regime, however unsuccessfully. On the other hand, Uruguay, in a historical act, regulated abortion in 2012. A qualitative, analytical, applied and inductive bibliographical study was carried out for biopower and its performance on Brazilian and Uruguayan parliaments. As well as the analysis of legislative procedure in both parliaments. It was realized a field research through questionnaire in the Brazilian Congress, which was applied on the Social Security and Family and Constitution, Citizenship and Justice Commissions (2017). This questionnaire has the goal to identify factors related to the biopower theme. The Uruguayan data were obtained through the use of bibliographical research, realized in database of the Uruguayan parliament, which its foundation on the minutes of the voting and debate process of the abortion law in 2012. First of all, a contextualization is realized regarding the basic concepts necessary to the research development, such as: State, Power, Biopwer, Female body and sexual and reproductive rights. Is realized in the second chapter a historical and evolutionary contextualization of the debate about abortion in both parliaments. The third chapter presents graphs about the results of the search. Proving the hypothesis shown, we can conclude that the Brazilian National Congress practises a policy of abstention from controversial issues and debates. Showing the affects of benchs, blocks and coalitions. Finally the multiple faces of the abostion are presented. This research does not intend to be conclusive in relation to the issues treated, but drawing attention, in a provocative way, to the others researchers can see in it an objective of interest, considering the social interactions that surround the theme. It is a relevant topic which others researchers from several areas of knowledge can add the results of their studies.
\end{abstract}

Key-words: Abortion, Biopower, Legislative Debate, National Congress, Sexual Rights and Reprodutives. 


\section{ABREVIATURAS}

A.D.P.F. - Arguição de Descumprimento de Preceito Fundamental

C. - Concordo

C.C.J.C. - Comissão de Constituição, Justiça e de Cidadania

C.E.D.A.W. - Convention on the Elimination of all Forms od Discrimination Against Women

C.E.P. - Concordo em Parte

C.I.P.D. - Conferência Internacional de População e Desenvolvimento

C.P. - Concordo Plenamente

C.R.F.B./88 - Constituição da República Federativa do Brasil em 1988

C.S.S.F - Comissão de Seguridade Social e Família

D. - Discordo

D.P. - Discordo Plenamente

D.S.R. - Direitos sexuais e reprodutivos

D.U.D.H. - Declaração Universal dos Direitos Humanos

H.I.V. - Human Immunodeficiency Virus

I.V.E. - Interrupción Voluntaria del Embarazo

M. S. - Ministério da Saúde

M.S.P. - Ministerio de Salud Pública

O.M.S. - Organização Mundial de Saúde

O.N.U. - Organizações das Nações Unidas

P.C. - Partido Colorado

P.C.do B. - Partido Comunista do Brasil

P.D.T. - Partido Democrático trabalhista 
P.F.A. - Partido Frente Amplio

P.I. - Partido Independiente

P.N. - Partido Nacional

P.N.A. - Pesquisa Nacional do Aborto

P.P. - Partido Progressista

P.R.B. - Partido Republicano Brasileiro

P.S.D. - Partido Social Democrático

P.S.D.B. - Partido da Social Democracia Brasileira

P.S.O.L. - Partido Socialismo e Liberdade

P.T.N. - Partido Trabalhista Nacional

S.T.F. - Supremo Tribunal Federal

S.U.S. - Sistema Único de Saúde

SINAdI - Sistema Nacional de Información 


\section{LISTA DE GRÁFICOS}

Gráfico 01 - População: Pesquisa Brasil..................................................79

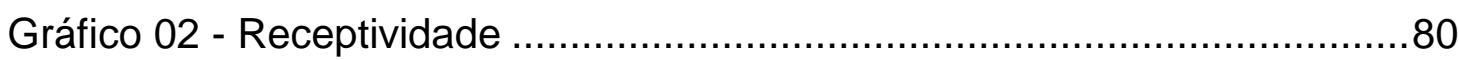

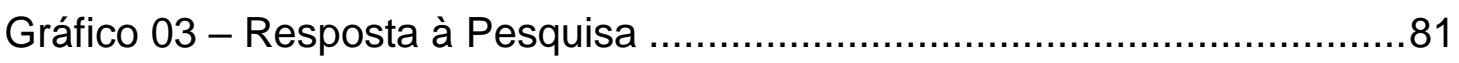

Gráfico 04 - Não Aceitaram Participar Devido a Polêmica.............................81

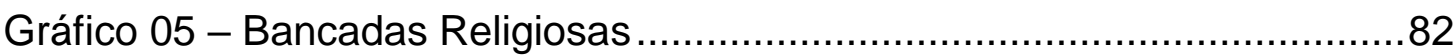

Gráfico 06 - Direitos Sexuais e Reprodutivos …………...........................83

Gráfico 07 - Pertence ao Estado o Biopoder................................................83

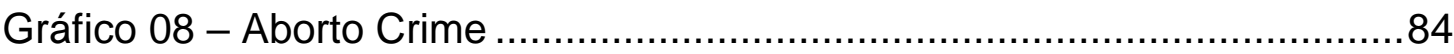

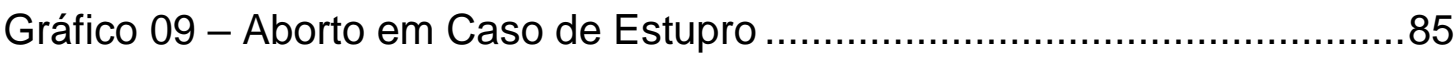

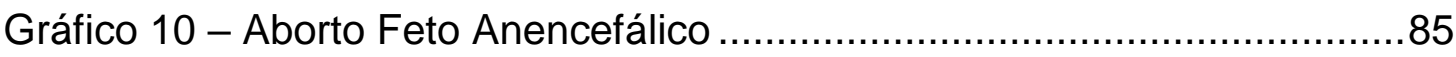

Gráfico 11 - Aborto em Caso de Risco na Gestação ....................................86

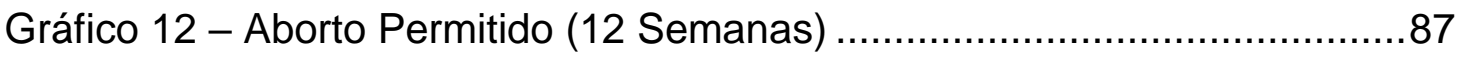

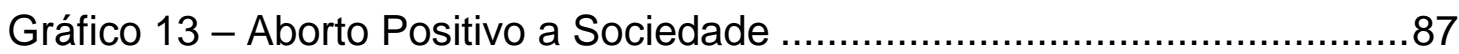

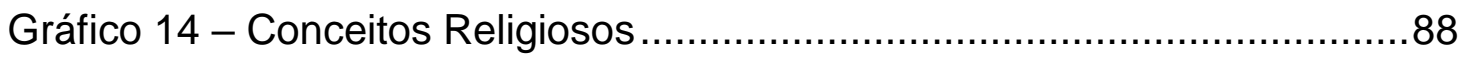

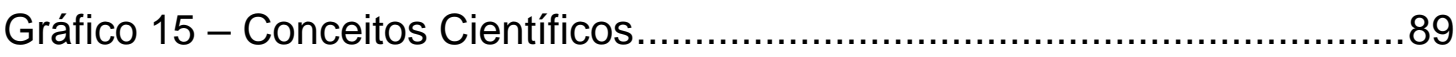

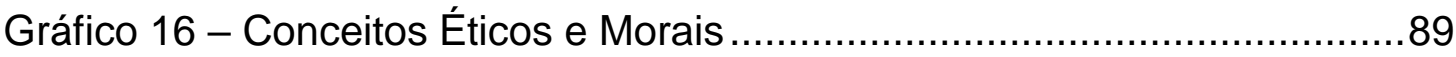

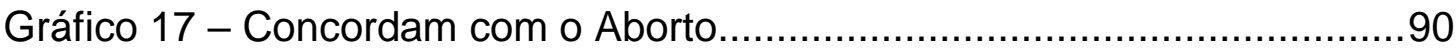

Gráfico 18 - Sexo

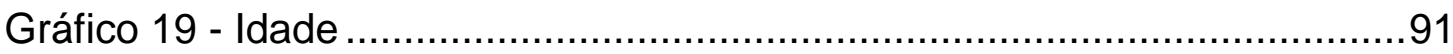

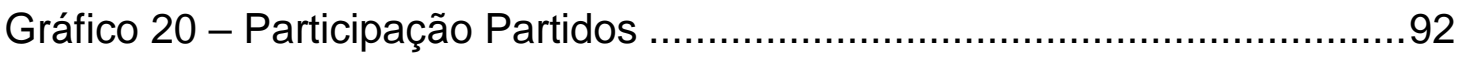

Gráfico 21 - Composição Câmara de Representantes Uruguai .......................94

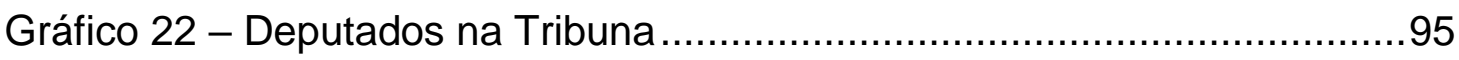

Gráfico 23 - Participação do Partido no Debate...........................................96

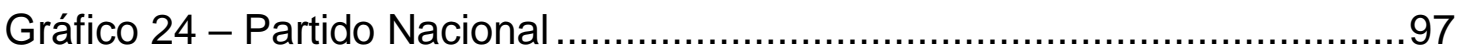




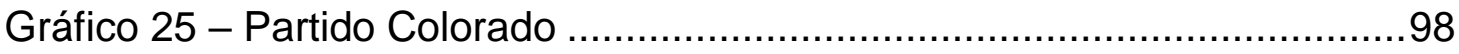

Gráfico 26 - Partido Independiente ...................................................99

Gráfico 27 - Partido Frente Amplio...................................................100

Gráfico 28 - Pontos Analisados........................................................ 100

Gráfico 29 - Utilização dos Pontos de Justificativa .................................101

Gráfico 30 - Relação Geral dos Temas .............................................102

Gráfico 31 - Votação Final ........................................................ 102

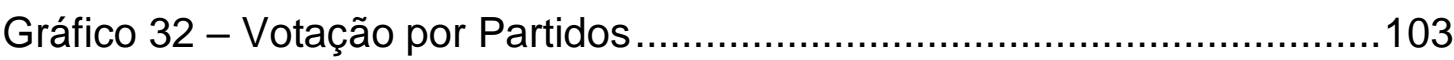


INTRODUÇÃO .....................................................................................14

CAPÍTULO I - DO ESTADO, PODER, BIOPODER E DOMINAÇÃO DO CORPO FEMININO. .17

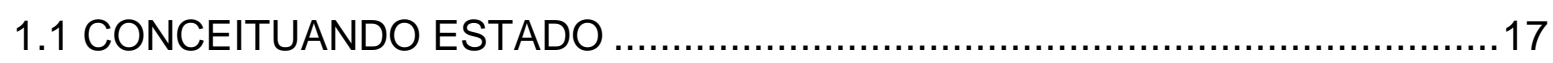

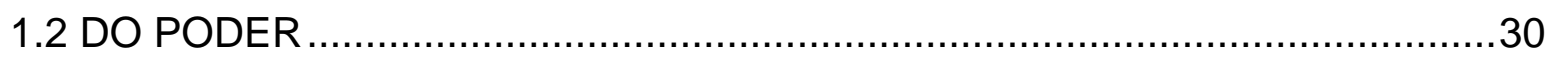

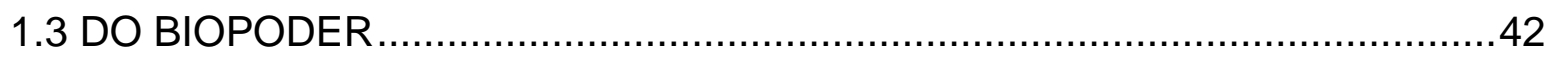

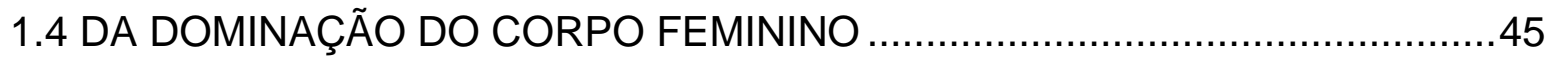

1.5 DIREITOS SEXUAIS E REPRODUTIVOS .................................................49

CAPÍTULO II - CONTEXTUALIZAÇÃO HISTÓRICA E EVOLUTIVA DO DEBATE BIOÉTICO A RESPEITO DO ABORTO NO BRASIL E NO URUGUAI ..................55

2.1 DEBATE SOBRE O ABORTO NO BRASIL ...............................................56

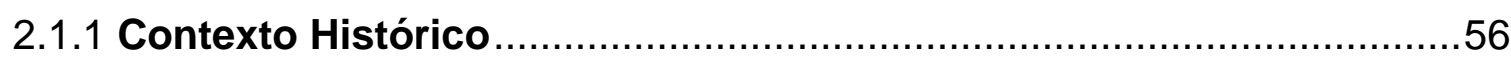

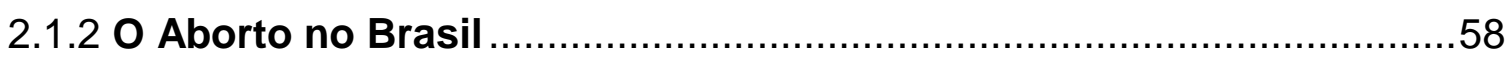

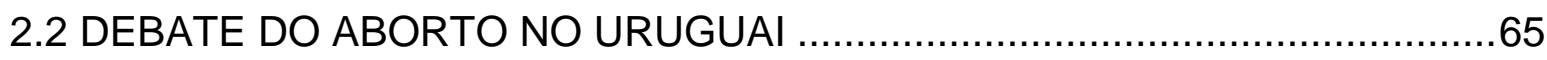

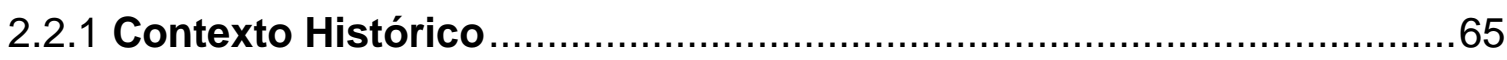

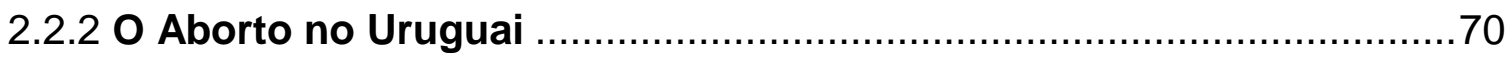

2.3 O ABORTO CLANDESTINO - MÉTODOS ..............................................70

CAPÍTULO III - METODOLOGIA E RESULTADOS DA PESQUISA .......................77

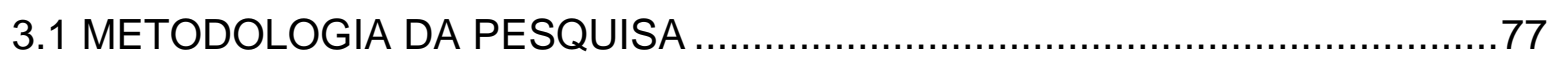

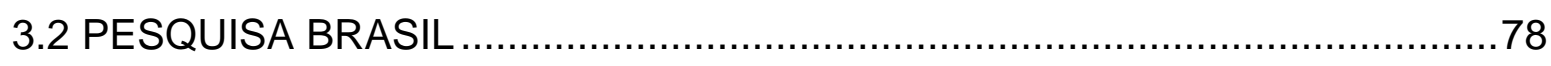

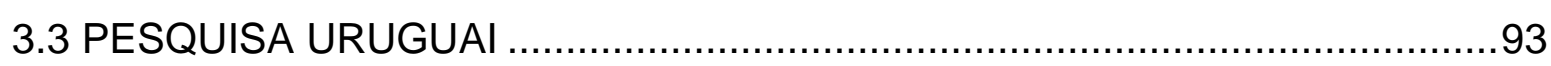

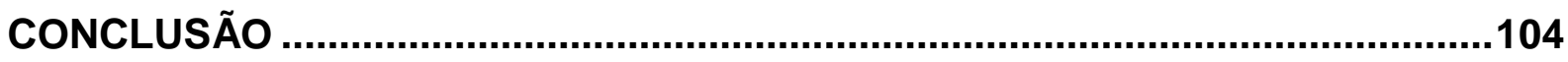

REFERÊNCIAS BIBLIOGRÁFICAS.........................................................108

ANEXOS I - PARECER COMITÊ DE ÉTICA EM PESQUISA UNIEURO ................118

ANEXO II - PROCESSOS E PROJETOS DE LEI COM TÓPICOS RELATIVOS AO ABORTO, MÉTODOS CONTRACEPTIVOS E TEMAS RELACIONADOS ATIVOS NA CÂMARA DOS DEPUTADOS - BRASIL 
ANEXO III - TERMO DE CONSENTIMENTO LIVRE E ESCLARECIDO - TCLE..121

ANEXO IV - QUESTIONÁRIO .123 


\section{INTRODUÇÃO}

A presente Dissertação realizou um estudo comparativo sobre a temática do Biopoder, a partir da atuação do Congresso Nacional Brasileiro e do Congresso Nacional Uruguaio, em especial, no que tange ao aborto, no contexto da bioética e de suas implicações. A pesquisa se desenvolveu na área de concentração Direitos Humanos, Cidadania e Violência, dentro da linha de pesquisa de Estado, Políticas Públicas e Cidadania, do Mestrado em Ciência Política do Centro Universitário UNIEURO. O projeto de pesquisa da presente dissertação foi aprovado pelo Comitê de Ética em Pesquisa do referido Centro universitário conforme parecer n 92/2016 (Anexo I).

Esta pesquisa, justificou-se, visto a dificuldade do Congresso Nacional Brasileiro em fazer frente a estas demandas do Biopoder, em especial, ao legislar sobre o aborto, fato em que difere da atuação do Congresso Nacional Uruguaio, que debateu e regulamentou o aborto, estruturando o sistema de saúde para atender ao procedimento. Apesar de tramitarem na Câmara dos Deputados inúmeros projetos de leis relacionados ao tema ${ }^{1}$, alguns ativos há mais de duas décadas e mesmo sendo o aborto, responsável pela morte de uma mulher brasileira a cada dois dias conforme afirma a Organização Mundial de Saúde (OMS) e representando a quinta causa de morte materna no país ${ }^{2}$, o Congresso Nacional brasileiro abstém-se do debate. Desta forma, mostrou-se relevante a pesquisa a fim de identificar, os fatores relativos ao tema, possibilitando, assim, o debate e a superação destes impedimentos.

Com base nesta justificativa, emergiu-se a seguinte questão: Como se deu o debate legislativo em torno do Biopoder, no que tange ao aborto, nos parlamentos do Brasil e do Uruguai, no Período democrático (1990 - 2017) nos dois países?

Estabeleceu-se, portanto, a seguinte hipótese: Devido a questões de ordem social, política e cultural, o Congresso Nacional brasileiro possui intensa dificuldade

\footnotetext{
${ }^{1}$ MACHADO, Gustavo Silveira. Projetos de lei sobre aborto em tramitação na Câmara dos Deputados. 2007. Disponível em: <http://bd.camara.leg.br/bd/handle/bdcamara/1437>. Acesso em: 23 jun. 2016. $10 \mathrm{~h} 40$.

2 GRANJEIA, Julianna. Governo afirma à ONU que aborto clandestino no país é problema de saúde pública. 2015. Disponível em: < http://oglobo.globo.com/sociedade/governo-afirma-onu-que-abortoclandestino-no-pais-problema-de-saude-publica-15550664>. Acesso em: 23 jun. 2016. 11 h01.
} 
em debater e legislar temas que firam susceptibilidades de ordem moral e/ou ética e que sejam objeto de qualquer tipo de controvérsia, como o que ocorre com o aborto.

Tema de fundamental importância na sociedade brasileira, o aborto foi regularizado no ano de 2012 no Uruguai, mas seu debate ainda encontra resistências no Parlamento brasileiro, que passa a praticar, uma política de abstenção acerca de debates tidos como polêmicos. O foco da pesquisa manteve-se na atuação no Congresso Nacional do Brasil, comparado ao Congresso Nacional do Uruguai, no que tange ao Biopoder, em especial, ao debate acerca do aborto. O estudo analisa o desempenho de ambos parlamentos, no período democrático (1990-2017).

A presente dissertação teve como objetivo geral descrever o debate legislativo em torno do Biopoder, acerca do aborto nos parlamentos do Brasil e do Uruguai, no período democrático (1990-2017) e como objetivos específicos: (i) Desenvolver o marco teórico-conceitual da formulação do termo biopoder e sua aplicação junto ao Estado; (ii) Contextualizar, histórica e evolutivamente, o debate bioético a respeito do aborto no Brasil e no Uruguai, apresentando a atual situação; (iii) Analisar a atuação do Congresso Nacional Uruguaio durante o debate da lei do aborto, comparando-a, posteriormente, a atual situação no Congresso Nacional Brasileiro (2017).

Para a realização desta dissertação foi utilizado um estudo bibliográfico, qualitativo, de natureza analítica e indutiva, no que diz respeito ao Biopoder e sua atuação nos parlamentos Brasileiro e Uruguaio, assim como, a análise do procedimento legislativo em ambos os parlamentos. Identificaram-se os grupos de interesse nas políticas públicas, verificando como se agrupam, como se relacionam entre si e como influenciam em decisões.

Foi realizada uma pesquisa de campo, com um questionário, dentro do congresso brasileiro, com o objetivo de identificar fatores relativos ao tema Biopoder, principalmente, em relação ao aborto. Os dados referentes ao Uruguai, foram obtidos por meio de pesquisa bibliográfica, realizada no banco de dados do Parlamento uruguaio, tendo como base as atas do processo de votação e debate, da lei do aborto (Disponíveis no site do parlamento uruguaio).

Assim, estruturalmente, o trabalho está dividido em três capítulos, tratando o primeiro capítulo do Estado, Poder e Biopoder, conceituando incialmente estes termos e tratando por fim, a respeito da dominação do corpo feminino. Este Capítulo 
foi estruturado utilizando conceitos apresentados por Habermas, Foucault, Arendt, Bobbio e Agambem, entre outros.

No capítulo II, procurou-se contextualizar, histórica e evolutivamente, a atuação dos Congressos Brasileiro e Uruguaio no que tange ao tema bioético aborto, apresentando a evolução do debate legislativo em ambos os parlamentos. Apresentando no final do capítulo os principais métodos utilizados para a realização do procedimento do aborto e por fim, a evolução dos Direitos Sexuais e Reprodutivos. Os principais autores utilizados para a construção deste capítulo foram: Rocha, Diniz, Loyola, Galli, Machado, entre outros autores, além de textos legislativos.

No Capítulo III é apresentada a metodologia utilizada no trabalho e são apresentados os dados obtidos durante a pesquisa. Com intento de explicar e entender melhor a atitude de ambos os parlamentos em relação ao aborto, são apresentados gráficos que demonstram os resultados.

Por último é apresentada a conclusão. Nesta são analisados os gráficos apresentados no capítulo anterior, comprovando, com isto, a hipótese apresentada incialmente de que é praticada uma certa abstenção aos debates bioéticos no Congresso Nacional Brasileiro. 


\section{CAPÍTULO I - DO ESTADO, PODER, BIOPODER E DOMINAÇÃO DO CORPO FEMININO}

Este capítulo tem como finalidade apresentar o marco teórico vinculado à pesquisa, apresentando os conceitos básicos referentes ao Estado, Poder, Biopoder, e o controle do Estado sobre o corpo, especialmente o feminino.

\subsection{CONCEITUANDO ESTADO}

Neste subcapítulo, apresentaremos os principais conceitos relativos ao estado e a sua função na sociedade moderna.

No princípio tudo era nada, e nada no princípio havia. Porém, com a necessidade tudo se criou, e do nada tudo existiu. Era necessário agora organizar tudo, e então, no princípio surgiu a sociedade.

A sociedade, possui como característica central ser uma coletividade organizada formada por pessoas que interagem. Suas atividades se centralizam visando o bem comum com base em crenças e modos de ação comuns ${ }^{1}$. A palavra "sociedade" tem origem no latim societas, e possui o significado de "associação amistosa com outros"2. Existindo desde os primórdios da humanidade, sua forma de organização sofreu diversas alterações ao longo da história. A sociedade do homem pré-histórico estava organizada de forma hierárquica, em que um chefe (geralmente o mais forte ou sábio do grupo) era o detentor do poder. Durante o período da Grécia Antiga, a tendência absolutista do poder começou a variar, visto que, as classes inferiores da sociedade puderam chegar a certos setores de destaques na tomada de decisões através da democracia ${ }^{3}$.

\footnotetext{
1 KRECH, David; CRUTCHFIELD, Richard S.; BALLACHEY, Egerton L.. O Indivíduo na Sociedade: Um Manual de Psicologia Social. São Paulo: Editora da Universidade de São Paulo, 1962. 656 p. 2 v. Tradução de Dante Moreira Leite e Miriam L. Moreira Leite.

2 CAMARGO, Orson. "Sociedade"; Brasil Escola. Disponível em <http://brasilescola.uol.com.br/sociolo gia/sociedade-1.htm >. Acesso em 20 de junho de 2017.

3 CONCEITO. Conceito de sociedade - O que é, Definição e Significado. 2016. Disponível em: <http://co nceito.de/sociedade>. Acesso em: 10 mar. 2016.
} 
Dallari afirmou que,

Numa visão genérica do desenrolar da vida do homem sobre a Terra, desde os tempos mais remotos até nossos dias, verificamos que, à medida em que se desenvolveram os meios de controle e aproveitamento da natureza, com a descoberta, a invenção e o aperfeiçoamento de instrumentos de trabalho e de defesa, a sociedade simples foi-se tornando cada vez mais complexa. Grupos foram-se constituindo dentro da sociedade, para executar tarefas específicas, chegando-se a um pluralismo social extremamente complexo. ${ }^{4}$

O surgimento da sociedade está na gênese da formação do Estado, sendo este, criado pela necessidade de solucionar conflitos e organizar-se de melhor forma em prol da coletividade. A relação entre sociedade e Estado, no sistema democrático, dá-se por intermédio de representantes políticos eleitos pelo povo para defender seus interesses junto ao Estado. Em linhas gerais, tem-se, portanto, o povo que forma a sociedade e a sociedade que forma o Estado que trabalha, por sua vez, em prol de sua manutenção e bem-estar de sua população. Locke afirmava que,

Tendo Deus feito do homem uma criatura tal que, segundo seu julgamento, não era bom para ele ficar sozinho, submeteu-o a fortes obrigações de necessidade, comodidade e inclinação para levá-lo a viver em sociedade, assim como o dotou de entendimento e linguagem para mantê-la e desfrutála. ${ }^{5}$

Hobbes, argumentava contra o entendimento da doutrina de Santo Agostinho e São Tomás de Aquino, de que tudo, inclusive o Estado, fora criado por Deus. Desta forma, o Estado não se originava do homem, da sociedade e da ordem, mas sim de uma figura maior. Defendia que, sem poder e sem organização o homem viveria em um estágio denominado por ele de "estado de natureza", o qual representava uma condição de guerra. Propõe então que, para evitar a guerra, haveria a necessidade da criação do Estado, para controlar e reprimir o homem que ainda vive em estado de natureza. Desta forma, aos olhos do autor, a paz seria apenas

4 DALLARI, Dalmo de Abreu. Elementos de teoria geral do estado. 30. ed. São Paulo: Saraiva, 2011, p. 31.

${ }^{5}$ LOCKE, John. Segundo Tradado sobre o Governo Civil e Outros Escritos. 3 ed. Petrópolis: Vozes, 2001, p. 129 
possível, se o homem fosse supervisionado pelo ente estatal, legitimado por um contrato social ${ }^{6}$

Em referência ao contrato social, Rousseau afirmou que o seu objetivo seria,

encontrar uma forma de associação que defenda e proteja a pessoa e os bens de cada associação de qualquer força comum, e pela qual, cada um, unindo-se a todos, não obedeça, portanto, senão a si mesmo, ficando assim tão livre como dantes ${ }^{7}$

Compreende-se, portanto, o Estado como sendo o aglutinamento de indivíduos, por intermédio do contrato social, objetivando o bem comum. A este respeito, afirmava Immanuel Kant que,

\begin{abstract}
$O$ ato pela qual um povo se constitui num Estado é o contrato original. A se expressar rigorosamente, o contrato original é somente a idéia desse ato, com referência ao qual exclusivamente podemos pensar na legitimidade de um Estado. De acordo com o contrato original, todos (omnes et singuli) no seio de um povo renunciam à sua liberdade externa para reassumi-la imediatamente como membros de uma coisa pública, ou seja, de um povo considerado como um Estado (universI). E não se pode dizer: o ser humano num Estado sacrificou uma parte de sua liberdade externa inata a favor de um fim, mas, ao contrário, que ele renunciou inteiramente à sua liberdade selvagem e sem lei para se ver com sua liberdade toda não reduzida numa dependência às leis, ou seja, numa condição jurídica, uma vez que esta dependência surge de sua própria vontade legisladora ${ }^{8}$
\end{abstract}

No âmbito da ciência política, o conceito de Estado torna-se algo de difícil definição para os recém-chegados ao seu estudo, confundindo-se facilmente com governo, estado-nação ou país, e em outros casos com sistema econômico e regime político.

Para Engels, o Estado surge da dissolução da comunidade humana primitiva e da divisão da sociedade em classes. Observa assim que,

${ }^{6}$ HOBBES, Thomas. Leviatã ou matéria, forma e poder de um Estado eclesiástico e civil. São Paulo: Martin Claret, 2009, p. 143.

7 ROUSSEAU, Jean-Jacques. O Contrato Social. Rio de Janeiro: Tecnoprint, 1762, p.35.

8 KANT. Immanuel. A Fundamentação da Metafísica dos Costumes. A Doutrina Universal do Direito, p. 158. 
O Estado não é pois, de modo algum, um poder que se impõe à sociedade de fora para dentro; tampouco é a 'realidade da ideia moral', nem 'a imagem e a realidade da razão' como afirma Hegel. É, antes, um produto da sociedade quando esta chega a determinado grau de desenvolvimento; é a confissão de que essa sociedade se enredou numa irremediável contradição com ela própria e está dividida por antagonismos irreconciliáveis que não consegue conjurar. Mas para esses antagonismos, essas classes com interesses econômicos colidentes não se devorem e não consumam a sociedade em uma luta estéril, faz-se necessário um poder colocado acima da sociedade, chamado a amortecer o choque e a mantê-lo dentro dos limites da 'ordem'. Este poder, nascido da sociedade, mas posto acima dela, e dela se distanciando cada vez mais, é o Estado ${ }^{9}$

Engels nesse trabalho, resume a origem do Estado e, concomitantemente conceitua-o a partir de um ponto de vista histórico. Trata-se de um poder, ou seja, uma estrutura organizacional e política que emerge da progressiva complexificação da sociedade e da sua divisão em classes destinadas a manter a ordem dentro da sociedade.

Dallari, sintetiza em três posicionamentos básicos as diversas teorias relativas ao momento do surgimento do Estado ${ }^{10}$. Estes são obtidos por intermédio de análises antropológicas, filosóficas e jurídicas.

O primeiro posicionamento estabelecido por Dallari ${ }^{11}$, se inicia com o entendimento de que o Estado, assim como a sociedade sempre existiu. Desde os primórdios da evolução do homem na terra, este sempre se manteve ligado a uma organização social, que por sua vez, era dotada de poder e capaz de determinar o comportamento social do grupo.

Continuando a análise de Dallari ${ }^{12}$, em seu segundo posicionamento ele afirma que a sociedade humana existiu, em algum momento histórico, sem o Estado, porém, conforme sua evolução fora exigida certa organização. Assim, o Estado, com o passar dos tempos, foi surgindo, tendo como finalidade atender as necessidades do

${ }^{9}$ ENGELS, Friedrich. The Origin of Family, Private Property and the state. Nova York: International Publishers. First German edition. 1884. K. Marx na F. Engels, selected Words. Moscou: Progress Publisher. 1993. p. 326-327.

${ }^{10}$ DALLARI, Dalmo de Abreu. Elementos de teoria geral do estado. 30. ed. São Paulo: Saraiva, 2011, p. 60 .

11 Ibidem.

12 Ibidem. 
grupo social. Desta forma, o surgimento do Estado está ligado a uma necessidade da sociedade, ou seja, a sociedade o precede.

O último posicionamento de Dallari afirma que o conceito de Estado evolui a cada nova era ${ }^{13}$. Conforme estabelece Soares, citando Schmitt, este ponto nasceu da ideia de doutrinadores que admitem o Estado,

Como sociedade política dotada de certas características bem definidas. Nesse sentido, para Schmitt, o conceito de Estado não é conceito geral válido para todos os tempos, mas conceito histórico concreto surgido quando nasceu a idéia e a prática de soberania ${ }^{14}$

Assim, conforme Dallari, verifica-se que o surgimento do Estado, acaba implicando em duas indagações, sendo que, a primeira diz respeito à época do seu aparecimento e, a segundo aos motivos os quais, determinaram e ainda determinam a sua existência ${ }^{15}$.

Conforme esclarece o autor, a denominação do Estado vem do latim,

Estado (do latim status = estar firme), significando situação permanente de convivência e ligada a sociedade política, aparece pela primeira vez em ' $O$ Príncipe' de Maquiavel, escrito em 1513, passando a ser usada pelos italianos sempre ligada ao nome de uma cidade independente, como, por exemplo stato di Firenze. Durante os séculos XVI e XVII a expressão foi sendo admitida em escritos franceses, ingleses e alemães. Na Espanha, até o século XVIII, aplicava-se também a denominação de estados a grandes propriedades rurais de domino particular, cujos proprietários tinham poder jurisdicional. De qualquer forma, é certo que o nome Estado, indicando uma sociedade política, só aparece no século XVI, e este é um dos argumentos para alguns autores que não admitem a existência do Estado antes do século XVI. Para eles, entretanto, sua tese não se reduz a uma questão de nome, sendo mais importante o argumento de que o no Estado só pode ser aplicado com propriedade à sociedade política dotada de certas características bem definidas. A maioria dos autores, no entanto, admitindo que a sociedade os denominada Estado é, na sua essência, igual à que existiu anteriormente, embora com nomes diversos, dá essa designação a todas as sociedades políticas que, com autoridade superior, fixaram as regras de convivência de seus membros ${ }^{16}$.

${ }^{13}$ DALLARI, Dalmo de Abreu. Elementos de teoria geral do estado. 30. ed. São Paulo: Saraiva, 2011, p. 60.

${ }^{14}$ SOARES, Mário Lúcio Quintão. Teoria do Estado. 2 ed. Ver. Atual. Belo Horizonte: Del Rey, 2004, p. 80.

${ }^{15}$ DALLARI, Dalmo de Abreu. Elementos de teoria geral do estado. 30. ed. São Paulo: Saraiva, 2011, p. 59.

${ }^{16}$ Ibidem., p. 59. 
O conceito de Estado é formado por vários elementos. Para se entender este conceito é preciso observar seus paradigmas e suas mudanças no decorrer da história, criando, à limiar dos direitos fundamentais, uma reflexão a respeito da gênese do Estado moderno, analisando suas transformações, os seus elementos constitutivos e a diluição de seus conceitos clássicos.

Hegel citado por Soares,

Define o Estado como totalidade ética: a realidade da ideia ética o espírito ético enquanto vontade patente, evidente por si mesma, substancial, que pensa e conhece de si mesma, que cumpre o que sabe e como sabe ${ }^{17}$

Soares, no desenvolver de seu trabalho, apresenta a definição de Jellinek, que apresenta "o Estado juridicamente como a corporação de um povo, assente em um determinado território e dotada de um poder originário de mando"18. Já Kelsen afirma que "O Estado é uma sociedade politicamente organizada porque é uma comunidade constituída por uma ordem coercitiva [...]"19

Ao aprofundar seu trabalho, imergindo dentro do paradigma do Estado social de direito, Soares busca em Heller o entendimento de que o Estado é,

Uma unidade de dominação territorial soberana, diferenciando-se dos demais grupos territoriais de dominação por seu caráter de unidade soberana de ação e decisão. O Estado sobrepõe-se às demais unidades do poder existentes em seu território pelo fato de poderem os órgãos estatais capacitados reclamar, com êxito normal, a aplicação, a eles exclusivamente reservada, do poder físico coativo, e também por que estão em condições de executar as suas decisões, dando-se o caso, perante a quem a elas se opuser, por meio de todo poder físico coativo da organização estatal atualizado de maneira unitária. ${ }^{20}$

17HEGEL, apud, SOARES, Mário Lúcio Quintão. Teoria do Estado. 2 ed. Ver. Atual. Belo Horizonte: Del Rey, 2004, p. 93.

18 Ibidem. JELLINEK apud SOARES. 2004, p. 93.

19 KELSEN, Hans. Teoria geral do direito e do estado. Tradução: Luis Carlos Borges. 3 ed. São Paulo: Martins Fontes, 2000, p. 273.

${ }^{20}$ HELLER, apud, SOARES, Mário Lúcio Quintão. Teoria do Estado. 2 ed. Ver. Atual. Belo Horizonte: Del Rey, 2004, p.94. 
Dentro da concepção de Vedel, "o Estado caracteriza-se pelo fato de seus governantes deterem o monopólio da força armada e se submeterem aos mecanismos da institucionalização do poder"21

A concepção de Estado atual antes compreende, segundo Hesse ${ }^{22}$ observar que o Estado descobriu a historicidade de seu objeto e a sua própria historicidade. É em razão disto que o Estado está sempre evoluindo, conforme a necessidade organizacional da sociedade,

O Estado não pode ser mais concebido como unidade determinada, substancialmente imutável, situada do outro lado das forças históricas reais, pois o desenvolvimento industrial moderno e as alterações produzidas por ele inadmitem desconsiderar o problema da formação da unidade política e isolar o Estado de seu substrato sociológico. ${ }^{23}$

\section{Conceituando Estado, Silva esclarece que}

Estado é, na justa definição de Balladore Pallieri, uma ordenação que se tem por fim específico e essencial à regulamentação global das relações sociais entre os membros de uma dada população sobre um dado território, na qual a palavra ordenação expressa a idéia de poder soberano, institucionalizado. O Estado, como se nota, constitui-se de quatro elementos essenciais: um poder soberano de um povo situado num território com certas finalidades. $\mathrm{E}$ a constituição, como dissemos antes, é o conjunto de normas que organizam estes elementos constitutivos do Estado: povo, território, poder e fins. ${ }^{24}$

Hans Kelsen, em seus estudos, tende a negar a realidade social, analisando o Estado pela ótica de realidade jurídica, afirmando que este é "uma pessoa jurídica, ou seja, como uma corporação"25, da mesma forma, Duguit (Apud

21 VEDEL apud, SOARES, Mário Lúcio Quintão. Teoria do Estado. 2 ed. Ver. Atual. Belo Horizonte: Del Rey, 2004, p. 94.

22 HESSE, apud, SOARES, Mário Lúcio Quintão. Teoria do Estado. 2 ed. Ver. Atual. Belo Horizonte: Del Rey, 2004, p.94.

23 Ibidem.

${ }^{24}$ SILVA, José Afonso. Curso de Direito Constitucional Positivo. 25 ed. Revista e atualizada nos termos da Reforma Constitucional, até a Emenda Constitucional n. 48, de 10.8.2005. São Paulo: Malheiros Editores LTDA., 2005, p. 97.

${ }^{25}$ KELSEN, Hans. Teoria geral do direito e do estado. Tradução: Luis Carlos Borges. 3 ed. São Paulo: Martins Fontes, 2000, p. 183. 
Maluf) estabelece que o Estado é uma "criação exclusiva da ordem jurídica e representa uma organização da força a serviço do direito"26

Em seus estudos, Alexandre Groppali, ao trabalhar o conceito de Estado, estabeleceu que

O Estado inegavelmente, significa o domínio dos mais fortes e organiza os serviços públicos, mas seria revelar um conceito unilateral da realidade, o de não se admitir que é no interesse da coletividade também que esse domínio é exercido e que o Estado, além dos serviços públicos, deve visar outros fins mais altos, de natureza ética e social, que perduram no tempo, se não quer transformar-se, degradando-se, em um mero órgão técnico de administração 27

Atualmente, a concepção que se tem de Estado é na verdade uma evolução gradual dos princípios contratualistas de Hobbes, Locke e Rousseau, visto que, através da adesão ao contrato social, o homem concedeu o Estado como algo artificial, como uma construção racional que se fez necessária em dado momento histórico. Desta forma, verifica-se o fim do Estado Natural e o início do Estado Civil política e socialmente organizado.

Tem-se como contrato social, nos termos estabelecidos, o pacto que dá origem ao Estado Civil. Constitui-se, porém, que há uma diferenciação na forma de apresentação da organização estatal da sociedade. Em Hobbes observamos o poder absoluto do Estado ${ }^{28}$. Em contraponto a Locke verificamos o liberalismo e em Rousseau temos a democracia.

Em prol da comunidade ${ }^{29}$, o homem elabora pactos e contratos sociais visando assim, transferir direitos naturais (renúncia) em proveito do interesse público.

Com extrema clareza, Tobias Barreto conceitua o bem comum

\footnotetext{
${ }^{26}$ MALUF, Sahid. Teoria Geral do Estado. 24 ed. rev. atual. São Paulo: Saraiva, 1998, p. 20.

27 GROPPALI, Alexandre. Doutrina do Estado. Tradução Paulo Edmur de Souza Queiroz. 2 ed. São Paulo: Saraiva. 1962, p. 264-265.

28 Utilizado por alguns autores para defender o absolutismo.

${ }^{29}$ Segundo Ferdinand Tonnies, a comunidade é uma forma social que se caracteriza, e é constituída, pelas relações pessoais, costumes, religião, cooperação e forte espírito emocional, sendo encontrada na família, aldeias e em pequenas comunidades urbanas. A comunidade é a união em prol da sua conservação. Para maiores informações ler TONNIES, F. Comunidad y Sociedad. Buenos Aires: Losada. 1947.
} 
O fim do Estado é um facto que a cada momento se realisa na sociedade e que a cada momento está para ser realisado. Sempre se realisou e nunca acaba de se realisar. É um acto interminavelmente repetindo-se, incessantemente renovando-se. Todas as vezes que a lei penal pune aquelle que se poz em conflicto contra a ordem publica, offendendo direitos de terceiro, está se realisando o fim do Estado. Todas as vezes que o cidadão que trabalha gosa pacificamente dos proventos do seu trabalho, e o cidadão que estuda gosa dos fructos de suas vigílias, de suas indagações, á sombra da lei, o fim do Estado está se realisando. A honra protegida contra os ataques da injuria, da calumnia, e do ímpeto carnal: a vida do cidadão inviolavel, sua propriedade garantida contra o roubo, o furto, o esbulho, etc: o exercicio, em summa, de todos os direitos afiançados pelos poderes publicos: tal é o fim do Estado.(Conforme o Original) ${ }^{30}$

$\mathrm{O}$ ato de realizar contratos sociais dentro de determinado grupo, é o que possibilitou o surgimento do Estado, gerando assim, força e capacidade de proteção. Conforme estabelecia John Locke,

Os homens são por sua natureza livres, iguais e independentes, e por isso ninguém pode ser expulso de sua propriedade e submetido ao poder político de outrem sem dar seu consentimento. O único modo legítimo pelo qual alguém abre mão de sua liberdade natural e assume os laços da sociedade civil consiste no acordo com outras pessoas para se juntar e unir-se em comunidade, para viverem com segurança, conforto e paz umas com as outras, com a garantia de gozar de suas posses, e de maior proteção contra quem não faça parte dela ${ }^{31}$

Sendo assim, os homens que se uniram com o intuito de formarem uma sociedade, abdicavam, desta forma, de uma parcela de sua liberdade natural, sem autorizar que as regras seriam impostas unicamente por um soberano, mas sim, por intermédio de um pacto social, acabando assim, com a indivisibilidade do estado proposta por Hobbes. ${ }^{32}$

Nesta mesma linha de raciocínio, Kant estabelece que

$O$ ato pela qual um povo se constitui num Estado é o contrato original. A se expressar rigorosamente, o contrato original é somente a idéia desse ato,

30 TOBIAS, Barreto. Prelecções de direito constitucional - Estudos de Direito. vol. II, Sergipe: E.C.E., 1926, p. 49.

31 LOCKE, John. Segundo Tradado sobre o Governo Civil e Outros Escritos. 3 ed. Petrópolis: Vozes, 2001, p. 76.

${ }^{32}$ HOBBES, Thomas. Leviatã ou matéria, forma e poder de um Estado eclesiástico e civil. São Paulo: Martin Claret, 2003, p. 102. 
com referência ao qual exclusivamente podemos pensar na legitimidade de um Estado. De acordo com o contrato original, todos (omnes et singuli) no seio de um povo renunciam à sua liberdade externa para reassumi-la imediatamente como membros de uma coisa pública, ou seja, de um povo considerado como um Estado (universi). E não se pode dizer: o ser humano num Estado sacrificou uma parte de sua liberdade externa inata a favor de um fim, mas, ao contrário, que ele renunciou inteiramente à sua liberdade selvagem e sem lei para se ver com sua liberdade toda não reduzida numa dependência às leis, ou seja, numa condição jurídica, uma vez que esta dependência surge de sua própria vontade legisladora ${ }^{33}$

Seguindo neste prisma, Habermas estabelece que, "uma ordem jurídica só pode ser legítima quando não contrariar os princípios morais"34. Desta forma, baseando-se nos elementos da legitimidade da validade jurídica, é que o direito se relaciona com a moral de forma reciprocamente complementar.

Segundo o autor, "em questões morais, a humanidade ou uma suposta república dos cidadãos forma o sistema de referência para a fundamentação de regulamentações que são do interesse simétrico de todos" 35 , diferenciando-se de questões ético-políticas em que o sistema de referência utilizado para a fundamentação de regulamentações valessem como expressões de um auto entendimento coletivo consciente.

Os direitos subjetivos, para Habermas ${ }^{36}$, através do nexo interno do direito com o poder político, apenas podem ser estatuídos e impostos, por intermédio de organismos que tomam decisões, as quais, passam a ser obrigatórias para a coletividade. Neste ponto, surge o Estado como uma instância central autorizada a agir em nome do todo, surgindo, portanto, como organização capaz de aplicar sanções legitimamente, utilizando a coerção para que as normas jurídicas por ele instituídas sejam respeitadas.

Para garantir esta ação, o Estado utiliza-se de "sua capacidade para a organização e auto-organização destinada a manter, tanto para fora como para dentro, a identidade da convivência juridicamente organizada" ${ }^{37}$.

${ }^{33}$ KANT, Immanuel. A Fundamentação da Metafísica dos Costumes. A Doutrina Universal do Direito, p. 158

${ }_{34}$ HABERMAS, Jürgen. Direito e democracia: entre a facticidade e a validade. Vol. 1, traduzido por

Flávio Beno Siebeneichler, Rio de Janeiro: Tempo Brasileiro, 1997, p. 141.

35 Ibidem. p. 142.

36 Ibidem.

${ }^{37}$ Ibidem. p. 170. 
Conforme estabelece 0 autor, os direitos fundamentais, os processos legislativos democráticos, como também a formação da vontade política organizada na forma do legislativo, é dependente de uma estrutura estatal que se transforma em uma instituição para o exercício efetivo e burocrático da dominação legal.

Habermas resume isto, dizendo que

O Estado é necessário como poder de organização, de sanção e de execução, porque os direitos têm que ser implantados, porque a comunidade de direito necessita de uma jurisdição organizada e de uma força para estabilizar a identidade, porque a formação da vontade política cria programas que têm que ser implementados. Tais aspectos não constituem meros complementos, funcionalmente necessários para o sistema de direitos, e sim, implicações jurídicas objetivas, contidas in nuce nos direitos subjetivos. Pois o poder organizado politicamente não se achega ao direito como que a partir de fora, uma vez que é pressuposto por ele: ele mesmo se estabelece em formas do direito. O poder político só pode desenvolver-se através de um código jurídico institucionalizado na forma de direitos fundamentais. ${ }^{38}$

A ideia de Estado de Direito remete a duas faces, sendo que, a primeira se refere à exigência de que as decisões estatais não revistam apenas a forma do direito e a segunda, apresenta-nos a necessidade de que essas decisões se legitimem pelo direito corretamente estatuído. O que valida efetivamente o exercício do poder político é a sua ligação com o direito legitimamente estabelecido ${ }^{39}$.

Segundo o Jurista e filósofo alemão Herman Heller, é imprescindível dizer que

Para se compreender o que chegou a ser o Estado atual, não é preciso buscar seus antecessores em tempos remotos, quando até a época primitiva da humanidade; sempre que se procurou fazer tal coisa, desatendeu-se, em geral aquilo que ao nosso objetivo principalmente interessa: a consciência histórico, absolutamente peculiar e que, nesta sua moderna individualidade, não pode ser translada aos tempos passados ${ }^{40}$

38 HABERMAS, Jürgen. Direito e democracia: entre a facticidade e a validade. Vol. 1, traduzido por Flávio Beno Siebeneichler, Rio de Janeiro: Tempo Brasileiro, 1997, p. 171.

39 Ibidem.

${ }^{40}$ HELLER, Herman. Saatslehre. 6. Ed. Tubingen: Mohr Siebeck. 1983, p. 157. 
O Estado Democrático de Direito da forma pela qual é conhecido atualmente, é uma decorrência de um extenso processo de evolução da forma como as sociedades foram se organizando no decorrer dos séculos.

Pode-se, assim, concluir que, o Estado Democrático de Direito é qualquer Estado que se aplique a garantir o respeito às liberdades civis, ou seja, o respeito às garantias fundamentais e aos direitos humanos, utilizando para isto o estabelecimento de uma proteção jurídica. Em um Estado de Direito, os próprios representantes políticos estão sujeitos ao respeito das regras de direito.

O Estado de Direito possui fundamental importância no desenvolvimento das sociedades modernas, após um extenso processo de afirmação dos direitos humanos, sendo este, um de seus fundamentos essenciais para a organização das sociedades políticas do mundo contemporâneo.

O Estado Democrático de Direito surge como um farol a iluminar o caminho para a solução da maioria dos problemas e tensões enfrentados pelas sociedades modernas.

Conforme afirma Bolzan de Morais, o Estado Democrático de Direito

Tem um conteúdo transformador da realidade, não se restringindo, como o Estado Social de Direito, a uma adaptação melhorada das condições sociais de existência. Assim, o seu conteúdo ultrapassa o aspecto material de concretização de uma vida digna ao homem e, passa a agir simbolicamente como fomentador da participação pública quando o democrático qualifica o Estado, que irradia os valores da democracia sobre os seus elementos constitutivos e, pois, também sobre a ordem jurídica ${ }^{41}$.

Neste mesmo seguimento, a respeito do Estado Democrático, José Afonso da Silva afirma que,

Este se funda no princípio da soberania popular, que 'impõe a participação efetiva e operante do povo na coisa pública, participação que não se exaure, como veremos, na simples formação das instituições representativas, que constituem um estágio da evolução do Estado Democrático, mas não seu

${ }^{41}$ BOLZAN DE MORAIS, José Luis. Do Direito Social aos Interesses Transindividuais. O Estado e

o Direito na Ordem Contemporânea, Porto Alegre: Livraria do Advogado, 1996, p. 74. 
completo desenvolvimento'. Visa, assim, a realizar o princípio democrático como garantia geral dos direitos fundamentais da pessoa humana ${ }^{42}$

O objetivo do Estado Democrático de Direito, segundo Elías Díaz, é transformar em realidade as exigências, do contrato da sociedade. A seu juízo, o Estado democrático, para não se tornar um totalitarismo "democrático", é preciso se tornar um Estado Democrático de Direito. ${ }^{43}$

Desta forma afirma que,

\begin{abstract}
Sendo a democracia modo de exercício do poder, é processo, o que significa que a técnica pela qual o poder, advindo da vontade popular, é exercido, deve coadunar-se aos procedimentos preestabelecidos mediante leis elaboradas por representantes eleitos, isto é, deve obedecer ao princípio da legalidade na execução do poder, pelo que $o$ ato de autoridade tem validade segundo sua conformação legal, o que liga toda a execução da lei à origem, que é a vontade popular. (...) enfim, é o Estado Democrático de Direito que se apresenta como organização político-estatal possibilitadora de uma legalidade legítima, que se funda nos direitos fundamentais criados soberanamente pelo próprio povo, destinatário e co-autor da ordem jurídica, é nesse Estado que a autonomia política atua contra a arbitrariedade de um poder mediante sua domesticação pelo jurídico. ${ }^{44}$
\end{abstract}

Bobbitt afirma que, o surgimento dos Estados Nação se deu a partir "dos Estados Territoriais, aqueles que, como a Inglaterra, conseguiram sobreviver acabaram transformando-se em nações-Estado no Século XIX"45. Emerge então a pergunta, o que seria Nação-estado? A resposta dada pelo autor é que seria

um Estado que mobiliza uma nação - um grupo nacional étnico-cultural para agir em benefício do Estado. Assim, pode contar com as receitas de toda a sociedade e $o$ talento humano de toda a população ${ }^{46}$

42 SILVA, José Afonso. Curso de Direito Constitucional Positivo. 32 ed. Revista e atualizada até a Emenda Constitucional no 57, de 18.12.2008. São Paulo: Malheiros Editores LTDA., 2009

43 DIAZ, Elias. Legalidad- legitimidade en el socialismo democrático. Espanha: Editorial Civitas S.A., 1978, p.120.

44 DIAZ, Elias. Legalidad- legitimidade en el socialismo democrático. Espanha: Editorial Civitas S.A., 1978, p.120.

45 BOBBITT, Philip. A Guerra e a Paz na História Moderna: o Impacto dos Grandes conflitos e da política na formação das nações. Tradução Cristiana Serra. Rio de Janeiro: Campus. 2003, p.135.

${ }^{46}$ Ibidem. 2003, p. 163. 
Portanto, têm-se o Estado como uma entidade com poder soberano para governar um povo dentro de uma área territorial delimitada. Ele é a união da sociedade em prol dela mesma, a qual designa representantes para atuarem em sua gerência. O Estado é o responsável, dentro de sua organização, pela criação e aplicação de normas. Cabe a ele, a manutenção da ordem, e o perfeito funcionamento da sociedade. Garantido assim, o bem comum.

No próximo subcapítulo analisaremos os conceitos relativos ao termo poder e sua relação com o Estado.

\subsection{DO PODER}

Neste subcapítulo analisaremos os conceitos relativos ao termo Poder.

Tendo como objeto de estudo principal os fenômenos políticos, particularmente, os relativos ao poder, a Ciência Política procura examinar criteriosamente os fatos, procurando não apenas descrever estes fenômenos, como também explicá-los. ${ }^{47}$

De acordo com Weber, poder "significa toda probabilidade de impor a própria vontade numa relação social, mesmo contra resistências, seja qual for o fundamento dessa probabilidade"48. De uma forma simples, é o direito de deliberar, agir, mandar, ou seja, exercer autoridade, soberania, influência ou força.

Segundo Bobbio,

Em seu significado mais geral, a palavra Poder designa a capacidade ou a possibilidade de agir, de produzir efeitos. Tanto pode ser referida a indivíduos e grupos humanos como a objetos ou a fenômenos naturais (como na expressão Poder calorífico, Poder de absorção). Se o entendermos em sentido especificamente social, ou seja, na sua relação com a vida do homem em sociedade, o Poder torna-se mais preciso, e seu espaço conceptual pode ir desde a capacidade geral de agir, até a capacidade do homem de

47 BOBBIO, Noberto; PASQUINO, Gianfranco; MATTEUCCI, Nicola. Dicionário de Política. Trad. Carmen C, Varriale et ai.; Coord. trad. João Ferreira; Rev. geral João Ferreira e Luis Pinto. 11. ed. 1ํㅗㅇ v. 1330p. Brasília: Editora Universidade de Brasília, 1998, p. $164-169$.

48 WEBER, Max. Economia e Sociedade: Fundamentos da sociologia compreensiva. $4^{\circ}$ ed. Vol. 1. Brasília: Editora Universidade de Brasília. 2009, p. 33. 
determinar o comportamento do homem: Poder do homem sobre o homem. O homem é não só o sujeito, mas também o objeto do Poder social. 49

Sendo um aspecto potencial nas relações sociais, o poder se caracteriza por sua condição assimétrica: o detentor do poder exerce certo controle sobre a conduta de um indivíduo que, como subalterno, sofre esta forma de agir. ${ }^{50}$

Dentro do conceito alemão, poder tem sua origem nas palavras Können e Vermögen ${ }^{51}$, porém, conforme salienta Herb, o conceito de poder tem sempre uma concorrente chamada violência ${ }^{52}$, derivada do verbo walten ${ }^{53}$ que traz o significado de ter força, reger ou dispor sobre algo. ${ }^{54}$

De acordo com o autor, poder e violência encontram-se em uma luta pela supremacia conceitual, tendo o poder algumas vantagens ao seu lado. Porém, atrás deste problema conceitual, há um grande problema filosófico. Ao se debater a respeito de poder, acaba-se por falar em violência, definido assim, concentração de poder e o monopólio da violência. Esta monopolização da força ${ }^{55}$ é, no sentido moderno da palavra, a condição necessária para que exista o Estado, independentemente de ser condição suficiente. Portanto, o detentor exclusivo do poder coativo é o Estado. ${ }^{56}$

Hobbes, ao falar a respeito do poder do homem, afirma que este "consiste nos meios de que dispõe para alcançar, no futuro, algum bem evidente, que pode ser tanto original (natural) como instrumental"57, seguindo esta definição cabe acrescentar, conforme afirma Ribeiro, que o poder

49 BOBBIO, N.; METTEUCCI, N.; PASQUINO, G. Dicionário de política. Brasília: Universidade de Brasília; São Paulo: Imprensa Oficial do Estado de São Paulo. v. 2. 2000, p. 933.

50 CONCEITO, Que. Conceito de Poder. 2016. Disponível em: <http://queconceito.com.br/poder>. Acesso em: 14 mar. 2016.

${ }^{51}$ Respectivamente, poder e ser capaz.

52 No Alemão, "Gewalt".

53 Reinar.

54 HERB, Karl Friendrich. Além do bem e do mal: o poder em Maquiavel, Hobbes, Arendt e Foucault. Revista Brasileira de Ciência Política, №10. Brasília, janeiro - abril de 2013, pp. 267-284, p. 268.

${ }^{55}$ Para Weber o monopólio do uso legítimo da força física dentro de um determinado território pertence ao Estado.

56 Ibidem.

57 HOBBES, Thomas. Leviatã ou matéria, forma e poder de um Estado eclesiástico e civil. São Paulo: Martin Claret, 2009, p. 70. 
Precede o Estado, cujo advento tem justamente a função de acabar de vez com o caráter caleidoscópico ${ }^{58}$, mutante, das relações de poder na 'condição natural da humanidade', no estado de natureza. O poder é o outro nome da desigualdade: [sendo] impossível suprimi-la. ${ }^{59}$

Tem-se então, segundo Bobbio que,

Em Hobbes, o poder por excelência é o poder político, o qual legitimado por uma específica delegação de indivíduos isolados e aterrorizados, impelidos pela necessidade a sair do estado de natureza, controla tanto o poder espiritual quanto o econômico 60

Ao comentar a obra de Hobbes, Hannah Arendt afirma que:

Na luta pelo poder (. . .), todos os homens são iguais, pois a igualdade do homem reside no fato de que cada um, por natureza, tem suficiente potencialidade para matar um outro (...). [Portanto], a igualdade coloca todos os homens na mesma insegurança; daí a necessidade do Estado ${ }^{61}$

Neste patamar da luta pelo poder, este deixa de ser um vício dos poderosos, passando a ser uma constante da natureza humana antes de toda política. Neste ponto, dominar o outro para não ser dominado, Maquiavel observa o comportamento do homem, e projeta de forma negativa uma lista do caráter humano, afirmando que "pode-se dizer dos homens, de modo geral, que são ingratos, volúveis, dissimulados; procuram se esquivar dos perigos e são gananciosos"62. Nas palavras do filósofo, aquele que almeje conquistar e manter o poder político necessita contar

58 "Pelo fato de todos possuírem um direito natural sobre tudo e, assim, tudo estar no poder de cada um, a concorrência ruinosa é inevitável. Sob tais condições, qualquer estratégia de poder, mesmo a agressão preventiva, está condenada ao fracasso" - HERB, Karl Friendrich. Além do bem e do mal: o poder em Maquiavel, Hobbes, Arendt e Foucault. Revista Brasileira de Ciência Política. Brasília, n. 10, p. 267-284. 2013, p. 273.

59 RIBEIRO, Renato Janine. A marca do leviatã - linguagem e poder em Hobbes. São Paulo: Ateliê Editorial, 2003, p. 26.

${ }^{60} \mathrm{BOBBIO}$, Noberto. Estado, governo, sociedade: por uma teoria geral da política. Tradução por Marco Aurélio Nogueira. Rio de Janeiro: Paz e Terra, p. 53-104. 2010, p.84.

61 ARENDT, Hannah. Origens do Totalitarismo. Tradução por Roberto Raposo. São Paulo: Companhia das Letras, 2009. p. 169.

62 MAQUIAVEL, Nicolau. O Príncipe: Comentado por Napoleão Bonaparte. Tradução: Pietro Nassetti. $7^{\circ}$ Ed. São Paulo: Editora Martin Claret, 2008. P. 88. 
com esta dimensão negativa, partindo do pressuposto "de que todos os homens são perversos, e que seguem sempre suas más inclinações, assim que tenham uma oportunidade"63

A solução apresentada por Hobbes para isto, seria o advento do Estado, que traria consigo a monopolização do poder nas mãos do soberano, e este, agiria em nome de seus súditos, objetivando "dominar o medo de uns diante dos outros e pacificar suas relações ${ }^{64}$, [instituindo, por sua vez], a paz entre os homens"65

A violência, o Estado e o Poder são, portanto, estritamente ligados. Poulantzas afirma que a coerção e a ameaça sobre o corpo são condições exigidas para a existência e manutenção do poder na atual sociedade. Embora não seja visível no cotidiano, a violência segundo o autor é a base para o poder e o domínio moderno.

Segundo este autor,

[...] a violência física monopolizada pelo Estado sustenta permanentemente as técnicas do poder e os mecanismos do consentimento, está inscrita na trama dos dispositivos disciplinares e ideológicos, e molda a materialidade do corpo social sobre o qual age o domínio, mesmo quando essa violência não se exerce diretamente 66

Foucault, apesar de sempre negar que o foco de seu trabalho fosse 0 poder, tem tal temática perpassando quase toda sua obra. Cabe destacar, antes de tudo, que o conceito de poder em Foucault é abstrato, não se confundido com poder disciplinar e de biopoder.

O autor assevera que

A partir do momento em que tentamos escapar do esquema economicista para analisar o poder, nos encontramos imediatamente em presença de duas hipóteses: por um lado, os mecanismos do poder seriam do tipo repressivo, ideia que chamarei por comodidade de hipótese de Reich; por outro lado, a

63 MAQUIAVEL, Nicolau . The discourses. London: Penguin.1983. I, 3.

${ }^{64}$ Para Hobbes não há meio termo, o poder absoluto seria a condição básica para o direito positivo e a paz social.

65 HERB, Karl Friendrich. Além do bem e do mal: o poder em Maquiavel, Hobbes, Arendt e Foucault. Revista Brasileira de Ciência Política. Brasília, n. 10, p. 267-284. 2013, p. 273.

66 POULANTZAS, Nicos. O Estado, o poder e o socialismo. 4ํe ed. São Paulo: Paz e Terra, 2000, p. 79. 
base das relações de poder seria o confronto belicoso das forças, ideia que chamarei, também por comodidade, de hipótese de Nietzsche. ${ }^{67}$

Mesmo com duras críticas a estas posições, Foucault acaba por reconhecer esta esfera repressiva do poder. Porém, reconhecer apenas este aspecto repressivo, seria recair em um equívoco, analisando apenas a perspectiva jurídica do poder, deixando-o de lado como prática discursiva do sujeito, indo além, visto que, todo poder acaba por gerar um contra poder.

Conforme afirma Foucault,

Quando se define os efeitos do poder pela repressão, tem-se uma concepção puramente jurídica deste mesmo poder; identifica-se o poder a uma lei que diz não. O fundamental seria a força da proibição. Ora, creio que ser esta uma noção negativa, estreita e esquelética do poder que curiosamente todo mundo aceitou. Se o poder fosse somente repressivo, se não fizesse outra coisa a não ser dizer não você acredita que seria obedecido? O que faz com que o poder se mantenha e que seja aceito é simplesmente que ele não pesa só como uma força que diz não, mas que de fato ele permeia, produz coisas, induz ao prazer, forma saber, produz discurso. Deve-se considerá-lo como uma rede produtiva que atravessa todo o corpo social muito mais do que uma instância negativa que tem por função reprimir. 68

Ainda, segundo Foucault

O exercício do poder não é simplesmente uma relação entre 'parceiros' individuais ou coletivos; é um modo de ação de uns sobre outros. O que quer dizer, certamente, que não há algo como o 'Poder' ou 'do poder' que existiria globalmente, maciçamente ou em estado difuso, concentrado ou distribuído: só há poder exercido por 'uns' sobre os 'outros'; o poder só existe em ato, mesmo que, é claro, se inscreva em um campo de possibilidade esparso que se apoia em estruturas permanentes ${ }^{69}$

${ }^{67}$ FOUCAULT, M. Microfísica do poder. Rio de Janeiro: Edições Graal, 1979, p. 179.

68 Ibidem, p. 7-8.

69 FOUCAULT, M. O Sujeito e o Poder. In: DREYFUS, H. I; RABINOW,P. Michel Foucault: Uma Trajetória Filosófica: Para Além da Estrutura e da Hermenêutica. 2ed. Rio de Janeiro: Forense Universitária, 2010, p.287. 
Foucault entende que, para que seja instituída uma relação de poder, é necessário que os indivíduos sobre os quais o poder for exercido, sejam livres, conforme salienta Revel,

\begin{abstract}
caracterizando as relações de poder como modos de ação dos outros, Foucault inclui na sua descrição a liberdade, na medida em que o poder não se exerce senão sobre sujeitos - individuais ou coletivos - 'que têm diante de si um campo de possibilidade onde diversas condutas [...] podem acontecer. Não há relação de poder onde as determinações estão saturadas'. A análise foucaultiana destrói, portanto, a ideia de um paradoxo/contradição entre o poder e a liberdade: é precisamente tornando-os indissociáveis que Foucault pode reconhecer no poder um papel não somente repressivo, mas produtivo (efeitos de verdade, de subjetividade, de lutas), e que ele pode, inversamente, enraizar os fenômenos de resistência no próprio interior do poder que eles buscam contestar, e não num improvável 'exterior'70
\end{abstract}

Com o intuito de compreender o que são as relações de poder, Foucault realiza em seus estudos uma "análise inversa", partindo sua investigação das formas de resistência ao poder. Para ele esta ação consiste em "usar essa resistência como um catalisador químico de modo a esclarecer as relações de poder, localizar sua posição, descobrir seu ponto de aplicação e os métodos empregados. "71

Tal método de análise o leva a direcionar sua concepção de poder para a forma como ele se exerce, e não para o conceito do que ele é. Desta forma, trabalha a partir do triangulo entre poder, direito e verdade. "Em sua forma, portanto, mais abstrata, o conceito foucaultiano de poder não mantém nenhum contato com os conceitos de Estado, soberania, e dominação (....."72

Foucault, portanto, propõe a construção de uma "Analítica do poder", visto que, conforme afirma, "se tentarmos construir uma teoria do poder, será necessário sempre descrevê-lo como algo que emerge num determinado lugar e num tempo

${ }^{70}$ REVEL, Judith. Michel Foucault: conceitos essenciais. Trad. Maria do Rosário Gregolin. São Carlos, SP: Claraluz, 2005, p. 67.

71 FOUCAULT, M. O Sujeito e o Poder. In: DREYFUS, H. I; RABINOW,P. Michel Foucault: Uma Trajetória Filosófica: Para Além da Estrutura e da Hermenêutica. 2ed. Rio de Janeiro: Forense Universitária. 2010, p. 276.

72 POGREBINSCHI, Thamy. Foucault, para além do poder disciplinar e do biopoder. Lua Nova, São Paulo, n. 63, p. 179-201, 2004. Available from <http://www.scielo.br/scielo.php?script=sci_arttext\&pid=S0102-64452004000300008\&lng=en\&nrm=iso >. access on 31 July 2017. http://dx.doi.org/10.1590/S0102-64452004000300008. 
dados, e daí deduzir e reconstruir sua gênese"73. Desta forma, não existe "o Poder", o que realmente existe são as relações de poder ${ }^{74}$, ou seja, "formas dispares heterogêneas, em constante transformação. O poder não é um objeto natural, uma coisa; é uma prática social e, como tal, constituída historicamente". ${ }^{75}$

$\mathrm{Na}$ "Analítica do poder"76 de Foucault uma das principais ideias que perpassam é na verdade uma espécie de deslocamento em relação à teoria política tradicional, que por sua vez, atribuía ao Estado o monopólio do poder. Tornando-se evidente nas investigações de Foucault, a existência de uma rede de micro poderes, articulados ao Estado e que atravessam toda a estrutura social. Desta forma, a análise do poder não deve partir do seu centro (o Estado) verificando como ele se exerce em níveis mais baixos da sociedade, mas sim no sentido inverso, verificando como estes micro poderes atravessam a estrutura social e se relacionam com a estrutura geral do poder que seria o Estado, realizando assim, uma análise ascendente. Conforme estabelece Foucault

Trata-se [...] de captar o poder em suas extremidades, lá onde ele se torna capilar; captar o poder nas suas formas e instituições mais regionais e locais, principalmente no ponto em que, ultrapassando as regras de direito que o organizam e delimitam, ele se prolonga, penetra em instituições, corporificase em técnicas e se mune de instrumentos de intervenção material, eventualmente violentos. ${ }^{77}$

73 FOUCAULT, Michel. POWER/KNOWLEDGE. Selected Interviews and Other Writings 1972-1977. Edited by COLIN GORDON. Translated by COLIN GORDON, LEO MARSHALL JOHN MEPHAM, KATE SOPER. Pantheon Books, New York. 1980, p.199. Tradução livre.

74 "Para Weber (1984, p.43), o conceito de poder é sociologicamente amorfo, havendo uma série de circunstâncias que colocam uma pessoa na posição de impor sua vontade devendo, portanto, 0 conceito de dominação ser mais preciso: dominação é a probabilidade de que um mandado seja obedecido." CASTRO, Magali de. Um estudo das relações de poder na escola pública de ensino fundamental à luz de Weber e Bourdieu: do poder formal, impessoal e simbólico ao poder explícito. Rev. Fac. Educ., São Paulo, v. 24, n. 1, p. 9-22, Jan. 1998 . Available from $<$ http://www.scielo.br/scielo.php?script=sci_arttext\&pid=S0102-

25551998000100002\&lng=en\&nrm=iso >. access on 04 May 2017. http://dx.doi.org/10.1590/S010225551998000100002.

75 MACHADO, Roberto. "Por uma Genealogia do Poder". In: FOUCAULT, Michel. Microfísica do Poder. Rio de Janeiro: Edições Graal, 1979, p. X.

76 "Se tentarmos construir uma teoria do poder, será necessário sempre descrevê-lo como algo que emerge num lugar e num tempo dados, e daí deduzir e reconstruir a gênese. Mas se o poder é, na realidade, um conjunto de relações abertas, mais ou menos coordenadas (e, de fato, mal coordenadas), então o único problema consiste em se munir de uma rede de análise que torne possível uma analítica das relações de poder". FOUCAULT, [1980], apud DRYEFUS; RABINOW, 2010, p. 202.

77 FOUCAULT, Michel. "Soberania e Disciplina". In: Microfísica do Poder. Rio de Janeiro: Edições Graal, 1979, p. 182. 
Esta "Analítica do poder" de Foucault apresenta um deslocamento em relação ao Estado, tendo em vista que identifica a existência de um encadeamento de relações de poder, que por sua vez, colocam-se fora dele e que de maneira alguma devem ser analisadas em termos de soberania, proibição ou de imposição de uma lei. Em contraponto, Foucault não tem como objetivo negar a importância do Estado, seu objetivo na verdade é demonstrar que as relações de poder transpõem o nível estatal e se estendem por toda a sociedade. Analisemos da seguinte maneira: não apenas 0 Estado (dentro do contexto da modernidade), é o centro de controle e de formação da sociabilidade, mas também, instituições como a escola, fábricas, quarteis, manicômios, igrejas, etc., exercem fundamental importância na formação das massas, no que tange à legitimação da racionalidade capitalista.

Sustentar que o poder se restringe ao Estado, sendo esta sua função exclusiva, seria avaliar parcialmente a ligação entre o Estado e estas instituições. Conforme Foucault:

\begin{abstract}
Situar o problema em termos de Estado significa continuar situando-o em termos de soberano e soberania, o que quer dizer, em termos de Direito. Descrever todos esses fenômenos do poder como dependentes do aparato estatal significa compreendê-los como essencialmente repressivos: o exército como poder de morte, polícia e justiça como instâncias punitivas, etc. Eu não quero dizer que o Estado não é importante; o que quero dizer é que as relações de poder, e, consequentemente, sua análise se estendem além dos limites do Estado. Em dois sentidos: em primeiro lugar, por que o Estado, com toda a onipotência do seu aparato, está longe de ser capaz de ocupar todo o campo de reais relações de poder, e principalmente porque o Estado apenas pode operar com base em outras relações de poder já existentes. $O$ Estado é a superestrutura em relação a toda uma série de redes de poder que investem o corpo, sexualidade, família, parentesco, conhecimento, tecnologia, etc. ${ }^{78}$
\end{abstract}

Observa-se, como já foi dito, que "o poder" não existe, há na realidade práticas ou relações de poder. Desta forma, o poder é algo que se exerce e, portanto, deve ser entendido antes como uma estratégia do que como um bem ou objeto.

Ora, o estudo desta microfísica supõe que o poder nela exercido não seja concebido como uma propriedade, mas como uma estratégia, que seus

78 FOUCAULT, Michel. L'impossible Prison : Recherches sur lê Systeme Pénitentiaire ao XIX Siècle. Paris: Éd.Du Seuil, 1980, p. 122. 
efeitos de dominação não sejam atribuídos a uma 'apropriação', mas a disposições, a manobras, a táticas, a técnicas, a funcionamentos; que se desvende nele antes uma rede de relações sempre tensas, sempre em atividade, que um privilégio que se pudesse deter; que se seja dado como modelo antes a batalha perpétua que o contrato que faz uma cessão ou uma conquista que se apodera de um domínio. Temos, em suma, de admitir que esse poder se exerce mais do que se possui, que não é 'privilégio' adquirido ou conservado da classe dominante, mas o efeito de conjunto de suas posições estratégicas - efeito manifestado e às vezes reconduzido pela posição dos que são dominados. ${ }^{79}$

Torna-se evidente nas investigações de Foucault uma espécie de funcionalidade do poder, ou seja, a ideia de que o poder funciona como um dispositivo ou máquina, que está disseminado por toda a estrutura social e a perpassa e não localizado em algum lugar específico.

Não existe a possibilidade das lutas contra o funcionamento do poder serem feitas de fora, do exterior, pois nada nem ninguém está livre do poder, pois, "O poder está em toda parte; não porque englobe tudo, e sim porque provém de todos os lugares". 80

Cabe lembrar que, conforme afirma o autor, "onde há poder, há resistência"81

[...] não existe [...] um lugar da grande Recusa - alma da revolta, foco de todas as rebeliões, lei pura do revolucionário. Mas sim resistências no plural, que são casos únicos: possíveis, necessários, improváveis, espontâneas, selvagens, solitárias, planejadas, arrastadas, violentas, irreconciliáveis, prontas ao compromisso, interessadas ou fadadas ao sacrifício; por definição, não podem existir a não ser no campo estratégico das relações de poder. [...]. As resistências não se reduzem a uns poucos princípios heterogêneos; mas não é por isso que sejam ilusão, ou promessa necessariamente desrespeitada. Elas são o outro termo nas relações de poder; inscrevem-se nestas relações como o interlocutor irredutível". ${ }^{82}$

Já em Hannah Arendt o poder não pode ser tido como propriedade de nenhum indivíduo, pois, pertence a um grupo e só existe na medida em que o grupo

\footnotetext{
79 FOUCAULT, Michel. Vigiar e Punir. Petrópolis: Editora Vozes, 1975, p. 29.

80 FOUCAULT, Michel. História da Sexualidade I: a Vontade de Saber. Rio de Janeiro: Edições Graal, 1976, p. 89.

81 Ibidem., p. 91

82 Ibidem, p. 91-92.
} 
se conserva unido. Para Perissinoto, tal concepção assenta-se em quatro aspectos básicos,

\begin{abstract}
Primeiro, o poder é um fenômeno do campo da ação humana; não é, portanto, uma 'estrutura', nem se iguala à posse de determinados recursos; segundo, o poder é um fenômeno do campo da 'ação coletiva'; terceiro, o poder surge na medida em que um grupo se forma e desaparece quando ele se desintegra o que reforça a tese de que o poder está ligado a um momento de fundação; por fim, 'estar no poder' significa 'estar autorizado' pelo grupo a falar em seu nome. ${ }^{83}$
\end{abstract}

O conceito de poder em Arendt, segundo Perissinotto, é marcado pela ideia de consentimento, de livre trocas de opiniões entre iguais e de apoio, sendo assim, "poder" e "violência" são expressões opostas na teoria arendtiana, onde uma domina, a outra está ausente ${ }^{84}$.

Habermas ressalta que o conceito comunicativo de poder pode levar a alguns contrassensos, quando aplicado a sociedades.

O conceito do poder comunicativamente produzido, de H. Arendt, só pode transformar-se num instrumento válido se o desvincularmos de uma teoria da ação inspirada em Aristóteles. H. Arendt faz remontar o poder político exclusivamente à práxis, a fala recíproca e à ação conjunta dos indivíduos (...). Com isso, entretanto, H. Arendt tem que pagar o preço de: a) excluir da esfera política todos os elementos estratégicos, definindo-os como violência; b) de isolar a política dos contextos econômicos e sociais em que está embutida através do sistema administrativo; c) de não poder compreender as manifestações da violência estrutural. ${ }^{85}$

Ao comentar Arendt, Habermas afirma que

Para Hannah Arendt, o fenômeno básico do poder não é, como para Max Weber, a chance de impor, no âmbito de uma relação social, a sua própria vontade contra vontades opostas, e sim, o potencial de uma vontade comum formada numa comunicação não coagida. Ela instaura um confronto entre

83 PERISSINOTTO, Renato M. Hannah Arendt, Poder e A Crítica Da "Tradição". Lua Nova, São Paulo, № 61: P. 115-138. 2004, p. 118.

84 Ibidem, p. 118.

85 HABERMAS, Jürgen. Sociologia. São Paulo: Ática, 1980. (Grandes Cientistas sociais; 15). P. 110 111. 
poder de uma comunicação voltada ao entendimento e a instrumentalização de uma vontade estranha em proveito próprio [...]. ${ }^{86}$

Este conceito desenvolvido por Arendt, não reconhece qualquer forma que instrumentalize o poder, na concepção da autora o poder se configura como "um potencial para a imposição de interesses próprios ou a realização de fins coletivos, nem um poder administrativo capaz de tomar decisões obrigatórias coletivamente" 87 visto ser incompatível com o poder constituído, ao invés disto, ele é uma força autorizadora a qual se manifesta na criação do direito legítimo e na fundação de instituições.

Desta forma, o poder para Hannah Arendt não pode ser considerado como violência, visto que, mesmo constantemente nascendo juntos, são fenômenos diferentes. A autora define o poder como "fortaleza" na qual observa-se a presença da força que, por sua vez, nem sempre é baseada na violência.

Conforme afirma a autora:

Fenomenologicamente está próxima de fortaleza, uma vez que os implementos da violência, como qualquer outra ferramenta, são projetados e usados para multiplicar a fortaleza natural até que no último estágio de seu desenvolvimento possam substituí-la. ${ }^{88}$

Ao trazer este conceito, Arendt suprime o uso instrumental da violência o que se relaciona ao poder legítimo, que, segundo ela, "obtém sua legitimidade mais do ato inicial de unir-se do que de outras ações que se possam seguir". ${ }^{89}$

Habermas afirma que

Max Weber definiu o poder como a possibilidade de impor a própria vontade ao comportamento alheio. Hannah Arendt, ao contrário, concebe o poder como a faculdade de alcançar um acordo quanto à ação comum, no contexto da comunicação livre de violência. Ambos veem no poder um potencial que

${ }^{86}$ HABERMAS, Jürgen. Direito e Democracia: entre facticidade e validade. Volume I. 2 Edição. Rio de Janeiro: Tempo Brasileiro. 2003, p. 187.

87 Ibidem. p. 188.

${ }^{88}$ ARENDT, Hannah. Crises da República. São Paulo: Perspectiva. 2004, p. 124.

89 Ibidem, p.129. 
se atualiza em ações, mas cada um se baseia num modelo de ação distinto. ${ }^{90}$ (Traduzido pelo autor)

Em busca de uma definição o autor esclarece que,

Devemos distinguir a dominação, ou seja, o exercício do poder político, tanto da aquisição e preservação deste poder, como da sua gestação. Nesse último caso, e somente nele, o conceito de práxis pode auxiliar-nos. Nenhum detentor de posições de dominação pode exercer o poder, e ninguém poderá disputá-lo, se tais proposições não estiverem ancoradas nas leis e instituições políticas, cuja sobrevivência repousa, em última instância, sobre as conviçcões comuns, sobre a opinião "em torno da qual muitos se puseram publicamente de acordo ${ }^{91}$

Com base neste contexto, Habermas constrói seu conceito de poder, utilizando-se da relação entre o pensamento liberal e o republicano, além dos conceitos de Arendt e Weber. Com o conceito de poder, o autor busca reconstruir a relação interna entre direito e política.

Ao estabelecer por fim o seu conceito, Habermas afirma o seu duplo aspecto. Ao mesmo tempo que ele é gerado por uma força proveniente da união entre indivíduos que buscam o entendimento, a sua manutenção e exercício dependem de uma noção teleológica capaz de colocar objetivos que solucionem os problemas levantados no momento da comunicação. A política, como exercício do poder, relaciona-se com o direito de formas diferenciadas na modernidade e em relação ao modelo de sociedade que a precede.

No próximo subcapítulo, trataremos a respeito do Biopoder, suas origens e definições.

90 HABERMAS, Jürgen. La Inclusión del Otro - estudios de teoría política. Buenos Aires: Editora Paidós. 1999, p. 100.

91 HABERMAS, Jürgen. O Conceito de Poder de Hannah Arendt. In FREITAG, Bárbara; ROUANET,Sérgio Paulo (orgs). Habermas - Sociologia. São Paulo: Ática. 1993, p. 112. 


\subsection{DO BIOPODER}

O conceito de biopoder foi cunhado originalmente por Michel Foucault, sendo apresentado oficialmente, no primeiro volume do livro História da Sexualidade. Tais questões e problematizações, acerca das noções de Biopolítica, população e Biopoder, são encontradas na obra do autor, ainda que de forma germinal, a partir de meados dos anos 1970.

Este novo conceito (Biopoder), veio a se juntar às reflexões acerca das práticas disciplinares. Tais disciplinas voltavam-se para o indivíduo e para o seu corpo, visando o adestramento através das diversas instituições modernas que esse indivíduo cruzaria por sua vida.

Passando por estas instituições os corpos docilizavam-se, tornando-se aptos à produção industrial. Conforme Foucault estas disciplinas centravam-se,

No corpo como máquina: no seu adestramento, na ampliação de suas aptidões, na extorsão de suas forças, no crescimento paralelo de sua utilidade e docilidade, na sua integração em sistemas de controle eficazes e econômicos ${ }^{92}$

Estando estritamente ligada ao momento histórico em que está inserida, esta técnica de poder fora a responsável pela consolidação do processo de industrialização e da otimização da força de trabalho. Em consequência do aumento da produção e do lucro, tornou-se necessário controlar as massas populacionais, tornando os corpos dóceis e disciplinados, para assim serem eficientes ao modelo de produção que se consolidava.

A este respeito, utilizando-se das palavras de Michael Foucault, pode-se afirmar que o biopoder

Foi elemento indispensável ao desenvolvimento do capitalismo, que só pôde ser garantido à custa da inserção controlada dos corpos no aparelho de produção e por meio de um ajustamento dos fenômenos de população aos

92 FOUCAULT, Michel. História da Sexualidade I: a vontade de saber. Rio de Janeiro: Edições Graal. 1988, p. 151. 
processos econômicos. Mas o capitalismo exigiu mais do que isso; foi-lhe necessário o crescimento tanto de seu esforço quanto de sua utilizabilidade e sua docilidade; foram-lhe necessários métodos de poder capazes de majorar as forças, as aptidões, a vida em geral, sem por isto torna-las mais difíceis de sujeitar (...). ${ }^{93}$

Desta forma, vê-se necessário a utilização de uma técnica de poder que não fosse apenas individualizante, mas também massificante. Desta forma, apresenta-se o que o autor denominou de biopolítica, que pode ser entendida como a inserção da vida natural do homem nos mecanismos e nos cálculos do poder.

O Biopoder é a gestão da vida como um todo, é a aplicação de técnicas de poder sobre o biológico, tornando-se assim, central nos debates políticos. Tendo como objetivos do Biopoder, modificar, transformar, evoluir e produzir conhecimento, saber acerca dele, para melhor manejá-lo. Assim, como a disciplina fora necessária para a docilização do corpo produtivo fabril, o Biopoder fora de extrema importância para o desenvolvimento do capitalismo. "O investimento sobre o corpo vivo, sua valorização e a gestão distributiva de suas forças foram indispensáveis naquele momento". ${ }^{94}$

Em sociedades de autoridade, o direito sobre a vida e a morte de seus súditos pertence ao soberano. Segundo Foucault "o direito que é formulado como 'de vida e morte' é, de fato, o direito de causar a morte e deixar viver"95, assim, um poder que consiste em fazer viver e deixar morrer, pode ser entendido como

\begin{abstract}
Um conjunto de processos como a proporção dos nascimentos e dos óbitos, a taxa de reprodução, a fecundidade de uma população, etc. são esses processos de natalidade, de mortalidade, de longevidade que, justamente na segunda metade do século XVIII, juntamente com uma porção de problemas econômicos e políticos, constituíram, acho eu, os primeiros objetos de saber e os primeiros alvos de controle dessa biopolítica. (...) O poder, no século XIX, tomou posse da vida, dizer pelo menos que o poder, no século XIX, incumbiu-se da vida, é dizer que ele conseguiu cobrir toda a superfície que se estende do orgânico ao biológico, do corpo à população, mediante o jogo duplo das tecnologias de disciplina, de uma parte, e das tecnologias de regulamentação, de outra. ${ }^{96}$
\end{abstract}

93 FOUCAULT, Michel. História da Sexualidade I: a vontade de saber. Rio de Janeiro: Edições Graal. 1988, p.132.

94 Ibidem, p. 154.

95 Ibidem, p. 148.

${ }^{96}$ FOUCAULT, Michel. Em defesa da sociedade. Curso no Collège de France (1975-1976). São Paulo:

Ed. Martins Fontes. 2000, p. 286. 
A esfera de atuação do Biopoder é a cidade, a população, ou seja, o coletivo como diversidade política, biológica e científica, transmutando a disciplina em mecanismos reguladores. Conforme ressalta Nunes

\begin{abstract}
A população aparece como um problema econômico e político. Os Governos percebem que não têm de lidar simplesmente com sujeitos, mas com uma população com seus fenômenos específicos e suas variáveis próprias: natalidade, mortalidade, esperança de vida, fecundidade, estado de saúde, incidência de doenças, formas de alimentação, hábitat e formas de sociabilidade. ${ }^{97}$
\end{abstract}

Entretanto, o poder sobre a vida, nas sociedades disciplinares, não mais se volta aos momentos em que ela pode se extinguir. A contraponto, o Biopoder trata de organizar e gerir a vida em toda a sua extensão, vigiando para que o indivíduo possa ser incluído e controlado. Não se trata mais de uma lei que vise a vida e a morte, tratase de "distribuir os vivos em um domínio de valor e utilidade"98.

Outros autores a teorizarem a respeito do Biopoder foram Antonio Negri e Michael Hardt, que têm sua perspectiva de análise dentro das mesmas linhas estabelecidas por Foucault, porém, com algumas diferenciações. Na compreensão dos autores, biopoder é

\begin{abstract}
A forma de poder que regula a vida social por dentro, acompanhando-a, interpretando-a, absorvendo-a e a rearticulando. O poder só pode adquirir comando efetivo sobre a vida total da população quando se torna função integral, vital, que todos os indivíduos abraçam e reativam por sua própria vontade. Como disse Foucault, ' a vida agora se tornou objeto de poder'. A função mais elevada desse poder é envolver a vida totalmente, e sua tarefa primordial é administrá-la. O Biopoder, portanto, se refere a uma situação na qual o que está diretamente em jogo no poder é a produção e a reprodução da própria vida.(Grifo nosso) ${ }^{99}$
\end{abstract}

Habermas, ao cunhar uma sintética definição do biopoder, afirma que

\footnotetext{
97 NUNES, Silvia Alexim. O Corpo do Diabo entre a cruz e a caldeirinha: um estudo sobre a mulher, o masoquismo e a feminilidade. Rio de Janeiro: Civilização Brasileiro. 2000, p.20.

${ }^{98}$ FOUCAULT, Michel. História da Sexualidade I: a vontade do saber. 7. Ed. Rio de Janeiro: Edições Graal. 1998, p. 157.

${ }_{99}$ NEGRI, Antonio; HARDT, Michael. Império. Rio de Janeiro/São Paulo: Ed. Record. 2001, p. 43.
} 
Para a formação moderna do poder, que deve o nome de biopoder ao fato de penetrar profundamente no corpo reificado e de se apoderar de todo o organismo pelas vias sutis da objetivação científica e de uma subjetividade gerada pelas tecnologias de verdade, biopoder é o nome dado àquela forma de socialização que elimina toda espontaneidade natural e transforma a vida das criaturas como totalidade num substrato da sistematização do poder ${ }^{100}$

Outro autor que é necessário ser lembrado é Giorgio Agamben, o qual aborda a questão do poder dentro do paradigma do estado de exceção. Ele sugere que o nascimento do biopoder na modernidade marca o ponto no qual a vida biológica dos sujeitos entra na política e pertence inteiramente ao Estado. Houve uma politização da vida e, desta forma, a política tornou-se biopolítica, visto que, no paradigma dos estados totalitários, o corpo e o seu respectivo controle passaram a ser a principal referência para a tomada de decisões políticas. A vida e a morte deixam de ser realidades objetivas e passam a ser conceitos políticos, os quais, adquirem seus significados através de uma decisão. ${ }^{101}$

De forma geral, torna-se então possível definir o biopoder como a capacidade do Estado em gerenciar a vida humana, sobre todos os aspectos possíveis, mas principalmente, no que diz respeito ao uso do corpo, da vida e da morte.

No próximo subcapítulo trataremos a respeito da dominação do corpo feminino, objeto de variados debates bioéticos.

\subsection{DA DOMINAÇÃO DO CORPO FEMININO}

Desde o alvorecer da humanidade o corpo foi impreterivelmente o primeiro território de edificação das relações, e desta forma, de dominação e controle dos indivíduos.

100 HABERMAS, Jürgen. Discurso Filosófico da Modernidade. Lisboa: Editora Dom Quixote. 1990, p.267.

${ }^{101}$ AGAMBEN, Giorgio. Homo Sacer: o poder soberano e á vida nua I. Belo Horizonte: Editora UFMG. 2002, p. 171. 
O conceito de biopoder apresentado por Foucault, trouxe uma nova forma de dominação e controle do território-corpo, ou seja, agenciamento e controle da vida, expondo uma nova perspectiva a respeito das relações de poder entre o estado e os indivíduos.

O fato de a racionalidade biopolítica incidir sobre o elemento fundamental, vida, acaba por trazer o significado de que o Estado, utilizando de suas ações de governo sobre os indivíduos e sobre a população, apoiam-se neste elemento, desenvolvendo uma serie de intervenções políticas que acabam por configurar a biopolítica estabelecida por Foucault. Conforme afirma o autor,

\begin{abstract}
Pela primeira vez na história, sem dúvida, o biológico se refletiu no político; o fato de viver não é mais esse subsolo inacessível que não emerge senão de tempos em tempos, no acaso da morte e da fatalidade; ele passa para uma outra parte no campo de controle do saber e da intervenção do poder. Este não se encarregará apenas de assuntos de direito, a respeito dos quais a derradeira contenda é a morte, mas dos seres vivos, e a captura que ele poderá exercer sobre eles deverá se colocar ao nível da vida, considerada nela mesma. É a tomada da vida a seu encargo mais do que a ameaça da morte, que dá ao poder seu acesso ao corpo. [...] Entretanto, o que se poderia denominar o 'limiar da modernidade biológica' de uma sociedade situa-se no momento em que uma espécie ingressa como aposta no jogo das próprias estratégias políticas. Durante milênios, o homem permaneceu o que era para Aristóteles: um animal vivente e, além disso, capaz de uma existência política; o homem moderno é uma animal em cuja política está em questão sua vida de ser vivente. ${ }^{102}$
\end{abstract}

Com o desenvolvimento da biopolítica, acabam por se juntarem saberes como a demografia, a estatística e as políticas de controle da população aos saberes e tecnologias de poder que por sua vez caracterizavam o poder disciplinar. Completase, portanto, o poder sobre a vida a partir do momento em que os métodos disciplinares que atuam sobre o indivíduo-corpo se juntam ao poder regulamentador que incide sobre os processos globais gerados ao nível da população.

Com o surgimento das grandes cidades, os centros de poder administrativo ficaram incumbidos de construir políticas de intervenção com o objetivo de controlar e regular os efeitos oriundos da vida em sociedade. Tais efeitos dizem referência à

102 FOUCAULT, Michel. História da Sexualidade I: a vontade do saber. 7. Ed. Rio de Janeiro: Edições Graal. 1998, p. 134. 
higienização das cidades via políticas sanitárias, criação e regulamentação de cemitérios, combate a epidemias, etc.

Tal demanda causada pela intensificação do convívio em espaços urbanos, obriga o Estado a criar políticas de regulamentação, inventando e colocando em funcionamento técnicas de poder.

A exemplo disto, pode-se citar, a intervenção do Estado nos domínios da sexualidade dos indivíduos a fim de controlar a taxa de natalidade. Desta forma, com a vida nas mãos do poder estatal, a saúde dos indivíduos tornou-se objeto de controle do estado, este com o objetivo de evitar doenças em massa.

Conforme salienta Foucault, Nessa biopolítica, não se trata simplesmente do problema da fecundidade.
Trata-se também do problema da morbidade, não mais simplesmente, como
justamente fora o caso até então, no nível daquelas famosas epidemias cujo
perigo havia atormentado tanto os poderes políticos desde a Idade Média
(aquelas famosas epidemias que eram drama temporários da morte
multiplicada, da morte tornada iminente para todos). Não é de epidemias que
se trata naquele momento, mas de algo diferente, no final do século XVIII:
grosso modo, aquilo que se poderia chamar de endemias, ou seja, a forma,
a natureza, a extensão, a duração, a intensidade das doenças reinantes
numa população. Doenças mais ou menos difíceis de extirpar, e que não são
encaradas como as epidemias, a título de causas de morte mais frequente,
mas como fatores permanentes - e é assim que as tratam - de subtração das
forças, diminuição do tempo de trabalho, baixa de energias, custos
econômicos, tanto por causa da produção não realizada quanto dos
tratamentos que podem custar. Em suma, a doença como fenômeno e
população: não mais como a morte que se abate brutalmente sobre a vida -
é a epidemia - mas como a morte permanente, que se introduz
sorrateiramente na vida, a corrói perpetuamente, a diminui e a enfraquece ${ }^{103}$

O poder sobre a sexualidade pode ser considerado como um dos domínios em que o poder disciplinar e a biopolítica se entrelaçam objetivando uma estratégia de controle ao mesmo tempo individualizante e massificadora.

Foucault afirma que,

Se a sexualidade foi importante, foi por uma porção de razões, mas em especial houve estas: de um lado, a sexualidade, enquanto comportamento exatamente corporal, depende de um controle disciplinar, individualizante, em

103 FOUCAULT, Michel. Em defesa da sociedade. Curso no Collège de France (1975-1976). São Paulo: Ed. Martins Fontes. 2000, p. 290 - 291. 
forma de vigilância permanente; e depois, por seus efeitos procriadores, em processos biológicos amplos que concernem não mais ao corpo do indivíduo, mas a esse elemento, a essa unidade múltipla constituída pela população. A sexualidade está exatamente na encruzilhada do corpo e da população. Portanto, ela depende da disciplina, mas depende de regulamentação. ${ }^{104}$

No que tange, especificamente à dominação, controle e domesticação do corpo e da sexualidade da mulher, é perceptível que, no curso da história das sociedades, tal fato sempre foi significativo e constante, principalmente com o surgimento da Era Moderna.

Em especial, no Brasil, desde a sua colonização, há uma hierarquização extrema entre os sexos, com mecanismos eficazes de controle do corpo e da sexualidade da mulher. Estando a condição feminina no Brasil colônia associada aos interesses familiares, políticos, econômicos, religiosos e sociais da época, visando assim, preencher a preocupação do Estado português com o vazio demográfico da colônia. ${ }^{105}$

O aborto sempre teve repugnação por parte da igreja e do Estado de forma muito intensa. Apesar de não ser tipificado como crime, o aborto no Brasil colonial, salienta Del Priore

As teses de moralistas e canonistas tornavam-se perceptíveis às camadas populares e aos fiéis, sobretudo pelos manuais de confessores. Eles traziam recomendações precisas para condenar sistematicamente o aborto, controlar suas formas de puni-lo com penitências que variavam de três a cinco anos de duração. (...) A igreja matava, assim, dois coelhos com uma só cajadada, além, é claro, de afirmar-se como juíza dos comportamentos femininos e de vincar o seu poder de instituição moralizadora sobre as novas terras coloniais. O aborto passava a ser visto, sobretudo depois longa campanha da igreja, como uma atitude que 'emporcalhava' a imagem ideal que se desejava para a mulher. ${ }^{106}$

104 FOUCAULT, Michel. Em defesa da sociedade. Curso no Collège de France (1975-1976). São Paulo: Ed. Martins Fontes. 2000, p. 289-300.

105 DEL PRIORE, Mary. Ao sul do corpo: condição feminina, maternidades e mentalidades no Brasil Colônia. Rio de Janeiro: José Olympio. Brasília, DF: Edunb. 1993, p. 123.

106 Ibidem. 1993, p. 297. 
A despeito de todas as condenações morais por parte do Estado e da igreja a respeito do aborto, é imprescindível notar que ${ }^{107}$, tal prática não era tipificada como crime até 1830. 108

Não obstante, o atual Código Penal brasileiro ${ }^{109}$ exclui a ilicitude do aborto em caso de violência sexual e de risco de vida para a gestante, porém, o mesmo diploma legal é profundamente restrito à interrupção da gravidez nas demais circunstâncias.

Tal restrição, torna-se extremamente visível quando comparada a outros países do mundo com regime democrático já em estágio mais avançado e em alguns países da América Latina.

O aborto e a sua criminalização tem sido objeto de intensos debates e embates dentro do espaço público político, sendo na sociedade brasileira objeto de muita polêmica e discussão. ${ }^{110}$

Estes debates acerca da prática do aborto e sua criminalização, estão ligados à movimentação de mulheres enquanto movimento organizado, buscando igualdade de direitos, e pelo direito de controle do seu corpo e da sua sexualidade.

\title{
1.5 DIREITOS SEXUAIS E REPRODUTIVOS
}

\begin{abstract}
Mães, filhas, irmãs, mulheres representantes da nação reivindicam constituirse em uma assembléia nacional. Considerando que a ignorância, o menosprezo e a ofensa aos direitos da mulher são as únicas causas das desgraças públicas e da corrupção no governo, resolvem expor em uma declaração solene, os direitos naturais, inalienáveis e sagrados da mulher. Assim, que esta declaração possa lembrar sempre, a todos os membros do corpo social seus direitos e seus deveres; que, para gozar de confiança, ao ser comparado com o fim de toda e qualquer instituição política, os atos de
\end{abstract}

107 TINOCO, Antonio Luiz. Código criminal do Império do Brasil anotado. Ed. Fac-similar, Brasília: Senado Federal/Conselho Editorial. 2003. "Art. 199 - Occasionar aborto por qualquer meio empregado interior ou exteriormente com consentimento da mulher pejada. Penas - de prisão com trabalho por um a cinco anos. Se este crime fôr cometido sem o consentimento da mulher peja. Penas - dobradas. Art. 200 - Fornecer com o conhecimento de causa drogas ou quaesquer meios para produzir o aborto, ainda que este não se verifique. Penas - de prisão com trabalhos por dous ou seus annos. Se este crime fôr cometido por medico, boticário, cirurgião ou praticante de taes artes. Penas - dobradas."

${ }^{108} \mathrm{~A}$ questão será melhor detalhada no subcapítulo 2.1., sendo realizada uma melhor cronologia desta discussão.

109 Decreto Lei № 2.848, de 7 de Dezembro de 1940.

110 Atualmente no congresso brasileiro encontram-se ativos mais de vinte e cinco projetos de leis relativos ao aborto. MACHADO, Gustavo Silveira. Projetos de lei sobre aborto em tramitação na Câmara dos Deputados. 2007 
poder de homens e de mulheres devem ser inteiramente respeitados; e, que, para serem fundamentadas, doravante, em princípios simples e incontestáveis, as reivindicações das cidadãs devem sempre respeitar a constituição, os bons costumes e o bem estar geral.

Em conseqüência, o sexo que é superior em beleza, como em coragem, em meio aos sofrimentos maternais, reconhece e declara, em presença, e sob os auspícios do Ser Supremo, os seguintes direitos da mulher e da cidadã. ${ }^{111}$

O texto, acima citado, encontra-se no preambulo da Declaração dos Direitos da Mulher e da Cidadã de 1791. De autoria de Olympe Gouges e inspirado pelos ideais revolucionários de liberdade, igualdade e solidariedade, levou à guilhotina em 1793 a autora. ${ }^{112}$

A reivindicação dos direitos das mulheres, como forma de resposta aos séculos de opressão e discriminação, formulou as bases para a construção dos movimentos feministas e, em decorrer disto, para a conquista de inúmeros direitos.

Conforme esclarece Bobbio, a ideia de atribuir aos direitos humanos um fundamento absoluto é infundada, sendo que, não existem direitos fundamentais por natureza113. O autor afirma que "o que parece fundamental numa época histórica e numa determinada civilização não é fundamental em outras épocas e em outras culturas"114. Sendo assim, o direito e a ciência do Direito, têm que estar em constante evolução, acompanhando o desenvolvimento da sociedade.

Apesar da apresentação da Declaração dos Direitos da Mulher e da Cidadã em 1791, apenas em 1948 a Assembleia Geral da Organizações das Nações Unidas (O.N.U.) formulou a Declaração Universal dos Direitos Humanos (D.U.D.H.). Evoluindo desde então, a construção e o reconhecimento dos direitos humanos vêm se expandindo a esferas de importância vital para a preservação da dignidade humana. No decorrer deste processo, denominado de especificação dos sujeitos de direitos, levou-se em conta as especificidades de indivíduos e grupos, distanciando-

111 GOUGES, Olympe de. Declaração dos direitos da mulher e da cidadã - 1791. Disponível em: http://www.direitoshumanos.usp.br/index.php/Documentos-anteriores-\%C3\%A0-cria\%C3\%A7\%C3\%A 3o-da-Sociedade-das-Na\%C3\%A7\%C3\%B5es-at\%C3\%A9-1919/declaracao-dos-direitos-da-mulher-e -da-cidada-1791.html> Acessado em 24 de outubro de 2016.

112 ASSMANN, Selvino José. Declaração dos direitos da mulher e da cidadã. Revista Internacional Interdisciplinar INTERthesis, Florianópolis, v. 4, n. 1, p. 1-5, jan. 2007. ISSN 1807-1384. Disponível em: $<$ https://periodicos.ufsc.br/index.php/interthesis/article/view/911/10852>. Acesso em: 24 out. 2016. doi:http://dx.doi.org/10.5007/911.

113 BOBBIO, Norberto. A Era dos Direitos. Rio de Janeiro: Campus, 1992.

114 Ibidem. P. 19. 
se da figura abstrata do homem, com o objetivo de atender as diferenças existentes entre sexos, raças, gerações, opção sexual, entre outros. ${ }^{115}$

Foi com base neste contexto que surgiram, posteriormente, os direitos das mulheres e, em consequência destes, os direitos sexuais e reprodutivos (D.S.R), consolidados na última década do século $X X$.

Conforme afirma Mattar "O termo 'direitos reprodutivos' tornou-se público no I Encontro Internacional de Saúde da Mulher realizado em Amsterdã, Holanda, em 1984"(Grifo Nosso) ${ }^{116}$ sendo um consenso global que esta denominação "traduzia um conceito mais completo e adequado do que 'saúde da mulher' para a ampla pauta de autodeterminação reprodutiva das mulheres"117.

O desenvolvimento do conteúdo dos direitos reprodutivos foi marcado pela desconstrução da maternidade como um dever, por meio, principalmente, da luta pelo direito ao aborto e anticoncepção em países desenvolvidos. ${ }^{118}$

Sendo consagrado na Conferência Internacional de População e Desenvolvimento (C.I.P.D.), realizada no Cairo, Egito, em 1994, os direitos reprodutivos

[...] abrangem certos direitos humanos já reconhecidos em leis nacionais, em documentos internacionais sobre direitos humanos e em outros documentos consensuais. Esses direitos se ancoram no reconhecimento do direito básico de todo casal e de todo indivíduo de decidir livre e responsavelmente sobre o número, o espaçamento e a oportunidade de ter filhos e de ter informações e os meios de assim o fazer, e o direito de gozar do mais elevado padrão de saúde sexual e reprodutiva. Inclui também seu direito de tomar decisões sobre a reprodução livre de discriminação, coerção ou violência, conforme expresso em documentos sobre direitos humanos. ${ }^{119}$

115 PITANGUY, J. O Movimento Nacional e Internacional de Saúde e Direitos Reprodutivos. In: GIFFIN, Karen e COSTA, Sarah H. (orgs.). Questões da Saúde Reprodutiva. Rio de Janeiro: FIOCRUZ, p. 19-38, 1999 , p. 37.

116 MATTAR, Laura Davis. Reconhecimento jurídico dos direitos sexuais: uma análise comparativa com os direitos reprodutivos. Sur, Rev. int. direitos human., São Paulo , v. 5, n. 8, p. 60-83, June 2008. p. 63. Available from <http://www.scielo.br/scielo.php?script=sci_arttext\&pid=S180664452008000100004\&lng=en\&nrm=iso >. access on 24 Oct. 2016. http://dx.doi.org/10.1590/S180664452008000100004 .

117 Ibidem.

${ }^{118}$ CORREAA, S. Saúde Reprodutiva, Gênero e Sexualidade: legitimação e novas interrogações. In: GIFFIN, K. e COSTA, S.H. (orgs.). Questões da Saúde Reprodutiva. Rio de Janeiro: FIOCRUZ, p. 39-50, 1999, p. 41.

119PATRIOTA, Tania. Relatório da Conferência Internacional sobre População e Desenvolvimento - Plataforma de Caíro, 1994. Texto Integral do Relatório da Conferência Internacional sobre População e Desenvolvimento. Cairo, Egito. 5 a 13 de setembro de 1994.p. 62. 
Tendo seu debate iniciado em meados da década de 1980 com a epidemia do Human Immunodeficiency Virus (H.I.V.) $)^{120}$, os direitos sexuais foram debatidos, principalmente, dentro do movimento gay e lésbico, que se juntaria posteriormente ao movimento feminista. ${ }^{121}$

Os direitos sexuais são, em resumo,

Direito de viver e expressar livremente a sexualidade sem violência, discriminação e imposições e com respeito pleno pelo corpo do(a) parceiro(a).

Direito de escolher o(a) parceiro(a) sexual.

Direito de viver plenamente a sexualidade sem medo, vergonha, culpa e falsas crenças.

$[\ldots]$

Direito de expressar livremente sua orientação sexual: heterossexualidade, homossexualidade, bissexualidade, entre outras.

$[\ldots]^{122}$

O surgimento dos direitos sexuais e reprodutivos é, em síntese, fruto da contribuição dos movimentos feministas mundiais, os quais iniciaram suas discussões acerca dos padrões socioculturais vigentes, relacionados à vida e à reprodução humana.

Cabe ressaltar o marco estabelecido pela Declaração de Viena, que reconhece a violação sexual como uma afronta aos direitos humanos. ${ }^{123}$ Este reconhecimento vem se estabilizando. O Convention on the Elimination of all Forms

120 H.I.V é sigla referente a imunodeficiência humana que pode levar a síndrome da imunodeficiência adquirida (AIDS). Para maiores informações a respeito acesso o portal da Unaids em: http://unaids.org.br/2017/03/voce-sabe-o-que-e-hiv-e-o-que-e-aids/

${ }_{121}$ CORRÊA, S. e ÁVILA, M.B. Direitos Sexuais e Reprodutivos - Pauta Global e Percursos Brasileiros. In: BERQUÓ, E. (org.). Sexo \& Vida: Panorama da Saúde Reprodutiva no Brasil. Campinas, SP: Editora da UNICAMP, p. 17-78, 2003, p. 21.

122 BRASIL. Direitos sexuais, direitos reprodutivos e métodos anticoncepcionais. Ministério da Saúde. Secretaria de Atenção à Saúde. Departamento de Ações Programáticas Estratégicas. Brasília: Ministério da Saúde. 2009, p. 4.

123 LIMA, Sarah Dayanna Lacerda Martins. Os Direitos Reprodutivos das Mulheres e a Comissão Interamericana de Direitos Humanos: Uma Análise dos Casos Admitidos entre 2000 e 2013. Revista do Instituto Brasileiro de Direitos Humanos, v. 14, n. 14, 2014. 
od Discrimination Against Women ${ }^{124}$ (CEDAW) ${ }^{125}$ condenou o Peru ${ }^{126}$, considerando a negação ao pedido de procedimento de aborto de uma jovem que havia sido estuprada, uma violação dos direitos humanos. ${ }^{127}$

Conforme afirma Cabrera et al,

"la falta de cumplimiento de dichas obligaciones entranã uma violación de compromissos vinculantes, contenidos tanto en instrumentos nacionales como también en tratados internacionales legalmente assumidos y regidos pose I principio pacta sunt servanda"128

Os autores ainda complementam, esclarecendo que, os direitos sexuais e reprodutivos são direitos humanos cuja violação atenta contra o igual respeito e

124 Segundo o C.E.D.A.W "O aborto inseguro é uma das principais causas de mortalidade e morbidade materna. Assim, os Estados partes devem legalizar o aborto, pelo menos nos casos de estupro, incesto, ameaça à vida e/ou à saúde da mãe, ou comprometimento fetal grave, bem como proporcionar às mulheres acesso a atendimento pós-aborto de qualidade, em casos de complicações resultantes de abortos inseguros. Os Estados partes devem também revogar as medidas punitivas para as mulheres que se submetem a um aborto", Comitê da CEDAW, "Declaração do Comitê para a Eliminação da Discriminação contra as Mulheres sobre saúde e direitos sexuais e reprodutivos: Além da Revisão da CIPD para 2014". 57ำ Sessão (10 a 28 de fevereiro de 2014), http://www.ohchr.org/Documents/HRBodies/CEDAW/Statements/SRHR26Feb2014.pdf (acessado em 05 de maio de 2017).

125 Em relação ao Brasil o comitê do C.E.D.A.W comentou em 2012 que "Lamenta que as mulheres que se submetem a abortos ilegais continuem sujeitas a sanções penais no Estado-parte e que a proteção das mulheres em matéria de saúde e direitos sexuais e reprodutivos esteja ameaçado por uma série de projetos de lei em debate no Congresso Nacional, como o projeto de lei $n^{\circ} 478 / 2008$ (Estatuto do Nascituro)". Comitê da CEDAW, "Observações Finais do Comitê para a Eliminação da Discriminação contra a Mulher: Brasil”, ONU Doc. CEDAW/C/BRA/CO/7, 23 de março de 2012, para. 28.

${ }^{126}$ Em 2011 o C.E.D.A.W declarou em relação ao caso Alyne da Silva Pimentel Teixeira, que o Estado brasileiro era responsável pelas violações dos artigo 2(c) (acesso à justiça); artigo 2(e) (obrigação do Estado de regulamentar atividades de provedores de saúde particulares), em conexão com o artigo 1 (discriminação contra a mulher), lidos em conjunto com a Recomendação Geral no 24 (sobre mulheres e saúde) e no 28 (relativa ao artigo 2 da Convenção); e artigo 12 (acesso à saúde), reforçando, assim, a necessidade do Brasil em aprimorar os Direitos Sexuais e Reprodutivos. Para melhores informações a respeito do caso Alyne v. Brasil acessar em: https://www.reproductiverights.org/sites/crr.civicactions.net/files/documents/LAC_Alyne_Factsheet_Po rtuguese_10\%2024\%2014_FINAL_0.pdf

127 WiCHTERICH, Christa. Direitos Sexuais e Reprodutivos. Rio de Janeiro. Heinrich Boll Foundation. 2015, p. 14.

128 "A falta de cumprimento dessas obrigações implica violação Compromissos assumidos, contidas nos instrumentos nacionais, bem como nos tratados internacionais e regido legalmente assumidos $e$ regidos pelo princípio pacta sunt servanda" CABRERA, Oscar. PUCCIO, Luis Lamas. MICHEL, Agustina Ramón. CASAS, Lídia. CAVALLO, Mercedes. AHUMADA, Claudia. CASAS, Ximena. Los Derechos Reproductivos: Um debate necessário. I Congresso Lationoamericano Jurídico sobre Derechos Reproductivos. Arequipa, Perú. 5,6 y 7 de noviembre de 2009. 1ํed. Lima, Perú. Erre\&Erre artes Gráficas. 2011, p. 18. 
consideração que merecem todos os seres humanos como indivíduos, capazes de estabelecer seus próprios acordos com seus interesses e projetos pessoais. ${ }^{129}$

Para finalizar esta pequena conceituação, vale ressaltar que, conforme Cabrera et al, "Em la medida em que solo las mujeres pueden abortar, la penalización del aborto se convierte en una disposición dirigida a sus cuérpos y decisiones, a lo que se añade las consecuencias que tiene la ilegalidad em sus vidas y salud"130.

No próximo capítulo, procura-se evidenciar as relações que determinam a atuação dos Congressos brasileiro e Uruguaio no que tange ao tema bioético aborto, demonstrando também, a atuação do Estado brasileiro em relação a questão do aborto, entendido como um problema de saúde pública.

129 CABRERA, Oscar. PUCCIO, Luis Lamas. MICHEL, Agustina Ramón. CASAS, Lídia. CAVALLO, Mercedes. AHUMADA, Claudia. CASAS, Ximena. Los Derechos Reproductivos: Um debate necessário. I Congresso Lationoamericano Jurídico sobre Derechos Reproductivos. Arequipa, Perú. 5,6 y 7 de noviembre de 2009. 1ํo ed. Lima, Perú. Erre\&Erre artes Gráficas. 2011, p. 18.

$130 \mathrm{lbidem}$. p. 27. "Na medida em que apenas as mulheres podem abortar, a penalização do aborto se converte em uma disposição dirigida aos seus corpos e decisões, desta forma, as consequências da ilegalidade refletem em suas vidas e saúde." 


\section{CAPÍTULO II}

\section{CONTEXTUALIZAÇÃO HISTÓRICA E EVOLUTIVA DO DEBATE BIOÉTICO A RESPEITO DO ABORTO NO BRASIL E NO URUGUAI}

O debate Bioético, a respeito do tema aborto ${ }^{1}$, ganhou notória dedicação após o processo de redemocratização ocorrido na América Latina. Países como o Brasil e Uruguai viram correr em seus Parlamentos inúmeros projetos a respeito do tema.

Segundo estimativa apresentada pela Organização Mundial de Saúde (OMS), em média, 22 milhões de mulheres por ano, no mundo, se submetem a procedimentos abortivos taxados como inseguros, principalmente, em países não desenvolvidos. $^{2}$

$\mathrm{A} \mathrm{OMS}^{3}$, aponta ainda que, quanto menos restrição a procedimentos abortivos em um país, menor a taxa de abortos realizados e quanto maior a restrição, maior o número de abortos provocados e inseguros. ${ }^{4} \mathrm{O}$ mesmo estudo ainda apresenta o dado alarmante de que, uma em cada cinco gravidezes no mundo, finaliza com um aborto 5 .

Para a América Latina e caribe os dados são estimamos em 4,2 milhões de aborto inseguros, que colocam em risco a vida da mulher, realizados por ano. ${ }^{6}$ Segundo Diniz e Medeiros, no Brasil a situação é de ampla magnitude, afirmando que

\footnotetext{
${ }^{1}$ Entende-se por aborto a interrupção da gravidez que tanto pode advir de complicações na gestação quando ser provocada. Alguns obstetras delimitam esse termo para os episódios ocorridos até a 22은 semana da gravidez, após este período considera-se parto prematuro. REZENDE, M. Obstetrícia Fundamental. $11^{\circ} \mathrm{ed}$. Rio de Janeiro: Guanabara Koogan. 2008.

2 World Health Organization (WHO). Unsafe Abortion: Global and Regional Estimates of the Incidence of Unsafe Abortion and Associated Mortality in 2008. Geneva: WHO, 2011.

3 Ibidem.

${ }^{4}$ A definição de Aborto inseguro segundo a OMS é: um procedimento para terminar uma gravidez indesejada realizado por uma pessoa sem treinamento adequado para realiza-lo ou/e com ausência de atendimento médico.

${ }^{5}$ Este fato é explicado pela maneira como os países que regulamentaram o aborto tratam a questão. Em grande maioria, como no caso do Uruguai, o procedimento para a realização do aborto é acompanhado por um grupo de assistentes sociais e, na maioria das vezes, a gestante acaba desistindo do procedimento devido a atuação deste grupo de apoio. Nos países com restrição, como o Brasil, não há apoio psicossocial, sendo o aborto realizado na sobra de uma lei ineficaz tanto em prevenção como em repressão.

${ }^{6}$ lbidem.
} 
"o aborto é tão comum no Brasil que ao completar quarenta anos, mais de uma em cada cinco mulheres já o fizeram"7.

Apesar dos dados apresentados pelos pesquisadores e pela OMS, o tema ainda encontra profunda restrição no parlamento brasileiro. Em 2012 o Uruguai, após vários debates, conseguiu legislar a respeito do tema.

O debate a respeito da legalização ou criminalização do aborto ocorre nas esferas política e pública do Estado e da sociedade. O parlamento é o local de maior discussão, devido à recente redemocratização. Este fato se dá por ser o parlamento a instituição responsável pela elaboração e proposição de leis.

\subsection{DEBATE SOBRE O ABORTO NO BRASIL}

Neste subcapítulo será apresentado o contexto histórico do debate a respeito do aborto no Brasil, assim como a atual situação de sua discussão no plenário brasileiro. Será apresentada, portanto, no próximo tópico uma contextualização histórica quanto ao debate a respeito do aborto no Brasil.

\subsubsection{Contexto Histórico}

Ao analisar a contextualização histórica do debate a respeito do aborto no Brasil, é possível perceber dois fatos importantes: O primeiro, é a ênfase dada a este debate na história recente, principalmente após a redemocratização; o segundo, diz respeito a quantidade de propostas de lei apresentadas ao congresso.

Um dos primeiros projetos de leis apresentados no Brasil buscando legislar a respeito do aborto data de 1949. Proposto pelo Deputado Monsenhor Arruda Câmara, o referido projeto tinha por objetivo retirar do então código penal de 1940 as

7 DINIZ, Debora. MEDEIROS, Marcelo. Aborto no Brasil: uma pesquisa domiciliar com técnica de urna. Ciência e Saúde col. 2010: 15(1): 959-966. 
duas possibilidades de aborto contempladas pela lei, sendo elas, a gravidez oriunda de abuso e em situações de riscos a gestante. ${ }^{8}$

Este fato, pode ser considerado um marco para o tema no Brasil. A apresentação de sua proposta, logo após a queda do Estado Novo, sendo realizada por um membro da Igreja Católica - instituição que se tornaria um forte ator político iniciou um debate que se encontra ativo até os dias atuais. ${ }^{9}$

Este longo período de tempo, afirmam Rocha, Rostagnol e Guitiérrez, pode ser dividido em três etapas e algumas fases. ${ }^{10}$

Procedendo a discussão, encontra-se a etapa inicial, onde a primeira fase diz respeito ao final dos anos 1940 até meados de 1970, a qual possui uma discussão ainda imatura; na segunda fase, que percorre o período do início dos anos 1970 até os anos 1980, a participação no debate se restringia apenas aos atores sociais e políticos.

$\mathrm{Na}$ etapa de transição, houve uma intensificação do debate. Este fato se dá pelo período desta etapa, que se refere a boa parte da década de 1980. Década está, que ficou marcada pela assembleia constituinte e o retorno da democracia, após um longo período de Regime Militar, permitindo assim, uma maior participação dos atores políticos.

A terceira etapa é marcada pela consolidação do debate que, em sua primeira fase, percorre as legislaturas pós constituinte dos anos 1990. Possuindo inúmeras iniciativas de parlamentares que se identificavam com os ideais feministas e vários protestos de congressistas vinculados a grupos religiosos. A segunda fase, que se iniciou no final dos anos 1990, ainda está em seu desenrolar. Com o Debate consolidado no parlamento, surgem inúmeras iniciativas e projetos de parlamentares e grupos feministas, aderindo assim as tendências do momento. Em contrapartida, possui forte repressão por grupos religiosos, ainda fortemente representados no Congresso nacional.

Durante todas estás fases analisadas, até 0 ano de 2008, conforme afirmam Rocha, Rostagnol e Guitiérrez "foram apresentadas 109 (cento e nove)

\footnotetext{
8 "Art. 128. Não se pune o aborto praticado por médico: I - se não há outro meio de salvar a vida da gestante; II - se a gravidez resulta de estupro e o aborto é precedido de consentimento da gestante ou, quando incapaz, de seu representante legal. " BRASIL. Decreto-Lei 2.848, de 07 de dezembro de 194 0. Código Penal. Diário Oficial da União, Rio de Janeiro, 31 dez. 1940.

${ }^{9}$ ROCHA, Maria I. B. ROSTAGNOL, Susana. GUTIÉRREZ, M. Alicia. Aborto y Parlamento: um estúdio sobre Brasil, Uruguay y Argentina. R. bras. Est. Pop.. Rio de Janeiro. V.26, n. 2, 2009, p. 221. 10 Ibidem, p. 221.
} 
proposições. Incluindo projetos de lei, projetos de decretos legislativos e propostas de emenda constitucional" ${ }^{11}$, este número chegou a 206 (duzentos e seis). Atualmente encontram-se ativos na Câmara dos Deputados 58 (cinquenta e oito) processos e projetos de leis ${ }^{12}$ relativos ao tema aborto, em suas mais variadas formas criminalizando, regularizando, criando políticas públicas de prevenção, entre outros. ${ }^{13}$

Em sua maioria, as propostas dizem respeito a descriminalização do aborto. Este fato remete aos movimentos pós promulgação da Constituição da República Federativa do Brasil em 1988 (CRFB/88). Predominaram neste período, iniciativas de congressistas que se identificavam com os valores dos movimentos feministas, visando a prática do procedimento de aborto como um direito da mulher.

No ano de 2012, o Supremo Tribunal Federal (STF), em um debate histórico, proferiu decisão relevante para o tema, considerando legal o aborto de feto anencefálico ${ }^{14}$. Durante o processo de votação, o Ministro do STF, Luiz Fux, chegou a afirmar que "Impedir a interrupção da gravidez sob ameaça penal equivale à tortura". ${ }^{15}$

No próximo subcapítulo falaremos a respeito da atual situação do aborto no Brasil.

\subsubsection{O Aborto no Brasil}

Ainda que tenha sido considerado pelo Ministério da Saúde (MS) em 2009 como um problema de saúde pública, existe um grande vazio de informações sobre o

\footnotetext{
11 .Original "fueron presentadas 109 (cento e nove) proposições, incluyendo proyectos de ley, proyectos de decreto legislativo y propuesta de enmienda constitucional". Tradução do autor. ROCHA, Maria I. B. ROSTAGNOL, Susana. GUTIÉRREZ, M. Alicia. Aborto y Parlamento: um estúdio sobre Brasil, Uruguay y Argentina. R. bras. Est. Pop.. Rio de Janeiro. V.26, n. 2, 2009, p.222.

12 Lista em anexo.

13 Para maiores informações, pesquisa em: http://www.camara.gov.br/internet/sileg/Prop_lista.asp? formulario=formPesquisaPorAssunto\&Ass $1=$ aborto $\&$ co $1=+A N D+\& A s s 2=\& \operatorname{co} 2=+A N D+\& A s s 3=\& S u b m$ it2 $=$ Pesquisar $\&$ sigla $=\&$ Numero $=\& A n o=\& A u t o r=\&$ Relator $=\& \mathrm{dt} \mid \mathrm{nicio}=\& \mathrm{dtFim}=\&$ Comissao $=\&$ Situacao $=\&$ pesqAssunto $=1 \&$ OrgaoOrigem $=$ todos

14 Arguição de Descumprimento de Preceito Fundamental (ADPF) 54. Leia mais em: http://www.stf.jus.br/portal/cms/verNoticiaDetalhe.asp?idConteudo=204878

$15 \mathrm{http} / /$ g1.globo.com/brasil/noticia/2012/04/supremo-decide-por-8-2-que-aborto-de-feto-sem-cerebronao-e-crime.html
} 
aborto no Brasil, e o principal motivo é sua criminalização. ${ }^{16}$ Este fato atrapalha a obtenção de informações sobre o assunto, que por sua ilegalidade, traz medo aos indivíduos participantes em pesquisas de futuros problemas judiciais. As poucas pesquisas a respeito do tema, utilizaram de sistema de entrevistas sem identificação e método de urna, que permite a obtenção de resultados sem a identificação do indivíduo.

Apesar da proibição, a velocidade e facilidade em se realizar um aborto impressiona. Salientam, Diniz e Medeiros, autores da Pesquisa Nacional do Aborto $(\mathrm{PNA})^{17}$,

\begin{abstract}
O aborto é uma prática comum entre as mulheres, cujos saberes são compartilhados e mantidos como uma cultura reprodutiva feminina e sigilosa. Indiferentemente à lei penal, as mulheres abortam. Não sabemos como elas descrevem para si e para os outros a moralidade do aborto, mas a magnitude de que 1 em cada 5 mulheres já realizou ao menos um aborto nos mostra o quanto essa é uma prática comum na vida reprodutiva ${ }^{18}$
\end{abstract}

Esta inconsistência, entre a norma e a prática social é amplamente discutida pelo judiciário. Habermas esclarece que a norma tem um duplo aspecto de validade. Em primeiro ponto ela deve passar por um processo legislativo racional que a legitima pelo procedimento, em segundo a norma deve ter validade social, ou seja, ter aceitação pratica dos membros de determinada sociedade. ${ }^{19}$

É importante salientar que no aspecto normativo, as normas não devem, conforme afirma Machado20, "priorizar determinados valores ou crenças, mas sim representar o instrumento racional de estabilidade e regulamentar as ações sociais", ou seja, a norma deve ser algo reconhecido pela sociedade e não uma imposição. A autora ainda afirma que existe no Brasil

${ }^{16}$ BRASIL. Ministério da Saúde (MS). Aborto e Saúde pública no Brasil: 20 anos. (Série B. Textos Básicos de Saúde). Brasília: MS. 2009.

${ }^{17}$ A PNA é um levantamento por amostragem aleatória estratificada de domicílios que combinou duas técnicas de sondagem: a técnica de urna e questionários preenchidos por entrevistadoras.

18 LOYOLA, M. A. et al. Os autores respondem. Lacunas da Pesquisa Nacional do Aborto e Agenda para o Futuro. Ciência \& Saúde Coletiva, vol. 17, núm. 7, julio, 2012, pp. 1687-1688.

${ }_{19}$ HABERMAS, J. Direito e Democracia: Entre Facticidade e validade. V. 1. Rio de Janeiro: Tempo Brasileiro: 1997.

${ }^{20}$ MACHADO, Teresa Robichez de Carvalho. As consequências jurídicas e sociais da manutenção da criminalização do aborto. Ciênc. saúde coletiva, Rio de Janeiro, v. 17, n. 7, p. 1683-1685, July 2012 .Available from <http://www.scielo.br/scielo.php?script=sci_arttext\&pid=S1413$81232012000700004 \& \mid \mathrm{ng}=e n \& n r m=i s 0>$. access on 06 Sept. 2016. Pág. 1684. 
Uma cultura de aceitação das leis, seja por comodismo, seja por dogmas de natureza religiosa. Porém, tal aceitação não importa em ações concretas de seu cumprimento. Isso ocorre no caso da criminalização do aborto. Há uma certa aceitação de que o ato é criminoso. Entretanto, boa parte das mulheres ou recorrem a prática, ou conhece os meios e locais necessários para sua realização. ${ }^{21}$

Diniz e Medeiros mostram em sua pesquisa como é fácil o acesso ao aborto, demonstrando que este traz inúmeras consequências sociais e de saúde pública. ${ }^{22} \mathrm{O}$ fato é que a ilegalidade do aborto não impede que este seja realizado $\mathrm{e}$ implica em graves consequências à saúde de melheres.

Devido a sua ilegalidade, mulheres procuram os serviços de aborto clandestinos. Tais procedimentos, na maioria das vezes, possuem elevado risco à saúde da mulher. Conforme afirma Machado, "Esse fato somente será revertido caso o Estado brasileiro, democrático e laico, incorpore em suas normas jurídicas medidas de reconhecimento dos direitos sexuais e reprodutivos das mulheres" 23 .

Esta condição de ilegalidade do aborto no país, afirmam Farias e Cavalcanti, "além de todas as consequências danosas para a vida e a saúde das mulheres, também influi negativamente sobre os serviços de saúde, pois contamina inclusive $o$ atendimento realizado nos casos de aborto previsto em lei". ${ }^{24}$

Conforme afirmam os autores,

Isso ocorre em grande parte devido ao despreparo dos profissionais de saúde para lidar com as questões relacionadas ao abortamento, à violência sexual

\footnotetext{
${ }^{21}$ MACHADO, Teresa Robichez de Carvalho. As consequências jurídicas e sociais da manutenção da criminalização do aborto. Ciênc. saúde coletiva, Rio de Janeiro, v. 17, n. 7, p. 1683-1685, July 2012 .Available from <http://www.scielo.br/scielo.php?script=sci_arttext\&pid=S1413$81232012000700004 \&$ Ing=en\&nrm=iso >. access on 06 Sept. 2016. Pág. 1684.

22 DINIZ, Debora; MEDEIROS, Marcelo. Itinerários e métodos do aborto ilegal em cinco capitais brasileiras. Ciênc. saúde coletiva, Rio de Janeiro, v. 17, n. 7, p. 1671-1681, July 2012 . Available from <http://www.scielo.br/scielo.php?script=sci_arttext\&pid=S1413-81232012000700002\&lng=en\&nr m=iso>. access on 06 Sept. 2016.

${ }^{23}$ MACHADO, Teresa Robichez de Carvalho. As consequências jurídicas e sociais da manutenção da criminalização do aborto. Ciênc. saúde coletiva, Rio de Janeiro, v. 17, n. 7, p. 1683-1685, July 2012 .Available from <http://www.scielo.br/scielo.php?script=sci_arttext\&pid=S1413$81232012000700004 \&$ I ng=en\&nrm=iso >. access on 06 Sept. 2016. Pág. 1684.

${ }^{24}$ FARIAS, Rejane Santos; CAVALCANTI, Ludmila Fontenele. Atuação diante das situações de aborto legal na perspectiva dos profissionais de saúde do Hospital Municipal Fernando Magalhães. Ciênc. saúde coletiva, Rio de Janeiro, v. 17, n. 7, p. 1755-1763, July 2012 . Available from http://www.scielo.br/scielo.php?script=sci arttext\&pid=S1413$\underline{81232012000700014 \& \operatorname{lng}=\text { en\&nrm=iso }}$. access on 06 Sept. 2016.
} 
e doméstica e as relações de gênero, uma vez que os mesmos não recebem em sua formação profissional nenhum preparo e nem abordagem para lidar com esses temas que atualmente ganharam relevância no campo da saúde pública. ${ }^{25}$

Muitas vezes, por falta de conhecimento, os profissionais da saúde se deixam influenciar por fatores como o medo de sofrerem ações judiciais devido ao procedimento, desconhecimento da legislação vigente, medo de serem taxados como "aborteiros" e principalmente, por conceitos religiosos. ${ }^{26}$

Porém, salienta Galli, a recusa de profissionais da saúde em realizar a interrupção da gravidez pode ser considerada violência institucional, afetando as mulheres em sua autodeterminação sexual e reprodutiva, visto que, o direito a receber tratamento humanizado nos serviços de saúde está incluído no direito humano a viver livre de violência. ${ }^{27}$

De acordo com a OMS, o acesso ao atendimento é um fator essencial, configurando como um indicador de avaliação do desempenho dos sistemas de saúde.28

O debate acerca da necessidade de ampliação do acesso a esses serviços no Brasil colide na maioria das vezes com a discussão do aborto sob a ótica dos valores, da moral e da religião, deixando de ser discutida a partir de uma ótica humanística, mesmo quando diz respeito a uma gravidez decorrente do estupro. ${ }^{29}$

Conforme afirma Aquino,

${ }^{25}$ FARIAS, Rejane Santos; CAVALCANTI, Ludmila Fontenele. Atuação diante das situações de aborto legal na perspectiva dos profissionais de saúde do Hospital Municipal Fernando Magalhães. Ciênc. saúde coletiva, Rio de Janeiro, v. 17, n. 7, p. 1755-1763, July 2012. Available from http://www.scielo.br/scielo.php?script=sci arttext\&pid=S1413$81232012000700014 \&$ Ing=en\&nrm=iso . access on 06 Sept. 2016.

${ }_{26}$ Existe um estudo de Diniz e Madeiro que analisa os serviços de aborto legal oferecidos no Brasil. Para Maiores informações ler: MADEIRO, Alberto Pereira; DINIZ, Debora. Serviços de aborto legal no Brasil - um estudo nacional. Ciênc. saúde coletiva, Rio de Janeiro , v. 21, n. 2, p. 563-572, Feb. 2016 .Disponível em: <http://www.scielosp.org/scielo.php?script=sci_arttext\&pid=S1413$81232016000200563 \&$ Ing=en\&nrm=iso $>$. access on 06 May 2017. http://dx.doi.org/10.1590/141381232015212.10352015.

${ }^{27} \mathrm{GALLI}$, Beatriz. Violência sexual, gravidez indesejada e acesso ao aborto legal: uma abordagem de direitos humanos e igualdade de gênero. Revista de Saúde Sexual e Reprodutiva, Rio de Janeiro, n. 19, 2005.

${ }^{28}$ WORLD HEALTH ORGANIZATION (WHO). World reporto $\mathbf{n}$ violence and health. Geneva: WHO. 2002.

${ }^{29}$ LEOCÁDIO, E.M.A. Aborto pós-estupro: uma trama (des) conhecida entre o direito e a política de assistência à saúde da mulher [dissertação]. Distrito Federal: Universidade de Brasília. 2006. 
São constantes as denúncias do movimento de mulheres acerca de problemas enfrentados pelas usuárias de serviços de saúde, incluindo desde a dificuldade de acesso a uma vaga até situações de discriminação sofridas durante a internação ${ }^{30}$

Apesar de ser considerado um grave problema de saúde pública no Brasil, os dados a respeito do assunto impressionam pela magnitude do tema, de sua ocorrência e pelas complicações à saúde. Devido a sua ilegalidade, procedimentos clandestinos de alta periculosidade são realizados por "baixo dos lençóis" da sociedade. Segundo esclarece Villela et al,

\begin{abstract}
A ilegalidade e a insegurança que cercam a realização do aborto implicam no recurso a uma diversidade de práticas. Estas são escolhidas de acordo com o acesso da mulher e à sua possibilidade de lidar com os eventuais efeitos adversos do método adotado. Esta utilização de diferentes meios para interromper a gravidez, mesmo quando estes implicam em risco à saúde, mostra a determinação da mulher em relação à sua escolha, mais uma vez sugerindo a necessidade da discussão do direito ao aborto com base no pressuposto do direito à saúde. ${ }^{31}$
\end{abstract}

De acordo com OMS, seguindo estes padrões de ilegalidade, o aborto provocado coloca em risco a vida da gestante, em decorrência das precárias condições que são realizados ${ }^{32}$, propiciando ainda, o fortalecimento do mercado clandestino de serviços abortivos, o que favorece o aumento dos de alto risco. ${ }^{33}$

${ }^{30}$ AQUINO, Estela M. L. et al . Qualidade da atenção ao aborto no Sistema Único de Saúde do Nordeste brasileiro: o que dizem as mulheres?. Ciênc. saúde coletiva, Rio de Janeiro, v. 17, n. 7, p. 1765-1776, July 2012 Available from <http://www.scielo.br/scielo.php?script=sci_arttext\&pid=S1413-812320120 $00700015 \& \operatorname{lng}=$ en\&nrm=iso $>$. access on 06 Sept. 2016.

31 VILLELA, Wilza Vieira et al. Motivos e circunstâncias para o aborto induzido entre mulheres vivendo com HIV no Brasil. Ciênc. saúde coletiva, Rio de Janeiro, v. 17, n. 7, p. 1709-1719, July 2012 Available from <http://www.scielo.br/scielo.php?script=sci_arttext\&pid=S1413$81232012000700009 \& \ln \mathrm{g}=\mathrm{en \& nrm}=\mathrm{iso}>$. access on 06 Sept. 2016.

32 ORGANIZAÇÃO MUNDIAL DA SAÚDE (OMS). Abortamento seguro: Orientação técnica e de políticas para os sistemas de saúde. Genebra: OMS. 2004.

${ }_{33}$ KULCZYCKI, A. De eso no se habla: aceptando el aborto em México. Estudios demográficos y urbanos. 18(2). 2003. Pág. 353-386. 
Segundo os dados obtidos pela Pesquisa Nacional do Aborto (P.N.A.), 20\% (Vinte por cento) das mulheres, ao chegarem a final do período reprodutivo, terão realizado pelo menos um processo abortivo. ${ }^{34}$

Em conformidade com Monteiro e Adesse, em um estudo realizado tendo como base registros hospitalares de internações oriundas de procedimentos de aborto, chegou-se ao número 1.054.242 abortos inseguros, fato este que corresponde à média de 30 abortos para cada 100 nascidos vivos o que leva a taxa de 20,7 em cada 1000 mulheres entre 15 e 49 anos realizaram algum procedimento abortivo. ${ }^{35}$

Segundo dados sobre internações do Sistema Único de Saúde (S.U.S.), depois do parto, a curetagem ${ }^{36}$ pós aborto é o procedimento obstétrico mais realizado nos hospitais públicos do Brasil. Tendência que pode ser observada nos países onde o aborto também é criminalizado. ${ }^{37}$

Diniz e Medeiros ${ }^{38}$, em sua pesquisa, realizada em $2010^{39}$, chegaram a estimativa de que $22 \%$ (vinte e dois por cento) das mulheres na faixa de 35 a 39 anos declaravam já ter realizado algum procedimento abortivo. Neste mesmo ano, foram registrados o número de 220.571 internações resultantes de complicações oriundas de procedimentos de aborto clandestino. Em uma pesquisa realizada 2002 nas capitais brasileiras e no Distrito Federal ${ }^{40}$, ficou evidenciado que $11,4 \%$ dos óbitos

${ }^{34}$ DINIZ, D. MEDEIROS, M. Aborto no Brasil: uma pesquisa domiciliar com a técnica de urna. Ciência e Saúde Coletiva. 15(1). 2010. Pág. 960.

${ }^{35}$ MONTEIRO, M. F. G. ADESSE, L. Estimativas de aborto induzido no Brasil e Grandes Regiões (1992 - 2005). In: Encontro Nacional de Estudos Populacionais. 15. Anais...Caxambu, Abep. 2006.

${ }^{36}$ A curetagem é um procedimento médico executado em unidade hospitalar, seu objetivo é retirar material placentário ou endometrial da cavidade uterina por um instrumento denominado cureta. Tem como função principal limpar os restos do aborto. ABCMED, 2015. Curetagem uterina: o que é? Para que serve? Quando uma mulher deve fazer?. Disponível em: <http://www.abc.med.br/p/exames-eprocedimentos/804884/curetagem-uterina-o-que-e-para-que-serve-quando-uma-mulher-deve-

fazer.htm>. Acesso em: 4 mai. 2017.

${ }^{37}$ SINGH, S. MONTEIRO, M. LEVIN, J. Trends in hospitalization for abortion complications and the potential impacto $f$ misoprostol use: the case of Brazil. In: IUSSP Seminar os the Health, Social and Economic Consequences os Unsafe Abortion. México. 2010.

38 DINIZ, Debora; MEDEIROS, Marcelo. Aborto no Brasil: uma pesquisa domiciliar com técnica de urna. Ciênc. saúde coletiva, Rio de Janeiro, v. 15, supl. 1, p. 959-966, June 2010. Available from http://www.scielo.br/scielo.php?script=sci arttext\&pid=S1413-81232010000700002\&lng=en\&nrm=iso . access on 08 Sept. 2016, p. 962.

39 A pesquisa foi atualizada em 2016, porém, apresentou dados semelhantes. O principal ponto apresentado na P.N.A. 2016 foi o alarmante número de, aproximadamente, 503 mil abortos realizados em 2015. Para maiores informações DINIZ, Debora; MEDEIROS, Marcelo; MADEIRO, Alberto. Pesquisa Nacional de Aborto 2016. Ciênc. saúde coletiva, Rio de Janeiro, v. 22, n. 2, p. 653-660, Feb. 2017. Disponível em : <http://www.scielo.br/scielo.php?script=sci_arttext\&pid=S141381232017000200653\&lng=en\&nrm=iso >. access on 06 May 2017. http://dx.doi.org/10.1590/141381232017222.23812016.

40 LAURENTI, Ruy; JORGE, Maria Helena Prado de Mello; GOTLIEB, Sabina Léa Davidson. A mortalidade materna nas capitais brasileiras: algumas características e estimativa de um fator de ajuste. Rev. bras. epidemiol., São Paulo, v. 7, n. 4, p. 449-460, Dec. 2004. Available from 
maternos registrados, eram oriundos de complicações advindas do aborto. A contraponto, é reconhecido que estas são as causas de morte mais mal declaradas no SUS ${ }^{41}$.

Conforme afirma Leal, a escolha pelo aborto envolve vários fatores,

A negociação entre o feminino e o masculino, a definição de papéis sociais, é mediada fundamentalmente pelo projeto de ter um filho ou de estar grávida. O reconhecimento mesmo do fato de que se 'está grávida' depende de uma intensa negociação entre o casal e a família extensa. É somente após a concepção que a gravidez pode vir a ser reconhecida (ou não) enquanto tal. A gravidez, se reconhecida, pode funcionar como uma estratégia de aliança, especialmente feminina. Fica claro o poder que a mulher (ou a família da mulher) passa a ter sobre o homem com o evento da gravidez, no sentido de pressionar o homem a juntar-se a ela, que em uma nova união (consensual ou oficial) ou na reestruturação de uma união já existente. A Gravidez, quando reconhecida, estabelece, por sua vez, outra intensa negociação sobre quem irá assumir o projeto de uma gravidez ou ter um filho. Uma gravidez não reconhecida como tal abre a possibilidade de um aborto, mas este agora empreendido como um método anticoncepcional, algo que pode ser empregado após a negociação.

[...]

A gravidez é também pensada como um risco, como algo que pode ou não ocorrer, algo incluído no universo dos eventos aleatórios. Com relação à ideia de risco, não é mera coincidência que o termo usado para engravidar; a saber, pegar filho, seja o mesmo que pegar uma doença ou ser vítima de uma aflição.

[...]

A inclusão do aborto induzido entre as alternativas anticoncepcionais deve ser compreendida a partir desta lógica do evento aleatório, uma espécie de escolha racional 'nativa' ou êmica, para usar o jargão antropológico.(Grifo Nosso $)^{42}$

A autora ainda afirma que,

'Estar grávida' ou 'assumir um filho' é sempre um processo de negociação social da realidade da mulher, onde as situações de aliança e de manutenção

http://www.scielo.br/scielo.php?script=sci arttext\&pid=S1415-790X2004000400008\&lng=en\&nrm=iso . access on 08 Sept. 2016.

${ }^{41}$ MENEZES, Greice; AQUINO, Estela M. L.. Pesquisa sobre o aborto no Brasil: avanços e desafios para o campo da saúde coletiva. Cad. Saúde Pública, Rio de Janeiro, v. 25, supl. 2, p. s193-s204, 2009. Available from <http://www.scielo.br/scielo.php?script=sci_arttext\&pid=S0102-311X2009001400002\&l ng=en\&nrm=iso $>$. access on 08 Sept. 2016.

42 LEAL, Ondina Fachel. "Levante a mão aqui quem nunca tirou criança!": revisitando dados etnográficos sobre a disseminação de práticas abortivas em populações de baixa-renda no Brasil. Ciênc. saúde coletiva, Rio de Janeiro, v. 17, n. 7, p. 1689-1697, July 2012 . Available from http://www.scielo.br/scielo.php?script=sci arttext\&pid=S1413-81232012000700007\&lng=en\&nrm=iso access on 08 Sept. 2016, p. 1693. 
financeira e moral do projeto reprodutivo (biológico e social) tornam-se condições prévias e estratégias de reconhecimento social de um estado definido e definidor de gravidez. ${ }^{43}$

É importante salientar que, a recusa da mulher em ser mãe por escolha própria e não por injunções da vida é um dos fatores que pode ser considerado primordiais a rejeição do aborto, visto que, desafia os modelos patriarcais e religiosos de organização da sociedade. ${ }^{44}$

No tópico seguinte faremos uma analise a respeito do debate sobre o aborto no Uruguai.

\subsection{DEBATE DO ABORTO NO URUGUAI}

Neste subcapítulo apresentaremos o contexto histórico do aborto no Uruguai, analisando o seu desenrolar, evolução e implementação. Por último apresentaremos a atual situação do aborto neste país.

\subsubsection{Contexto Histórico}

Neste subcapítulo analisaremos o contexto histórico do aborto no Uruguai, seu desenrolar no tempo e principais modificações normativas a seu respeito.

43 LEAL, Ondina Fachel. "Levante a mão aqui quem nunca tirou criança!": revisitando dados etnográficos sobre a disseminação de práticas abortivas em populações de baixa-renda no Brasil. Ciênc. saúde coletiva, Rio de Janeiro, v. 17, n. 7, p. 1689-1697, July 2012 . Available from http://www.scielo.br/scielo.php?script=sci arttext\&pid=S1413-81232012000700007\&lng=en\&nrm=iso access on 08 Sept. 2016, p.1695.

${ }^{4}$ CARVALHO Apud VILLELA, Wilza Vieira et al. Motivos e circunstâncias para o aborto induzido entre mulheres vivendo com HIV no Brasil. Ciênc. Saúde coletiva, Rio de Janeiro, v. 17, n. 7, p. 1709-1719, July 2012. Available from <http://www.scielo.br/scielo.php?script=sci_arttext\&pid=S1413812320120 00700009\&lng=en\&nrm=iso $>$. access on 08 Sept. 2016. 
O Uruguai é um país pequeno da América do Sul, com uma população estimada em 3,3 milhões de pessoas, das quais 95\% são residentes em áreas urbanas $^{45}$ e $52 \%$ são mulheres. ${ }^{46}$

No que diz respeito ao debate bioético do aborto, o Uruguai pode ser considerado um dos pioneiros e com uma trajetória distinta, em relação a outros países. Isto porque, o aborto foi considerado legal no Uruguai entre os anos de 1934 e 1938, antecedido apenas pela antiga e extinta União Soviética que havia realizado a sua regularização em 1920. Esta regulamentação do aborto no Uruguai, segundo o consentimento de alguns autores, se deu como o reconhecimento de este ser o principal método contraceptivo desta época. ${ }^{47}$

Em 1938 o aborto volta a ser penalizado no Uruguai. A nova lei instalou um sistema que não permitia o aborto, abrindo, portanto, um sistema clandestino, com condições insalubres, e métodos muitas vezes pouco ortodoxos, colocando em risco a vida da mulher. ${ }^{48}$

Com o desenrolar do século XX, as restrições sobre o aborto fizeram sua pratica se tornar "secreta". No decorrer dos anos 1990, era comum os médicos denunciarem mulheres que recorriam ao sistema de saúde por complicações pósaborto, porém, dificilmente haviam consequências penais. Este fato se dá pelo contexto cultural do Uruguai, que de certa forma sempre foi de "condenar, tolerar e negar". Este contexto, durante do desenrolar da virada do século foi o lugar de sucessivos debates parlamentares sobre projetos de lei de regulamentação do aborto. 4950

Em meados de 1978 a 1979, durante o Regime Militar uruguaio, foi apresentada uma proposta de regularização do aborto, propondo o aborto voluntario

45 UNICEF. Observatorio de los Derechos de la Infancia y la Adolescencia em Uruguay. Álvaro Arroyo et al. Montevideo: UNICEF. 2012.

46 INE. Anuario estadístico 2014. Montevideo. 2014. Acessado em 08 de setembro de 2016 em <http://www.ine.gub.uy/documents/10181/37281/Anuario2014.pdf/021afc83-e6c9-43c9-8a7e-302f7a5 eeed6>.

${ }^{47}$ SAPRIZA, G. Historia de la (des)penalización del aborto em Uruguay."Aborto libre": La corta experiência uruguaya (1934-1938). In NIKI, J. et al. (Des)penalización del aborto em Uruguay: Prácticas, actores y discursos, Abordaje interdisciplinario sobre uma realidade compleja. UdelaR. 2011. 48 ABRACINSKAS, L. LÓPEZ GÓMES, A. Mortalidad materna, aborto y salud em Uruguay: um escenario cambiante. Montevideo: MYSU. 2004.

49 ROSTAGNOL, S. Complicaciones post-aborto como uma etapa del processo del aborto: los distintos actores involucrados. In: Foro por los Derechos Reprodutivos, Seminario Regional sobre Monitoreo de la Atención de las Complicaciones post aborto em Hospitales Públicos em Áreas Urbanas. Buenos Aires: 21-22 Abril. 2003.

50 SANSEVIERO, R. Condena, Tolerancia y Negación. El Aborto em Uruguay. Montevideo: CIIIP. 2003 
até o período máximo de 12 semanas de gestação. O projeto foi analisado e, posteriormente, descartado pelos militares. ${ }^{51}$

Entre 1984 e 1985, grupos feministas apresentam o tema para a Concertación Nacional Programática, que procurava derrubar a ditadura, porém, devido ao contexto da causa o tema não foi aceito. ${ }^{52}$

Em 1985, já pós ditadura, foi proposto ao Parlamento, por deputados do partido "Colorado" a volta da despenalização de 1934. O Debate não prosperou. Nos anos de 1993 a 1994 foi apresentado um projeto de lei regulamentando o aborto, por consentimento da mulher, nas primeiras 12 semanas e além deste tempo em caso de a gravidez ser considerada um risco à saúde da mulher. $\mathrm{O}$ debate foi aprovado pela Comissão de Bioética da câmara dos Deputados, porém, o debate não chegou ao plenário. ${ }^{53}$

Em 1998, o projeto apresentado em 1993 é novamente proposto, com novas modificações e exposição de motivos. Entre os anos de 2002 a 2004, importantes modificações aconteceram. Em 2002 é aprovado na câmara dos deputados o projeto de lei de Defensa de la Salud Reprodutiva, porém, um ano e meio depois o senado vota contra a promulgação da lei. Em 2001, um considerável aumento de morte de gestantes devido a complicações pós abortos clandestinos leva a comunidade médica a realizar estudos que contribuíssem para a diminuição deste índice. ${ }^{54}$

Este ato acaba por despertar os grupos feministas, que desarquivam o projeto de lei a respeito do tema e desempenhando uma forte atuação no parlamento, movimentam os grupos a seu favor, ampliando sua base de apoio. ${ }^{55}$

O movimento médico acabou por desencadear três importantes fatores: Primeiro foi que o movimento médico atuou como um fator chave para a legalização do aborto; segundo, foi que isto permitiu o desenvolvimento de políticas públicas focadas no atendimento de internações causadas por procedimentos abortivos inseguros e; terceiro, derivado dos demais, proporcionou que o tema viesse a debate,

51 ROCHA, Maria Isabel Baltar da; ROSTAGNOL, Susana; GUTIERREZ, María Alicia. Aborto y Parlamento: un estudio sobre Brasil, Uruguay y Argentina. Rev. bras. estud. popul., São Paulo, v. 26 , n. 2, p. 219-236, Dec. 2009 Available from http://www.scielo.br/scielo.php?script=sci arttext\&pid=S 0102-30982009000200005\&lng=en\&nrm=iso. access on 09 Sept. P. 225

52 Ibidem. P. 225

53 Ibidem.

${ }^{54}$ Ibidem. P. 225-226

55 lbidem. P.226 
permitindo que mulheres falassem a respeito do aborto com seus médicos sem medo de consequências legais maiores. ${ }^{56}$

Em 2004, visto o fracasso da tentativa de legalizar o aborto, o Ministerio de Salud Pública (M.S.P.) aprova uma normativa dedicando mais atenção ao tema. Esta normativa permite diminuir a possibilidade de óbito em procedimentos de aborto, porém, abre a discussão a respeito da utilização do misoprosto| ${ }^{57}$ como medicamento abortivo reafirmando a penalização. ${ }^{58}$

Em 2007 a 2008 um novo projeto é apresentado ao Senado, com muitas poucas modificações dos projetos anteriores. É importante salientar que, a sanção pela realização do aborto no Uruguai só era praticada em caso de o procedimento levar a gestante a óbito. ${ }^{59}$

As estatísticas sobre o aborto no Uruguai nos mostram que, entre os anos de 1989 e 1997 houve uma média de 13,7 processos penais por ano, devido ao crime de aborto. Em 2000 e 2001 esta média foi de 16. Isto significa que esta média corresponde a $0,04 \%$ dos abortos realizados, visto que, a estimativa para este período é de 33.000 abortos por ano. 60

O debate reiniciado em 2007 foi intensificado com a discussão a respeito da nova lei de Salud Sexual y Reproductiva (Lei 18.426). Logo após ser aprovado em 2008, um veto presidencial derruba os artigos da referida lei, que permitiam a mulher o direito de decidir a respeito da interrupção da gravidez. ${ }^{61}$

56 ROCHA, Maria Isabel Baltar da; ROSTAGNOL, Susana; GUTIERREZ, María Alicia. Aborto y Parlamento: un estudio sobre Brasil, Uruguay y Argentina. Rev. bras. estud. popul., São Paulo, v. 26, n. 2, p. 219-236, Dec. 2009 Available from http://www.scielo.br/scielo.php?script=sci arttext\&pid=S 0102-30982009000200005\&lng=en\&nrm=iso. access on 09 Sept. P. 226

57 "O misoprostol, análogo sintético da prostaglandina $\mathrm{E}$, foi introduzido no Brasil em 1984 pelo laboratório Searle, com o nome comercial de Cytotec®. Embora licenciado para o tratamento de úlcera gástrica e duodenal, logo ganhou popularidade como abortifaciente". MENGUE, Sotero Serrate; DAL PIZZOL, Tatiane da Silva. Misoprostol, aborto e malformações congênitas. Revista brasileira de ginecologia \& obstetrícia. Rio de Janeiro. Vol. 30, n. 6 (jun. 2008), p. 271-273, 2008. P. 271.

58 ROCHA, Maria Isabel Baltar da; ROSTAGNOL, Susana; GUTIERREZ, María Alicia. Aborto y Parlamento: un estudio sobre Brasil, Uruguay y Argentina. Rev. bras. estud. popul., São Paulo, v. 26, n. 2, p. 219-236, Dec. 2009 Available from http://www.scielo.br/scielo.php?script=sci arttext\&pid=S 0102-30982009000200005\&lng=en\&nrm=iso. access on 09 Sept. p.. 226.

59 lbidem. P. 226.

60 SANSEVIERO, R. Condena, Tolerancia y Negación. El Aborto em Uruguay. Montevideo: CIIIP. 2003

61 FERRE MENZA, Zuleika. Evaluación de la despenalización del aborto en Uruguay em la fecundidade adolescente / Zuleika Ferre Menza. Tesis Maestria em Demografía y Estudios de Poblacións. Montevideo: UR.FCS. Unidad Multidisciplinaria. Programa de Población. 2015. P. 13. 
No final de 2011 é reiniciado o debate sobre a despenalização do aborto na câmara dos deputados, sendo aprovado e sancionada em $2012 .{ }^{62}$ Conforme esclarece Ferre Menza o processo para se abortar não é tão simples, existe todo um procedimento.

La Ley 18.987 permite la IVE ${ }^{63}$ dentro de las primeras 12 semanas de gestación, durante las cuales la mujer deberá comparecer ante uma comisión integrada por al menos tres profesionales de los cuales uno deberá ser médico ginecólogo, outro especializado em el área de la salud psíquica y el tercero em el área social. Los profesionales debem explicarle los alcances de su decisión (riesgos inherentes a la práctica, alternativas al aborto provocado incluyendo los programas disponibles de apoyo social, económico y adopción, asesorarla para prevenir embarazos futuros, etc.) y la mujer debe informar sobre 'las circunstancias derivadas de las condiciones em que ha sobrevenido la concepción, situaciones de penúria económica, sociales o familiares o etarias que a su criterio, le impiden continuar con el embarazo em curso' (artículo 2, Ley 18.987). Luego de um período de reflexión de cinco días, la mujer informa su decisión e em caso de ratificar su voluntad de interrumpir el embarazo ante el médico ginecólogo tratante, se le coordina de inmediato el procedimiento. En el caso de mujeres menores de 18 años, em la medida que el equipo interdisciplinario considere que tiene autonomia progresiva, pueden solicitar y consentir el procedimento sin la opinión de sus padres. ${ }^{64}$

No próximo subcapítulo analisaremos a atual situação do Uruguai em relação ao aborto no período pós regulamentação do I.V.E.

62 FERRE MENZA, Zuleika. Evaluación de la despenalización del aborto en Uruguay em la fecundidade adolescente / Zuleika Ferre Menza. Tesis Maestria em Demografía y Estudios de Poblacións. Montevideo: UR.FCS. Unidad Multidisciplinaria. Programa de Población. 2015. P. 13. 63 Interrupción Voluntaria del Embarazo (I.V.E.).

64 "A lei 18,987 permite a Inter I.V.E dentro das primeiras 12 semanas de gestação, durante as quais a mulher deverá comparecer perante uma comissão integrada por ao menos três profissionais dos quais um deverá ser médico ginecologista, outro especialista na área de saúde psíquica e o terceiro na área de serviço social. Os profissionais devem explicar as consequências de sua decisão (riscos inerentes a prática, alternativas ao aborto provocado incluindo os programas disponíveis de apoio social, econômico e de adoção, assessoramento para prevenção de abortos futuros, etc) e a mulher deve informar sobre 'as circunstancias derivadas das condições de sobrevivência para a concepção, situações econômicas, sociais, familiares, ou etárias que a seu critério lhe impedem de continuar com a gravidez em curso' (artigo 2, lei 18.987). Depois de um período de reflexão de cinco dias, a mulher informa sua decisão e em caso de ratificar sua vontade de interromper a gravidez frente ao médico ginecologista responsável, se executa de imediato o procedimento. No caso de mulheres menores de 18 anos, e na medida que a equipe interdisciplinar julgue que esta não tenha autonomia para prosseguir, podem solicitar o consentimento do procedimento aos seus pais." FERRE MENZA, Zuleika. Evaluación de la despenalización del aborto en Uruguay em la fecundidade adolescente / Zuleika Ferre Menza. Tesis Maestria em Demografía y Estudios de Poblacións. Montevideo: UR.FCS. Unidad Multidisciplinaria. Programa de Población. 2015. P. 13. 


\subsubsection{O Aborto no Uruguai}

Após a entrada em vigor da lei do aborto em dezembro de 2012 no Uruguai até novembro de 2013 foram registrados a realização de 6.676 I.V.E. ${ }^{65}$, de acordo com o informado pelo Sistema Nacional de Información (SINAdl) del Ministerio de Salud Pública (M.S.P.) em 2014 foram registrados 8.500 IVE o que implica em uma média de 12 para cada mil mulheres com idade entre 15 e 45 anos. ${ }^{66}$

É notável a mudança de valores, de uma base anual de 33.000 abortos para 8.500. O número de mulheres que desistiram do aborto em 2014 aumentou 30\%, isto mostra como a lei, acompanhada da atuação do MSP está sendo efetiva. Esta média alcançada pelo Uruguai de 12 por 1.000 está abaixo do nível mundial em países nórdicos ${ }^{67}$.

Um fator importante para a regulamentação do I.V.E. no Uruguai, foi o processo de redemocratização, que criou condições para a ampliação do debate na sociedade, possibilitando a discussão no parlamento e no poder judiciário, o que levou a criação de normas e políticas públicas para a área da saúde. ${ }^{68}$

No próximo tópico apresentaremos os principais métodos de realização de aborto e suas consequências.

\subsection{O ABORTO CLANDESTINO - MÉTODOS}

Abordaremos agora os principais métodos abortivos utilizados em ambos os países e suas consequências no decorrer do procedimento.

\footnotetext{
${ }^{65}$ BALANCE 1er ANO DE IMPLEMENTACION DE LEY 18.987 -INTERRUPCION VOLUNTARIA DEL EMBARAZO DECRETO 375/012 REGLAMENTACION DE LA LEY DE IVE (http://www.msp.gub.uy/sites/default/files/archivos_adjuntos/conferencia\%20prensa\%20IVE\%20FEBR ERO\%202014.pdf).

${ }^{66}$ Para maiores informações consultar em: <http://www.msp.gub.uy/noticia/interrupci\%C3\%B3n-volunt aria-de-embarazo> Acesso em 20 de outubro de 2016.

$67 \mathrm{https}: / /$ noticias.terra.com.br/mundo/america-latina/uruguai-apos-legalizacao-desistencia-de-abortossobe-30,2e4163764976c410VgnCLD200000b1bf46d0RCRD.html. Acesso em 20 de outubro de 2016. 68 Para maiores informações a respeito do aborto pelo mundo consultar https://www.reproductiverights.org/es/document/leyes-sobre-aborto-en-el-mundo-de-2014
} 
Alguns estudos realizados na última década concluíram que o principal método abortivo atualmente utilizado é 0 uso do medicamento Cytotec ${ }^{69}$. Originalmente desenvolvido para tratamento de úlcera gástrica seu princípio ativo misoprostol - induz ao aborto. ${ }^{70}$

Conforme pode ser verificado em alguns estudos ${ }^{71}$, nos anos de 1990 houve uma significativa mudança com a entrada do Cytotec no mercado. ${ }^{72}$ Uma queda relativa na mortalidade materna e um aumento significativo no número de internações hospitalares para a finalização do aborto mostra que, "A Realidade conhecida é que as mulheres iniciam o aborto com uso do Cytotec e o finalizam nos hospitais públicos com a curetagem" 73 .

Conforme esclarecem Diniz e Medeiros, existe uma variedade de métodos ainda utilizados.

\begin{abstract}
Há uma diversidade no que as mulheres descrevem como chás, líquidos e ervas. Além das variações regionais, existem particularidades nas doses e nos regimes de uso na etapa de preparação do corpo para o aborto ou no que ainda é descrito como regulação da menstruação. O chá mais comum foi o da buchinha-do-norte, tido como poderoso para descer a menstruação por uma em cada oito mulheres. Em seguida está a arruda, a sena e o boldo, em combinação com outros líquidos ou diluídos isoladamente em água, sem uso de açúcar ou adoçantes. Há receitas complexas que combinam diferentes ervas, líquidos, medicamentos e temperos, como, por exemplo, coca-cola quente com sonrisal, pimenta do reino, sena e cidreira, ou, ainda, parapiroba com canela, aspirina e melhoral. O regime de uso é oral em doses alternadas ou combinadas às refeições, ou mesmo em total jejum. A eficácia da erva pode ser isolada ou combinada a coca-cola quente (em todas as cidades), cachaça (Salvador) ou vinho (Porto Alegre). Medicamentos como anador, sonrisal ou melhoral foram muito comuns em combinação com as ervas, em
\end{abstract}

69 FONSECA, Walter et al. Características sócio-demográficas, reprodutivas e médicas de mulheres admitidas por aborto em hospital da Região Sul do Brasil. Cad. Saúde Pública, Rio de Janeiro, v. 14, n.2, p.279-286. $1998 . \quad$ Available from http://www.scielo.br/scielo.php?script=sci_arttext\&pid=S0102-

311X1998000200012\&lng=en\&nrm=iso >. access on 12 Sept. 2016.

70 NADER, Priscilla Rocha Araújo; BLANDINO, Vanez da Rocha Panetto; MACIEL, Ethel Leonor Nóia. Características de abortamentos atendidos em uma maternidade pública do Município da Serra - ES. Rev. bras. epidemiol., São Paulo, v. 10, n. 4, p. 615-624, Dec. 2007. Available from $<$ http://www.scielo.br/scielo.php?script=sci_arttext\&pid=\$1415-790X2007000400019\&lng=en\&nrm=is o>. access on 12 Sept. 2016.

71 Obras Citadas em notas 65 e 66.

72 HARDY, Ellen; ALVES, Graciana. Complicações pós-aborto provocado: fatores associados. Cad. Saúde Pública, Rio de Janeiro, v. 8, n. 4, p. 454-458, Dec. 1992. Available from $<$ http://www.scielo.br/scielo.php?script=sci_arttext\&pid=S0102-311X1992000400010\&lng=en\&nrm=is o>. access on 12 Sept. 2016.

73 DINIZ, Debora; MEDEIROS, Marcelo. Itinerários e métodos do aborto ilegal em cinco capitais brasileiras. Ciênc. saúde coletiva, Rio de Janeiro, v. 17, n. 7, p. 1671-1681, July 2012 . Available from <http://www.scielo.br/scielo.php?script=sci_arttext\&pid=S1413-81232012000700002\&lng=en\&nr $\mathrm{m}=$ iso $>$. access on 12 Sept. 2016. P. 1672. 
particular aquelas que provocavam alterações estomacais, como a buchinha, a sena, a arruda ou a caboclinha. O medicamento mais comum utilizado em combinação com as ervas foi a aspirina (e suas variações), cujo poder de sangramento no caso da dengue, segundo as mulheres, faria descer a menstruação. Alguns produtos tradicionais vendidos em farmácias, como o "regulador Xavier", foram incluídos na lista das ervas ou líquidos utilizados. ${ }^{74}$

\begin{abstract}
A respeito do uso do Cytotec os pesquisadores apresentaram em seu trabalho "Itinerários e métodos do aborto ilegal em cinco capitais brasileiras" os seguintes dados a respeito do seu uso
\end{abstract}

\begin{abstract}
O principal método utilizado para abortar foi o cytotec isolado ou o cytotec combinado com chás, líquidos e ervas $(52 \%, 64)$, seguido de curetagem em clínica privada $(36 \%, 44)$. A finalização do aborto sem recurso à internação hospitalar foi vivida pela maioria das mulheres $(64 \%, 78)$, corroborando em parte suposições utilizadas em estimativas indiretas de magnitude do aborto15. Duas em cada três mulheres abortaram sem recurso à internação hospitalar. Entre as que utilizaram o cytotec como método único, 47\% (28) não precisaram ser internadas para finalizar o aborto. Das que abortaram em clínicas privadas, 93\% (41) não necessitaram de internação hospitalar. Considerando todos os métodos, para cada mulher branca internada para finalizar o aborto, foram internadas três negras.

Das 31 mulheres que utilizaram o cytotec como método único e foram internadas em hospitais para finalizar o aborto, $52 \%$ (16) usaram quatro comprimidos; 29\% (9) usaram dois comprimidos; $10 \%$ (3) usaram seis ou mais comprimidos; $6 \%$ (2) usaram um comprimido e $3 \%$ (1) usaram cinco comprimidos. A dose do cytotec utilizada pelas mulheres que não precisaram ficar internadas não sofreu grandes alterações: $54 \%$ (15) usaram quatro comprimidos; $21 \%$ (6) usaram três comprimidos; $11 \%$ (3) usaram seis ou mais comprimidos; $7 \%$ (2) usaram um comprimido; $4 \%$ (1) usaram cinco comprimidos e $4 \%$ (1) não se recordavam da dose utilizada. Todas as mulheres se recordavam do regime de uso e administração do cytotec: $81 \%$ (52) delas fizeram uso vaginal e oral; $17 \%$ (11) fizeram uso apenas oral uma única mulher fez uso apenas vaginal. Não há relação aparente entre dose, padrão de uso vaginal ou oral e internação hospitalar. ${ }^{75}$
\end{abstract}

Neste contexto de métodos, ainda existem as chamadas "casas das aborteiras", sendo estes, locais aonde são realizados abortos com o auxílio de mulheres mais experientes. ${ }^{76}$ Os métodos, nem um pouco ortodoxos, chegam a assustar, conforme descreve o relato,

74 DINIZ, Debora; MEDEIROS, Marcelo. Itinerários e métodos do aborto ilegal em cinco capitais brasileiras. Ciênc. saúde coletiva, Rio de Janeiro, v. 17, n. 7, p. 1671-1681, July 2012. Available from <http://www.scielo.br/scielo.php?script=sci_arttext\&pid=S1413-81232012000700002\&lng=en\&nr $\mathrm{m}=$ iso $>$. access on 12 Sept. 2016. p. 1678.

75 Ibidem. P. 1677.

76 Ibidem. 
As casas das aborteiras são também chamadas de 'clínicas de fundo de quintal' ou 'casas das curiosas', um espaço nebuloso em que práticas de alto risco são realizadas e repletas de segredo. Diferentemente das clínicas privadas, as casas das aborteiras estão escondidas nas periferias, em locais só conhecidos pela geografia da comunidade. A senhora aborteira é uma mulher idosa, descrita como uma 'enfermeira de hospital', o que sugere que ela tenha conhecimentos para além dos tradicionais. A típica casa da aborteira reserva um quarto para 0 atendimento das mulheres, cujos apetrechos são a sonda, o lubrificante e uma bacia. As mulheres descrevem os locais como sujos, escuros e sem proteção.

$[\ldots]$

A adolescente negra descreve o instrumento utilizado pela senhora aborteira como um 'ferro abortivo, um tipo de pegador de macarrão que ela colocou na minha vagina'. No conjunto das oitos mulheres que foram à casa da aborteira e combinaram a sonda com outros métodos, as experiências são muito diversas: há desde as que compraram a própria sonda e foram à casa da aborteira para que fosse introduzida na vagina para retirá-la no dia seguinte, antes de ir ao hospital, até aquela que permaneceu, em suas palavras, 'vários dias com a sonda, que foi colocada com arame cozido, umedecido com um óleo lubrificante para passagem na vagina'.

[...]

O retorno à casa não finaliza o ciclo do aborto. Há os cuidados pós-aborto. Mesmo para aquelas que iniciaram e finalizaram o aborto sem auxílio médico, os cuidados são instituídos e transmitidos pelas mulheres de sua rede de relações familiares ou afetivas. ${ }^{77}$

\section{O uso do Cytotec não difere muito no quesito consequências clínicas,}

As horas de espera pele efeito do cytotec são vividas diferentemente pelas mulheres. As adolescentes contam com a companhia das mães ou amigas, ao passo que as mulheres mais velhas e com maior nível educacional têm a presença dos companheiros. As narrativas de dor e sofrimento são compartilhadas por todas as mulheres, sendo particularmente marcante a expulsão do que elas chamam de 'bola', em geral no vaso sanitário. As que não suportam as dores, ou após muitas horas de sangramento sem expulsão, procuram os hospitais ao amanhecer. Elas suportam o tempo necessário para que o cytotec se dissolva no útero e não deixe rastros materiais do aborto ao olhar inquisitorial do médico: para algumas são necessárias quatro horas, para outras, seis horas de espera para que o citotec 'saia do sangue'. ${ }^{78}$

77 DINIZ, Debora; MEDEIROS, Marcelo. Itinerários e métodos do aborto ilegal em cinco capitais brasileiras. Ciênc. saúde coletiva, Rio de Janeiro, v. 17, n. 7, p. 1671-1681, July 2012 . Available from <http://www.scielo.br/scielo.php?script=sci_arttext\&pid=S1413-81232012000700002\&lng=en\&nr $\mathrm{m}=$ iso >. access on 12 Sept. 2016.. P. 1679.

78 Ibidem. p. 1678. 
O fato é que, $\mathrm{O}$ ato de praticar um aborto em si mesma transforma a mulher em uma portadora do conhecimento do aborto. Com isto o aborto se torna algo comum, dentro do contexto reprodutivo feminino. Este quadro, ligado a sua ilegalidade, métodos de alto risco e facilidade de acesso fazem do aborto um grave problema de saúde.

Segue abaixo, alguns relatos de procedimentos de aborto retirados da pesquisa de Heilborn at al, "Itinerários abortivos em contextos de clandestinidade na cidade do Rio de Janeiro":

Dayane (23 anos, CP, 2 filhos) fez quatro abortos com uma "curiosa". A primeira interrupção aos 20 anos, quando tinha uma filha pequena. Afirma que não tinha apoio para interromper a gravidez; já não morava mais com seus familiares e o parceiro era contra o aborto. No quarto mês de gravidez, ela conseguiu obter dele o dinheiro para interromper a gestação. Esta foi a primeira dentre as quatro vezes que recorreu à mesma "curiosa":

Ela bota um líquido na seringa e joga lá dentro. [...] Vai sangrando, você começa a sentir dor e é como se fosse um parto. É horrível a sensação. [...] Demorou umas dez horas. Eu cheguei lá era uma hora da tarde e no dia seguinte, quando foi nove da manhã eu já tinha expelido a criança. [...] Depois de vinte e quatro horas que eu fui para o hospital fazer a curetagem, porque ficam restos dentro e tem que limpar.

Dayane usou diversas vezes a pílula do dia seguinte, até quando profissionais do posto de saúde que frequentava recusaram-se a entregar o medicamento. Em todas as interrupções de gestação, ela precisou ser levada para o hospital por complicações pós-aborto. Na última vez, "quase morreu". Apesar das advertências da "curiosa", o procedimento foi realizado em estágio avançado de gestação, pois "estava desesperada".

Bruna (22 anos, CP, 3 abortos, 2 filhos) fez dois abortos com "curiosas" e em ambas as situações houve complicações. Aos 20 anos, com uma filha pequena e face a uma gestação resultante de um parceiro eventual, ela não hesita em interrompê-la. Primeiramente, tenta o chá de "buchinha do norte", indicado por uma amiga. Como não surtiu efeito, informa à mãe estar grávida, a qual providencia o dinheiro $(R \$ 70,00)$ para o aborto. A entrevistada retorna à casa da "curiosa" para aplicar o "remédio novamente":

Aí, eu consegui, caiu o nenê em casa, fui para o hospital, porque estava sentindo muita dor, estava perdendo muito sangue. Ele caiu dentro do vaso [...] Era uma bolinha de sangue pequenininha, não deu nem para ver, só sabia por que tinha sangue saindo. [...] Fiquei internada uma semana, não falei que tinha feito aborto. Falei que eu tinha caído (...) fiquei no soro, depois fiz a curetagem. Três dias com hemorragia, fiz outra curetagem, depois me deram alta.

Situação dramática é vivida por Thainá (24 anos, CP, 2 filhos - uma tentativa de aborto e 1 aborto). Ela tem apenas o fundamental incompleto; trabalha em barracas de festas de rua preparando alimentos e em "biscates quando aparece". Diz que ela e seu parceiro não queriam a segunda gestação, pois o primeiro filho era recente. Na tentativa de aborto, primeiramente ela toma o Misoprostol; sem sucesso, procurou uma "curiosa". A sonda utilizada perfurou os rins e o intestino. $O$ feto sobreviveu sem sequelas. Thainá ficou em coma por três dias e afirma que "quase morreu". Vivendo em um relacionamento violento, ela se separa do parceiro. Aos 21 anos, engravida de novo, em uma relação sexual ocasional. Mais uma vez, faz uso de diversos procedimentos 
para interromper a gestação: chás de "buchinha do norte", de maconha, de cachaça com arruda, de cogumelo fervido com vinho, de folha de café; Misoprostol, mas nada funcionou. Foi então que recorreu a outra "curiosa", que utilizou um líquido e talo de mamona. Vinte e quatro horas depois de ter feito o procedimento, passando muito mal, com cólica e febre, resolveu ir para o hospital:

umas duas a três horas do negócio já em mim, eu já comecei a sentir cólica... sangrando, aí começou a me dar febre. Fui parar no hospital [...] Me deu a convulsão, até então eu tava naquela que o feto ia descer... $E$ o feto já estava morto dentro de mim e eu não sabia. Devido a ele já estava morto, a dor veio, mas eu num..., ele tava agarrado na placenta. O caso ilustra como a relação das mulheres com os serviços de saúde, em situações de aborto, pode ser complicada. Levada para o hospital público, que se recusa a recebê-la, seu pai aciona a polícia para a filha ser atendida. Em absoluto contraste com os casos de aborto descritos estão os realizados por moças de camadas médias. Os percursos são mais lineares: passa-se rápido da descoberta da gravidez à certeza da interrupção, não havendo em suas trajetórias espaço para hesitação18. Não há ingestão de chás ou Misoprostol; as clínicas médicas privadas são as eleitas. Não há qualquer relato de complicação pós-aborto, o que faz supor que sejam clínicas de 'bom padrão', com procedimentos mais seguros e assépticos, ainda que clandestinas. O depoimento de Regiane (24 anos, CM, um aborto aos 19) ilustra tal distinção:

Eles fizeram uma coisa muito bem feita. Eu contei para o meu ginecologista, eu fiz vários exames e não tive problema algum. Você fica limpinha. Quando eu cheguei lá eles me trataram bem, eu chorava muito, falavam que seu eu não quisesse fazer, que eles não fariam. Eles me deixaram muito à vontade. Eu falei que queria fazer. Mesmo sofrendo e chorando, a minha barriga estava crescendo já.

Outro elemento comum às narrativas de $\mathrm{CM}$ é o apoio dos pais. Quase sempre eles são os primeiros a saberem da gravidez da filha, sobretudo a mãe, e em geral pagam pelo procedimento. Apesar da decepção ou 'chateação', os pais se mostram favoráveis à decisão da filha. Em somente um caso, a família da moça não esteve a par da gestação. O aborto é realizado com apoio do parceiro e dos pais dele. ${ }^{79}$

\section{É notável, com base nos relatos, as dificuldades, condições, violência e}

riscos que estas mulheres são expostas. A ilegalidade do aborto o leva a clandestinidade e práticas consideradas desumanas. Sua ilegalidade afeta - inclusive - a realização de procedimentos legais.

No hospital $\mathrm{P}, 89$ mulheres vítimas de estupros, grávidas, pediram para interromper a gravidez entre 2002 e 2008, mas só 49 conseguiram um aborto legal (dados fornecidos à pesquisadora pela diretoria do Hospital $\mathrm{P}$ em outubro de 2009). Em muitos casos, quando as mulheres solicitavam o aborto

79 HEILBORN, Maria Luiza et al . Itinerários abortivos em contextos de clandestinidade na cidade do Rio de Janeiro - Brasil. Ciênc. saúde coletiva, Rio de Janeiro , v. 17, n. 7, p. 1699-1708, July 2012 Available from <http://www.scielo.br/scielo.php?script=sci_arttext\&pid=S1413$81232012000700008 \& \ln \mathrm{g}=e n \& n r m=i s 0>$. access on 12 Sept. 2016. P. 1704. Grifos do autor. 
ou quando o comitê de ética do hospital aprovava o pedido delas, o prazo legal para o abortamento já tinha decorrido. ${ }^{80}$

Dentre estas circunstancias, ficam evidentes as dimensões do problema chamado aborto. Sua condição de ilegalidade atua sobre a vida de milhares de mulheres todos os anos e seu debate, longo e exaustivo, parece estar longe de um final.

80 DE ZORDO, Silvia. Representações e experiências sobre aborto legal e ilegal dos ginecologistas-obstetras trabalhando em dois hospitais maternidade de Salvador da Bahia. Ciênc. saúde coletiva, Rio de Janeiro, v. 17, n. 7, p. 1745-1754, July 2012 . Available from $<$ http://www.scielo.br/scielo.php?script=sci_arttext\&pid=S1413-81232012000700013\&lng=en\&nrm=iso $>$ access on 12 Sept. 2016. 


\section{CAPÍTULO III}

\section{METODOLOGIA E RESULTADOS DA PESQUISA}

\subsection{METODOLOGIA DA PESQUISA}

Para o desenvolvimento desta pesquisa foi utilizada a seguinte metodologia: Primeiramente foi realizado um estudo bibliográfico, qualitativo, de natureza analítica, aplica e indutiva, no que tange ao Biopoder e sua atuação nos parlamentos Brasileiro e Uruguaio, assim como, a análise do procedimento legislativo em ambos os parlamentos.

Identificou-se os grupos de interesse nas políticas públicas, verificando como se agrupam e como se relacionam entre si, e como influenciam em decisões.

Foi realizada uma pesquisa de campo, com um questionário, dentro da Câmara dos Deputados no Brasil (população), com o objetivo de identificar fatores relativos ao tema Biopoder, verificando assim o nível de conservantismo.

Este Questionário não foi aplicado no Congresso uruguaio, sendo os dados referente ao mesmo obtidos através de pesquisa bibliográfica em fonte primária, representados pelas atas da votação da lei do aborto no Uruguai (especificamente o diário de sessão número 3.813 da Câmara de Representantes do parlamento uruguaio), disponíveis no site daquele parlamento.

Neste questionário, aplicado no período de março a abril de 2017, os entrevistados responderam a 18 questões, aonde afirmaram se discordam plenamente, discordam, sem opinião, concordam ou concordam plenamente. As respostas geraram dados, com os quais, fora possível estabelecer o índice.

O Questionário foi aplicado especificamente (Amostra) aos membros da Comissão de Seguridade Social e Família - CSSF e da Comissão de Constituição e Justiça e de Cidadania - CCJC, órgãos responsáveis pelo andamento dos projetos de leis referentes ao aborto de maior relevância. 


\subsection{PESQUISA BRASIL}

Neste subcapítulo serão apresentados os dados obtidos na pesquisa de campo realizada no Congresso Nacional brasileiro, mais especificamente, nas Comissões de Constituição, Justiça e de Cidadania (C.C.J.C.) e de Seguridade Social e Família (C.S.S.F.) da Câmara dos Deputados do Brasil.

A escolha do grupo se deu no decorrer da pesquisa bibliográfica onde foi verificado a concentração de projetos relativos ao tema nestas duas comissões. Como o primeiro passo para a aprovação de uma lei é sua aprovação em uma das comissões, decidiu-se aplicar o questionário na C.C.J.C. e na C.S.S.F. buscando analisar as possibilidades relativas aos projetos analisados por elas.

A pesquisa foi apresentada aos parlamentares na forma de um questionário (vide anexo IV) composto por 18 questões referentes ao aborto, fundamentos das escolhas de respostas e Direitos Sexuais e Reprodutivos. As respostas possíveis no questionário eram Concordo Plenamente (C.P.), Concordo (C.), Concordo em Parte (C.E.P.), Discordo (D.) e Discordo Plenamente (D.P.). Para a melhor analise do poder de decisão dos parlamentares considerou-se as seguintes respostar: Concorda (C.P. + C.), Concordo em Parte e Discordo (D. + D.P.). Aqueles que aceitaram participar da pesquisa assinaram o Termo de Consentimento Livre e Esclarecido - T.C.L.E. (Anexo III). 
Gráfico 01 - População: Pesquisa Brasil

\section{População da Pesquisa}

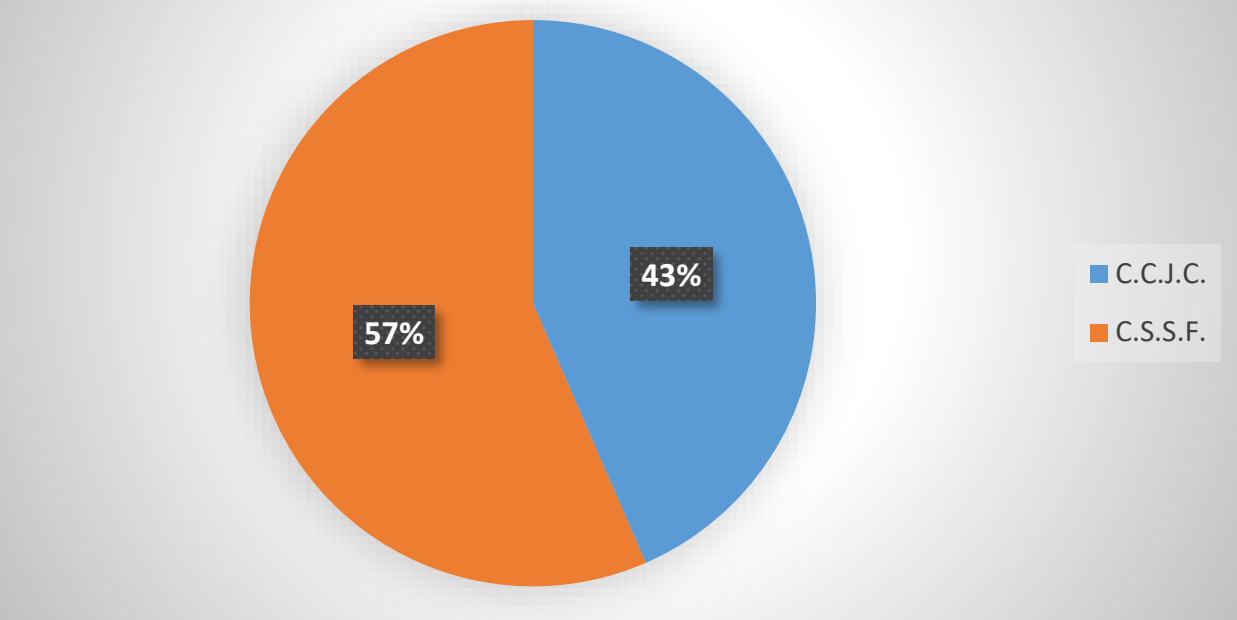

Fonte: Elaborado pelo autor. 2017.

A população analisada na pesquisa era composta por 115 (cento e quinze) deputados, sendo, 65 da C.S.S.F. e 50 da C.C.J.C, representando, conforme o gráfico abaixo, $57 \%$ membros da C.S.S.F. e $43 \%$ da C.C.J.C.

Apresentada a pesquisa aos parlamentares, do total de parlamentares que compõem a população analisada, $72 \%$ deste percentual aceitaram analisar o questionário ${ }^{81}$ para decidir se participariam. $28 \%$ descartaram a possibilidade de responderem ao questionário sem análise prévia. Conforme o gráfico abaixo.

81 Vide anexo. 


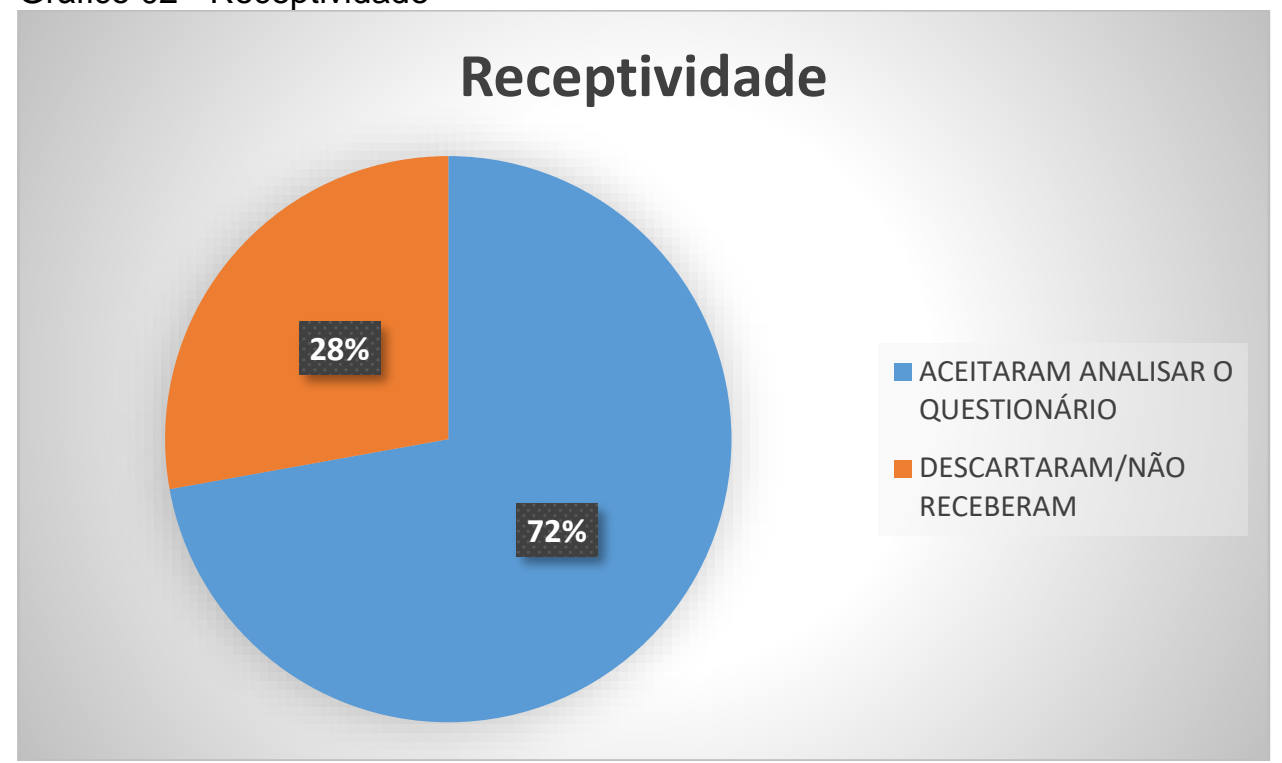

Fonte: Elaborado pelo autor. 2017.

Analisando o gráfico 2 podemos verificar que dos $72 \%$ parlamentares que aceitaram analisar os questionários, 83 deputados, apenas $12 \%$ devolveram os questionários respondidos.

Declarando falta de interesse em participar de pesquisas universitárias $2,4 \%$ dos deputados devolveram o questionário em branco. Alegando falta de tempo e/ou disposição para responder as perguntas, 36,1\% e 49,4\% dos parlamentares devolveram os questionários, não aceitando participar da pesquisa devido a polêmica de seu conteúdo, preferindo assim, mesmo com o caráter sigiloso da pesquisa, não emitir opinião relativa ao tema. 
Gráfico 03 - Resposta à Pesquisa

\section{Resposta à Pesquisa}

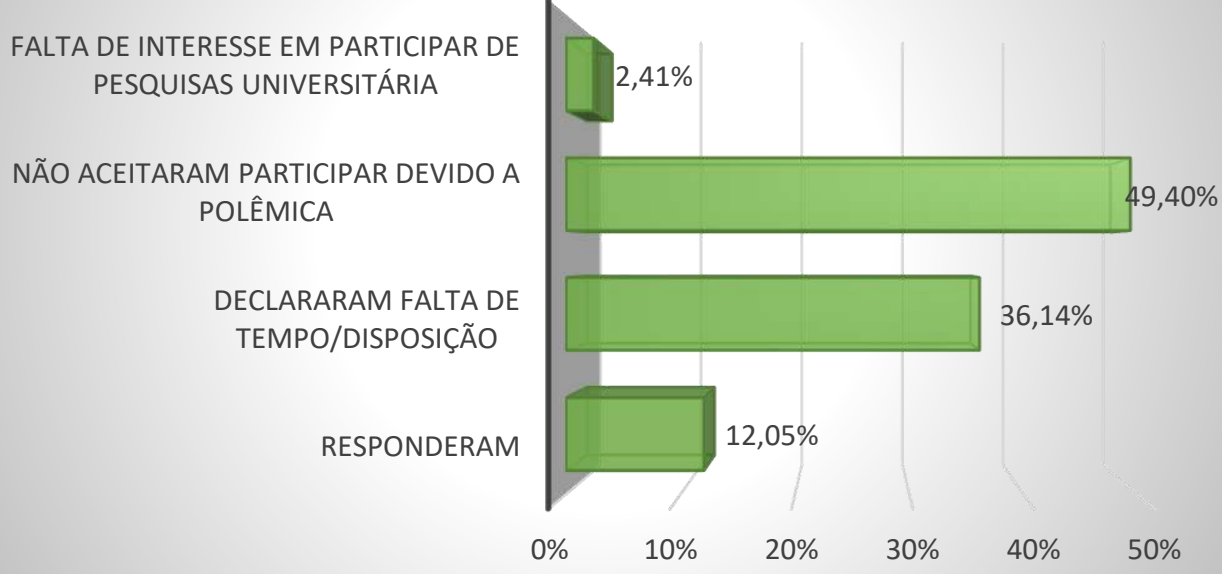

Fonte: Elaborado pelo autor. 2017.

Do total de parlamentares que não aceitaram participar da pesquisa alegando ser está muito polêmica, ao serem questionados pelo pesquisador a respeito da justificativa $14,6 \%$ se negaram a justificar. $22 \%$ pautaram em questões sociais e 63,4\% em motivos religiosos (Gráfico 04).

Gráfico 04 - Não Aceitaram Participar Devido a Polêmica

NÃO ACEITARAM PARTICIPAR DEVIDO A POLÊMICA

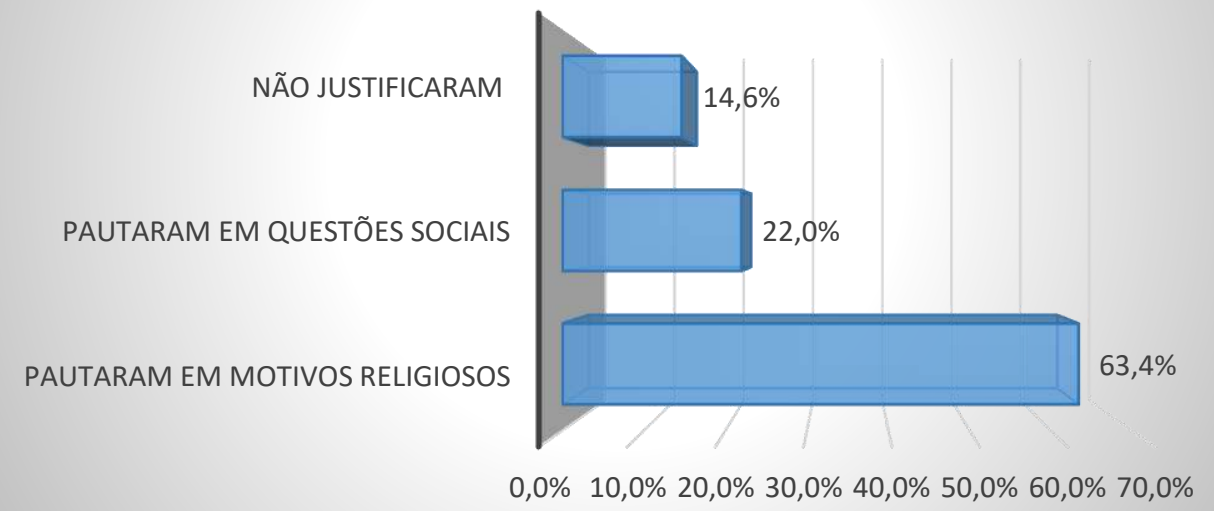

Fonte: Elaborado pelo autor. 2017. 
Este fato levou à uma análise a respeito da composição das comissões pesquisadas (Gráfico 05) que revelou que 61,7\% dos parlamentares participavam de alguma Frente Parlamentar de cunho religioso. 40\% eram membros da Frente Parlamentar Evangélica do Congresso Nacional ${ }^{82}$, 35,7\% membros da Frente Parlamentar Mista Católica Apostólica Romana ${ }^{83}$. Alguns parlamentares participavam de ambas as frentes representando 13,9\%. Do total de deputados da C.C.J.C, 88\% participavam de uma das frentes parlamentares acima citadas assim como, 41,5\% dos membros da C.S.S.F..

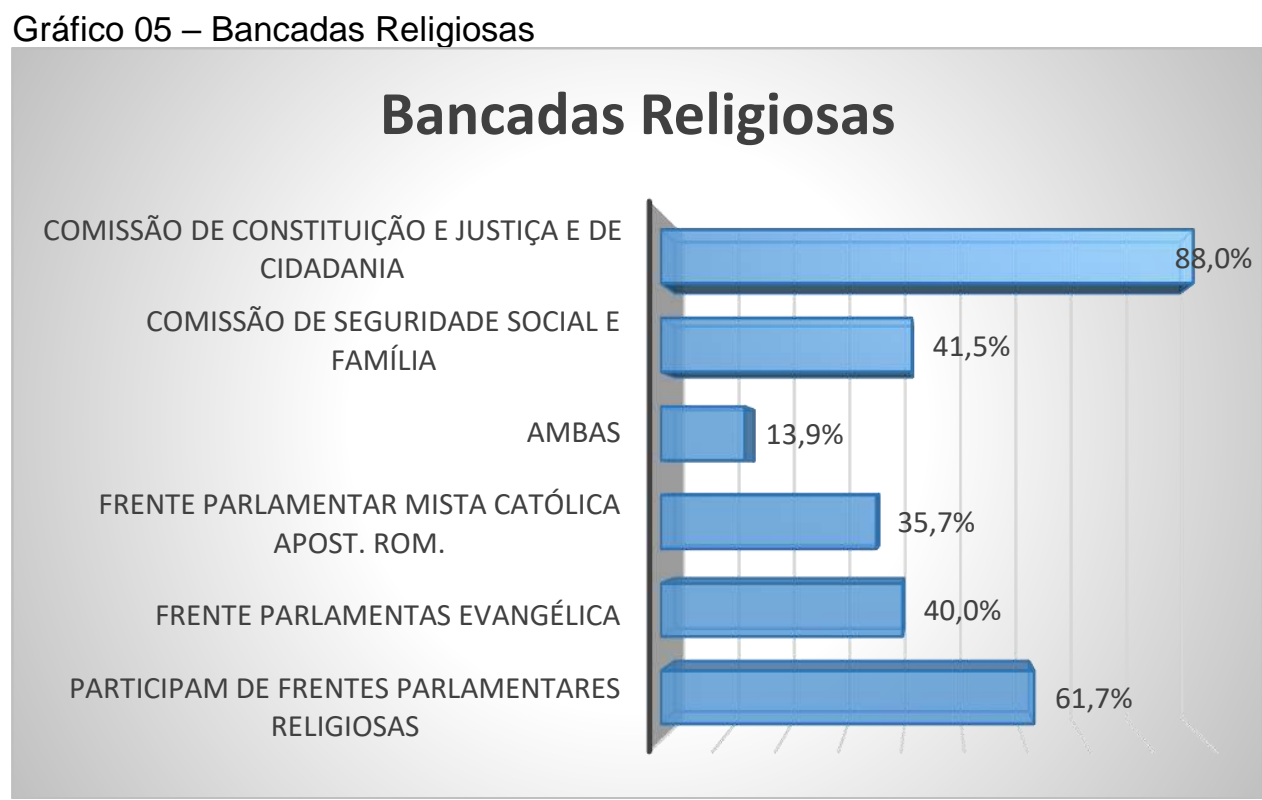

Fonte: Elaborado pelo autor. 2017.

Analisando os itens do questionário, separando e agrupando as perguntas por áreas de interesse, foram identificados os seguintes valores em relação aos Direitos Sexuais e Reprodutivos.

82 A Frente Parlamentar Evangélica do Congresso Nacional foi criada em 2015 e conta hoje com 198 deputados e 4 senadores. Para maiores informações consultar: $<$ http://www.camara.leg.br/internet/deputado/frenteDetalhe.asp?id=53658> Acessado em 30 de Julho de 2017.

83 A frente Parlamentar Mista Católica Apostólica Romana foi criada em 2015 e conta hoje com215 Deputados e 5 Senadores. Para maiores informações consultar: < http://www.camara.leg.br/internet/deputado/frenteDetalhe.asp?id=53496> Acessado em 30 de julho de 2017. 
Gráfico 06 - Direitos Sexuais e Reprodutivos

\section{DIREITOS SEXUAIS E REPRODUTIVOS}

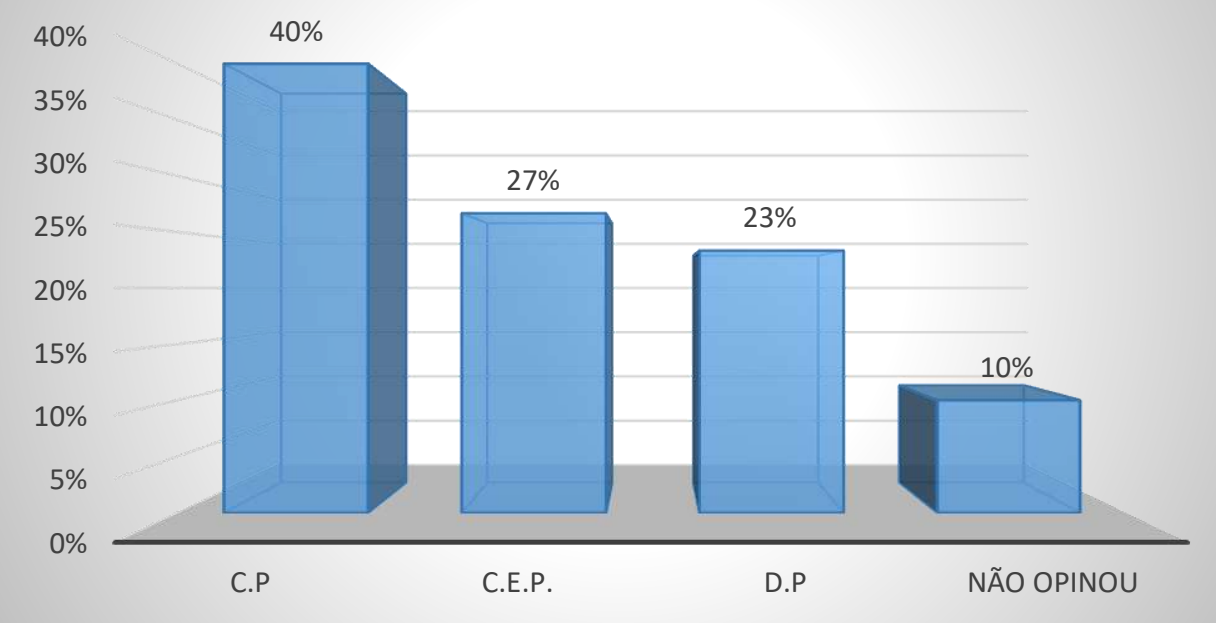

Fonte: Elaborado pelo autor. 2017.

Conforme o gráfico apresenta, $40 \%$ dos parlamentares que responderam ao questionário Concordam Plenamente com a inserção dos Direitos Sexuais e Reprodutivos, $27 \%$ concordam em parte e $23 \%$ discordam plenamente da existência destes direitos. $10 \%$ preferiram não responder as questões relacionadas ao tema.

Perguntados a respeito da atuação do Estado nas questões de Biopoder, e se este, realmente, teria o direito de agir e legislar sobre a vida, $48 \%$ concordaram plenamente com está afirmação, conforme é possível analisar no gráfico abaixo.

Gráfico 07 - Pertence ao Estado o Biopoder

\section{PERTENCE AO ESTADO O BIOPODER}

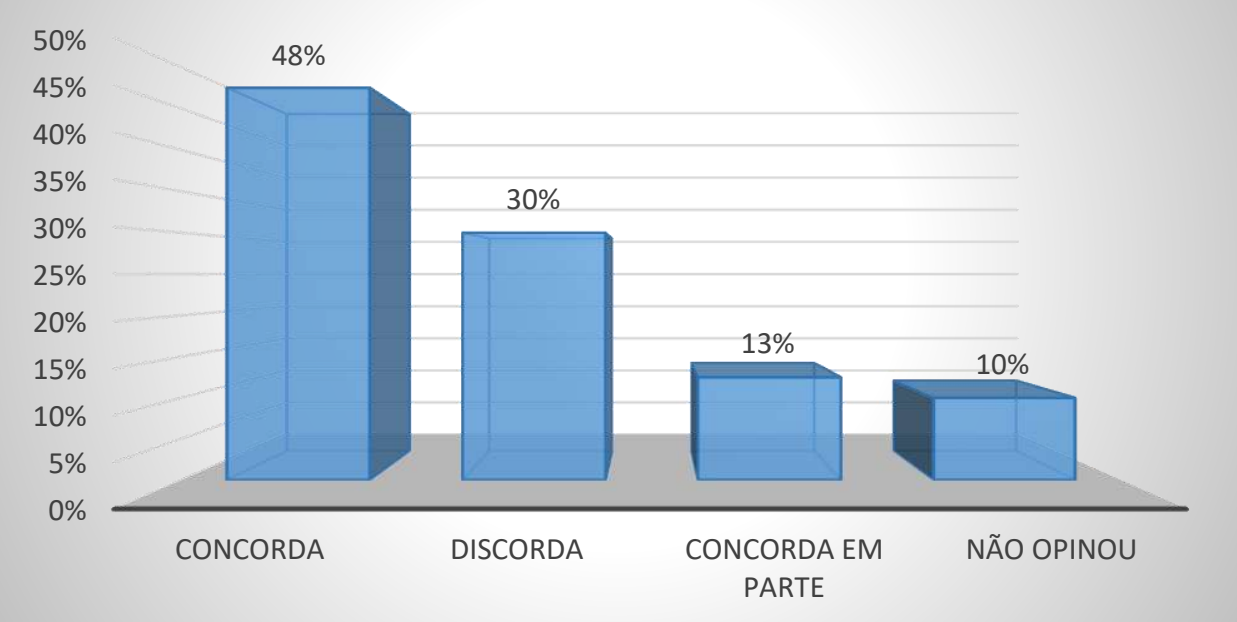

Fonte: Elaborado pelo autor. 2017. 
$30 \%$ discordaram desta afirmação, $13 \%$ dos entrevistados concordam em parte com isto e $10 \%$ acharam por bem, não responderem as questões relativas a temática.

Questionados a respeito do aborto como crime, grande maioria respondeu afirmativamente à questão. $70 \%$ dos entrevistados consideram o aborto como crime, $20 \%$ discordam desta afirmação e $10 \%$ concordam em parte, conforme revela o gráfico na próxima página

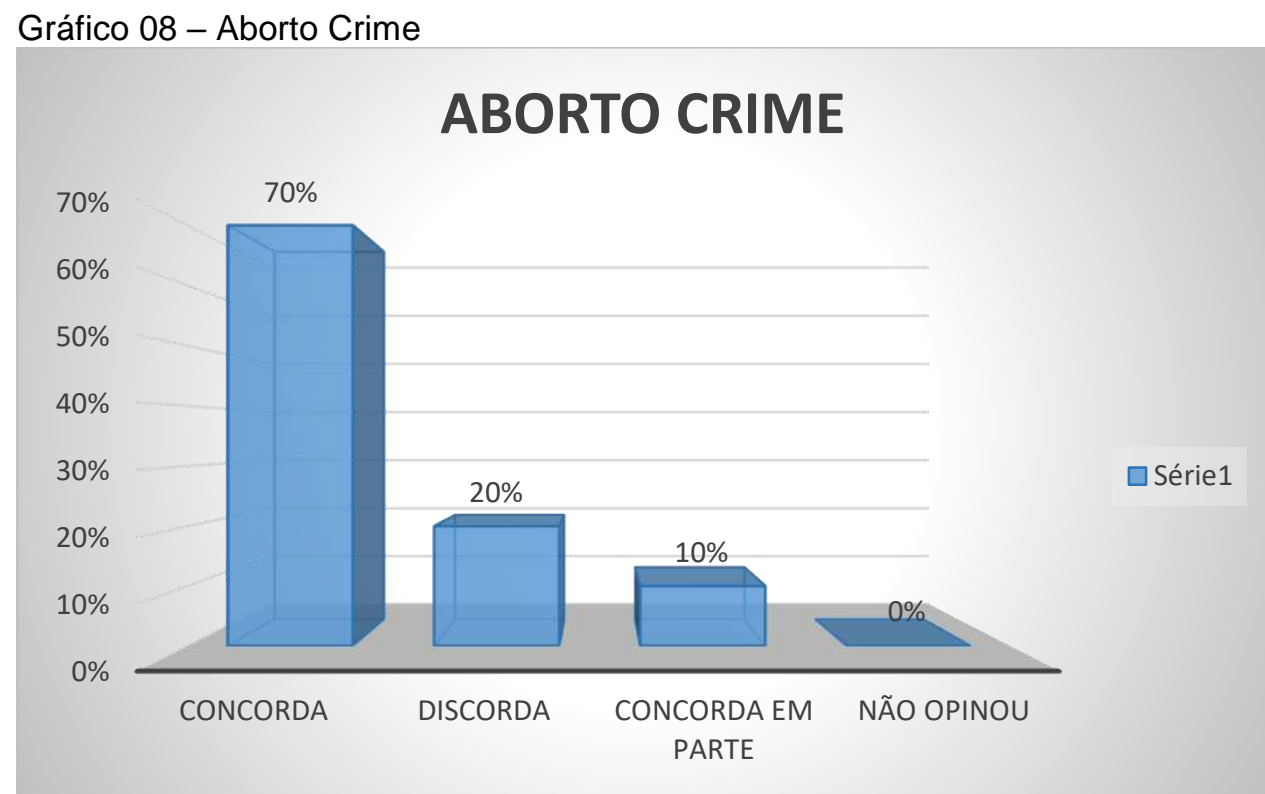

Fonte: Elaborado pelo autor. 2017.

Quando questionados a respeito da possibilidade de aborto em casos de estupro revelou-se que $40 \%$ dos pesquisados discordam plenamente desta prática. Verificar gráfico abaixo. 
Gráfico 09 - Aborto em Caso de Estupro

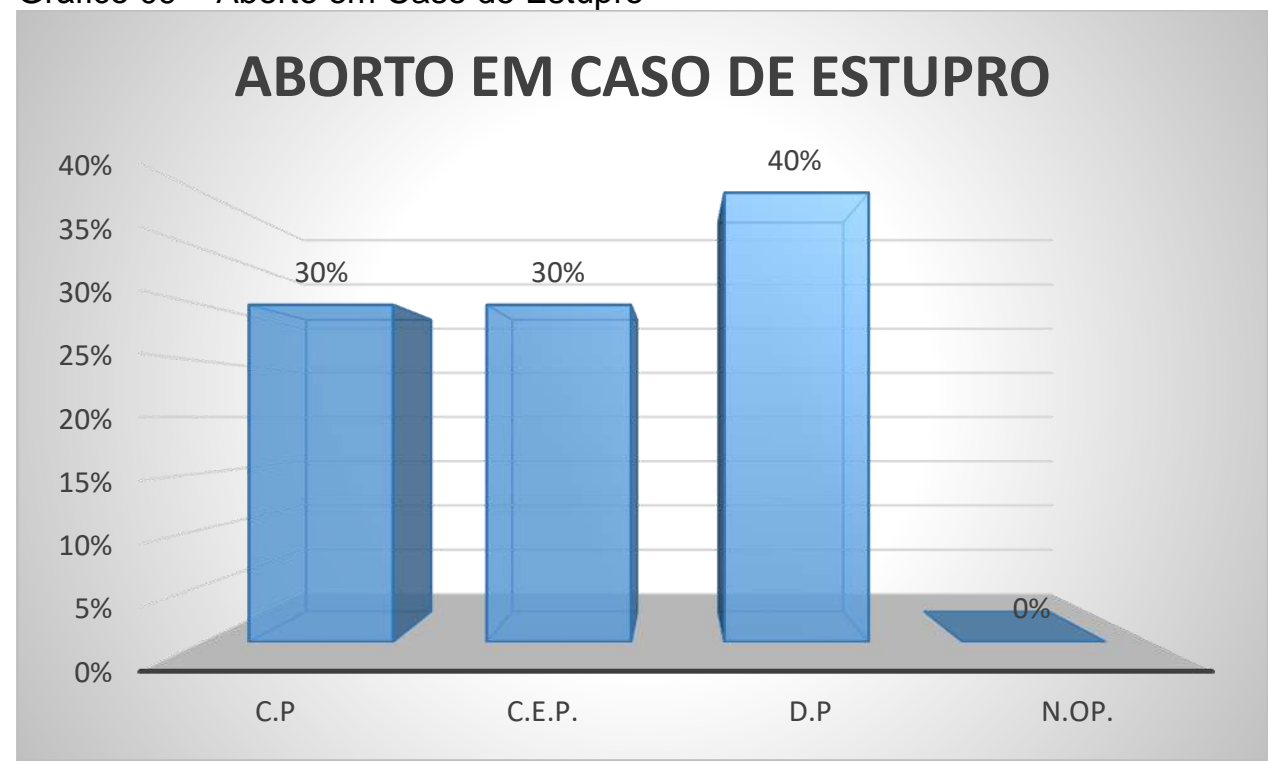

Fonte: Elaborado pelo autor. 2017.

Apenas $30 \%$ dos entrevistados consideram plenamente a possibilidade de aborto em casos de estupro. O restante, $30 \%$, concordam em parte com está medida. A respeito do aborto de feto anencefálico a situação modifica significativamente, fato que pode ser analisado no gráfico abaixo.

Gráfico 10 - Aborto Feto Anencefálico

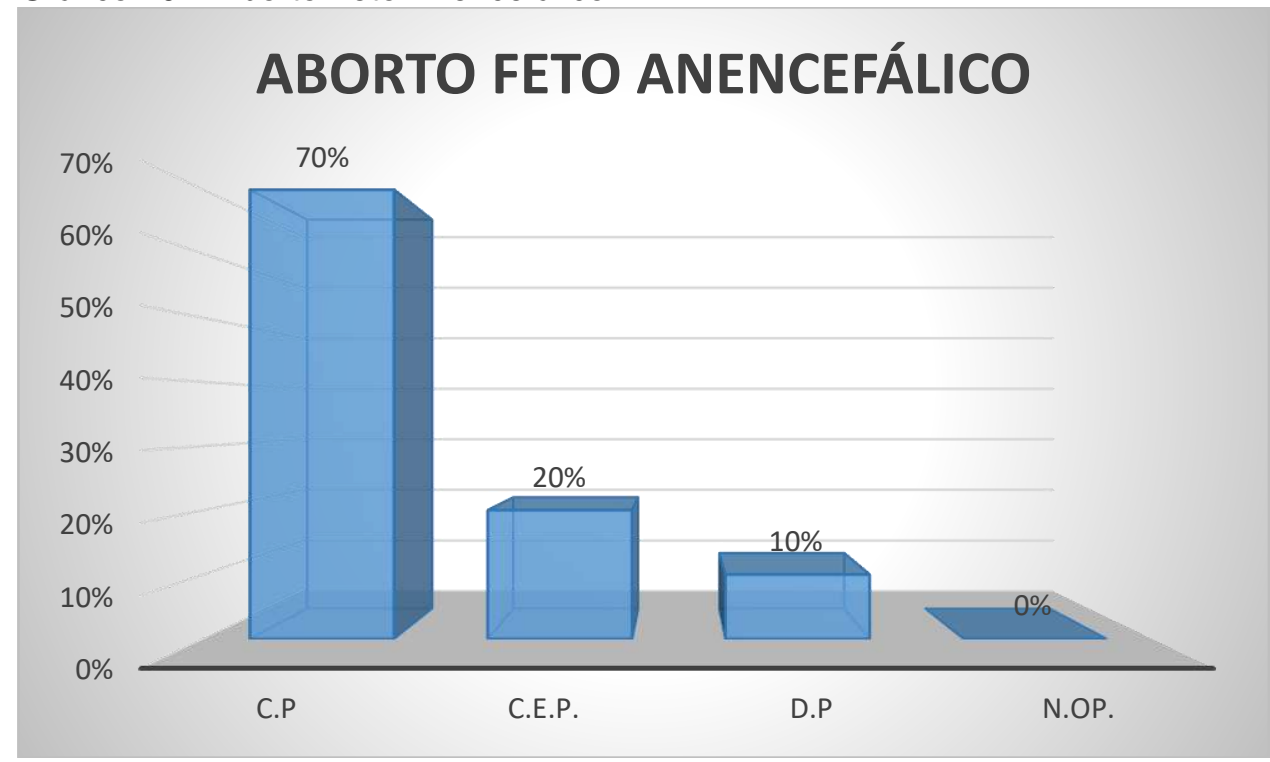

Fonte: Elaborado pelo autor. 2017. 
Conforme mostra o gráfico 10 apenas $10 \%$ dos entrevistados discordam da prática do aborto em casos de anencefalia. $20 \%$ consideram em parte esta possibilidade e a grande maioria, $70 \%$, concordam plenamente com a prática do aborto nesta situação. Com relação ao aborto no caso de risco a gestante, revelou-se o seguinte gráfico.

Em termos gerais o aborto é considerado por ampla maioria. $20 \%$ dos entrevistados consideram, em parte, o aborto em situações de risco a vida da gestante e $80 \%$ concordo plenamente com a realização da prática. Conforme mostra o gráfico 9 (Próxima Página).

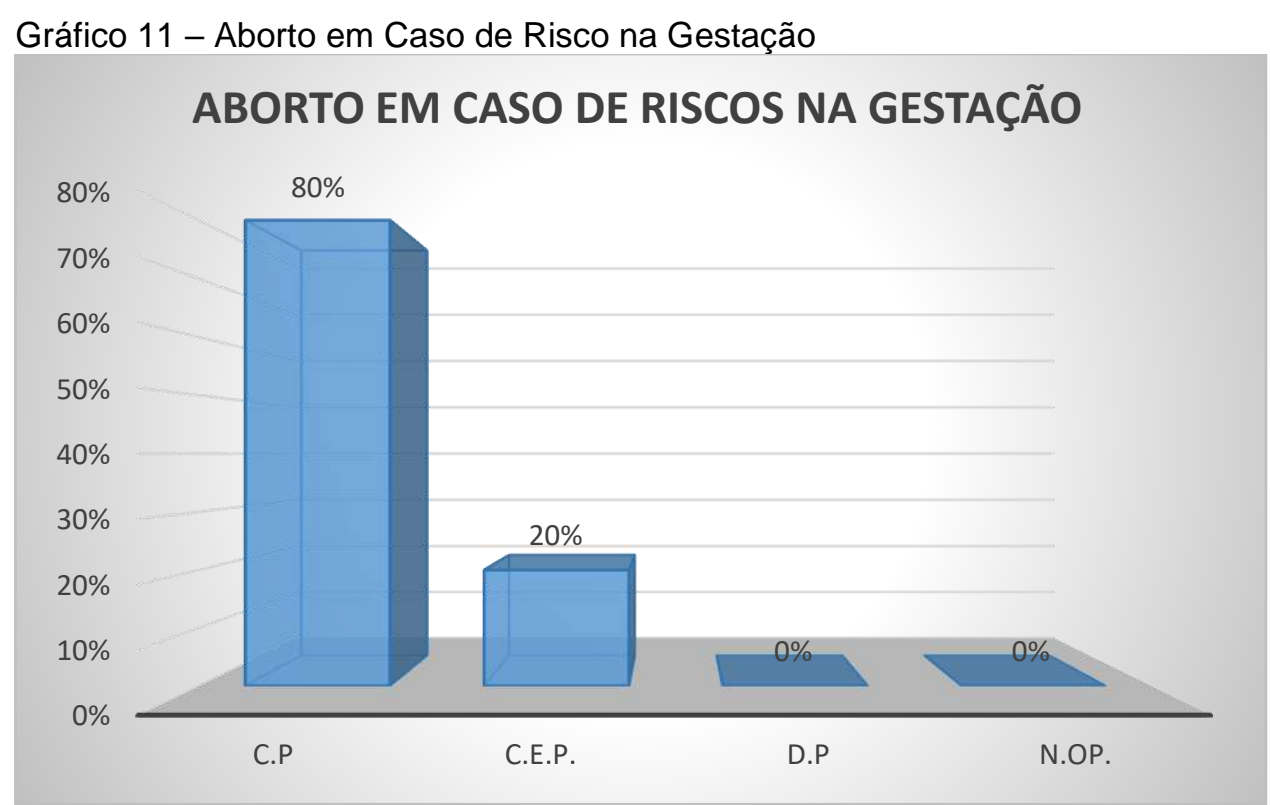

Fonte: Elaborado pelo autor. 2017.

Quando perguntados a respeito da prática do aborto até o período biológico indicado (12 semanas) apenas $30 \%$ se declararam a favor, concordando plenamente com a realização. $70 \%$ declaram-se contra a realização do aborto nestes termos. Ver gráfico 12. 
Gráfico 12 - Aborto Permitido (12 Semanas)

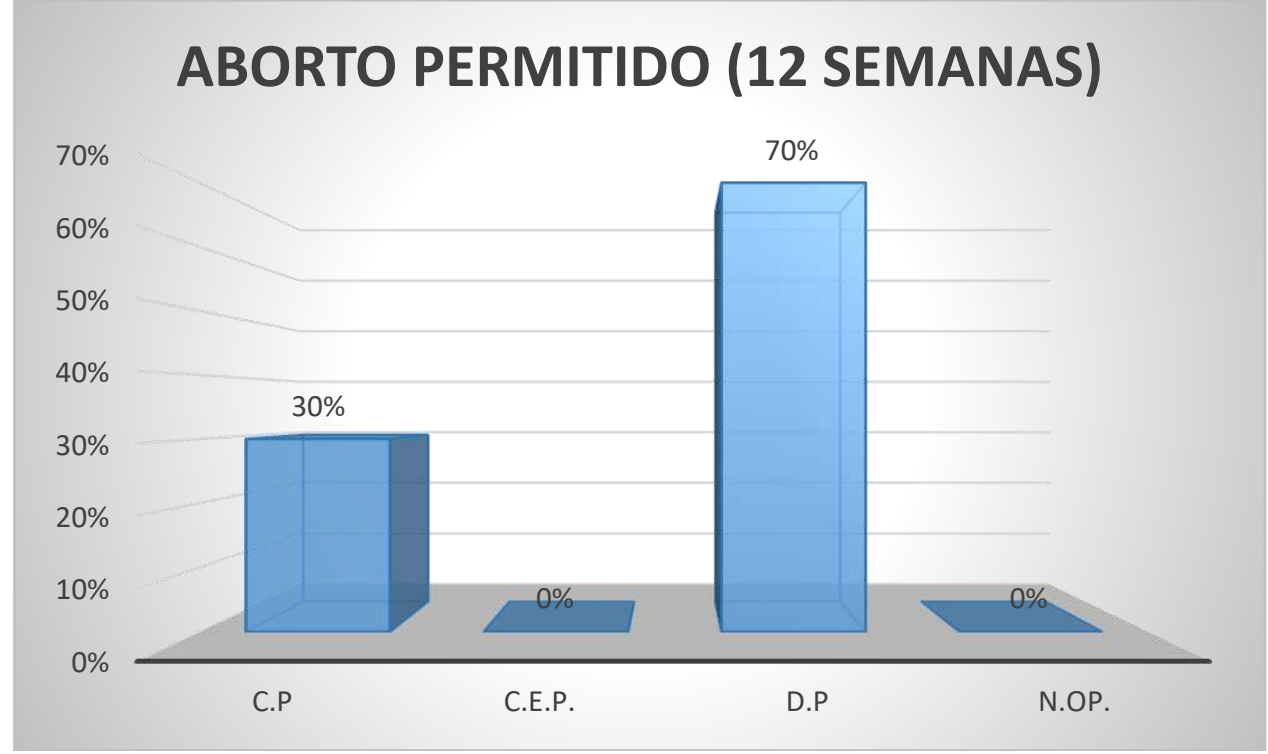

Fonte: Elaborado pelo autor. 2017.

A respeito de considerarem o aborto como algo benéfico à sociedade $60 \%$ concordaram com esta afirmação, ver gráfico abaixo, e $40 \%$ discordaram alegando que possibilidade de este gerar riscos a sociedade.

Gráfico 13 - Aborto Positivo a Sociedade

\section{ABORTO POSITIVO A SOCIEDADE}

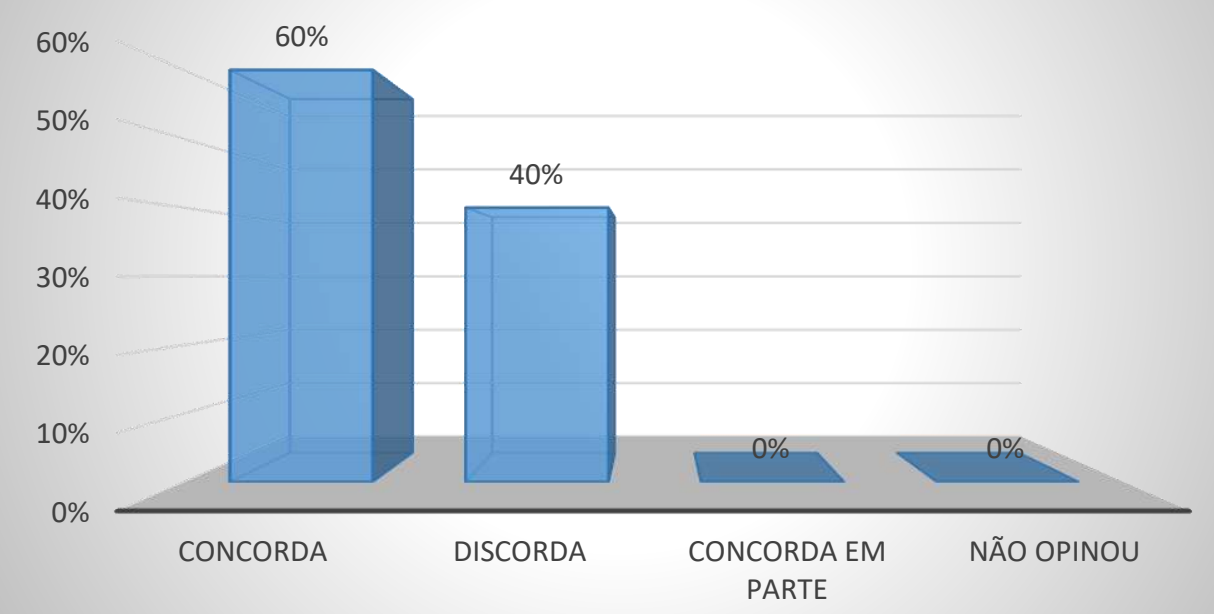

Fonte: Elaborado pelo autor. 2017. 
Quando questionados se suas respostas e princípios eram baseados, também, em conceitos religiosos, 40\% discordaram plenamente desta afirmativa, conforme pode ser verificado no gráfico 12 (próxima página).

$30 \%$ responderam que concordavam parcialmente e o restante, $30 \%$, concordavam plenamente que suas respostas eram baseadas em conceitos religiosos.

Gráfico 14 - Conceitos Religiosos

\section{CONCEITOS RELIGIOSOS}

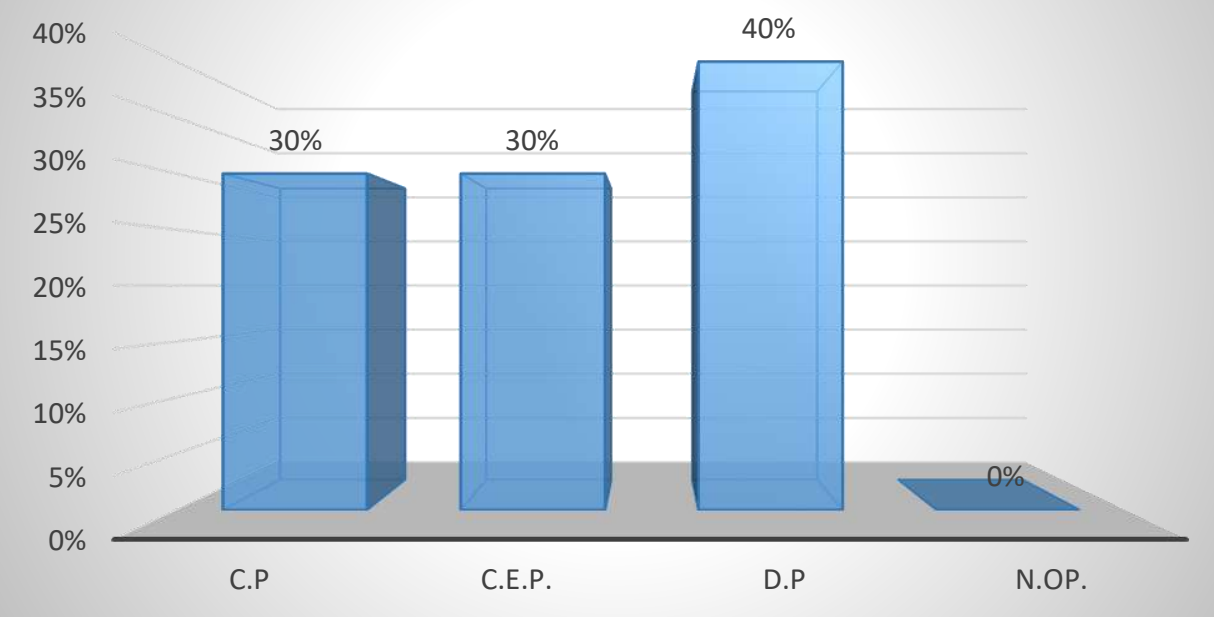

Fonte: Elaborado pelo autor. 2017.

Conforme pode ser analisado no próximo gráfico, 40\% declaram que suas respostas eram também formuladas com base em conceitos científicos. $50 \%$ declararam que concordavam em parte com está afirmação e 10\% discordaram plenamente. 
Gráfico 15 - Conceitos Científicos

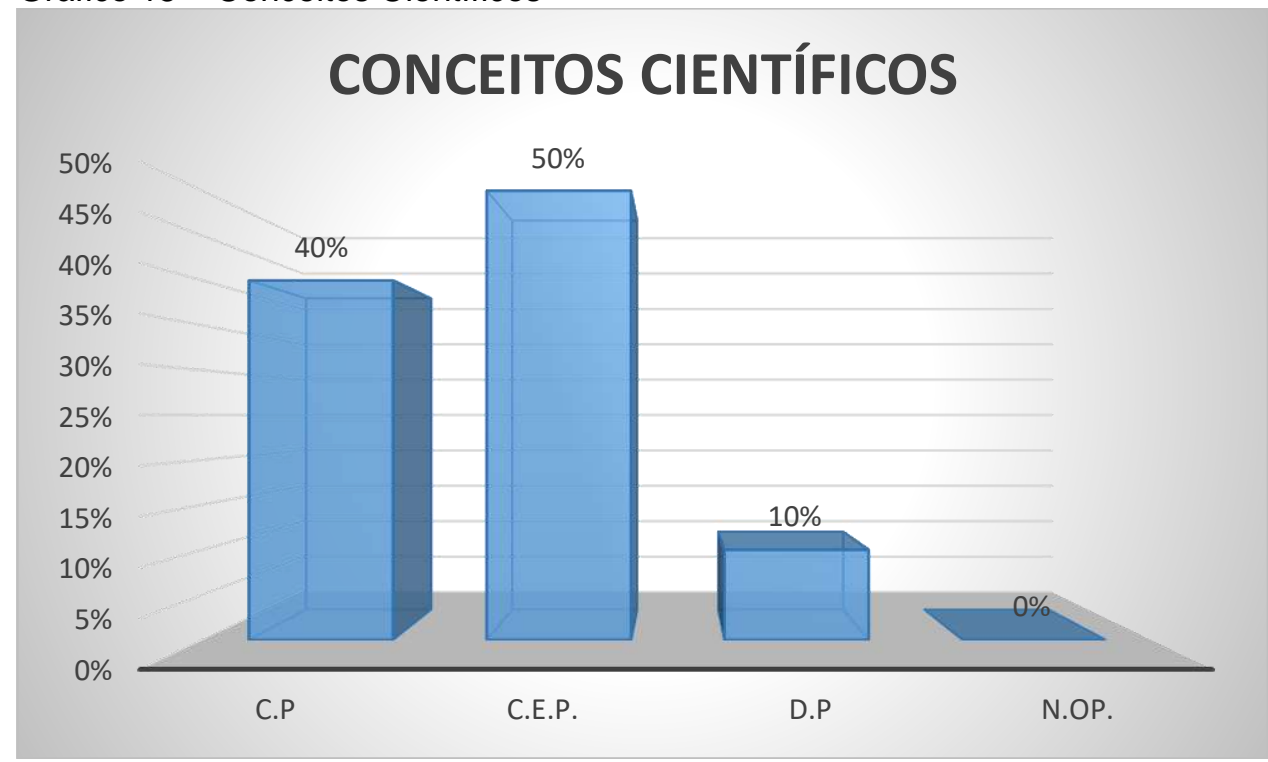

Fonte: Elaborado pelo autor. 2017.

Questionados novamente a respeito de suas bases de conceitos, desta vez tendo como referência conceitos éticos e morais, manteve-se o padrão encontrado em relação aos conceitos científicos. $40 \%$ concordaram plenamente com a afirmativa, $50 \%$ concordaram em parte e, apenas, $10 \%$ discordaram plenamente. Vide gráfico abaixo.

Gráfico 16 - Conceitos Éticos e Morais

\section{CONCEITOS ÉTICOS E MORAIS}

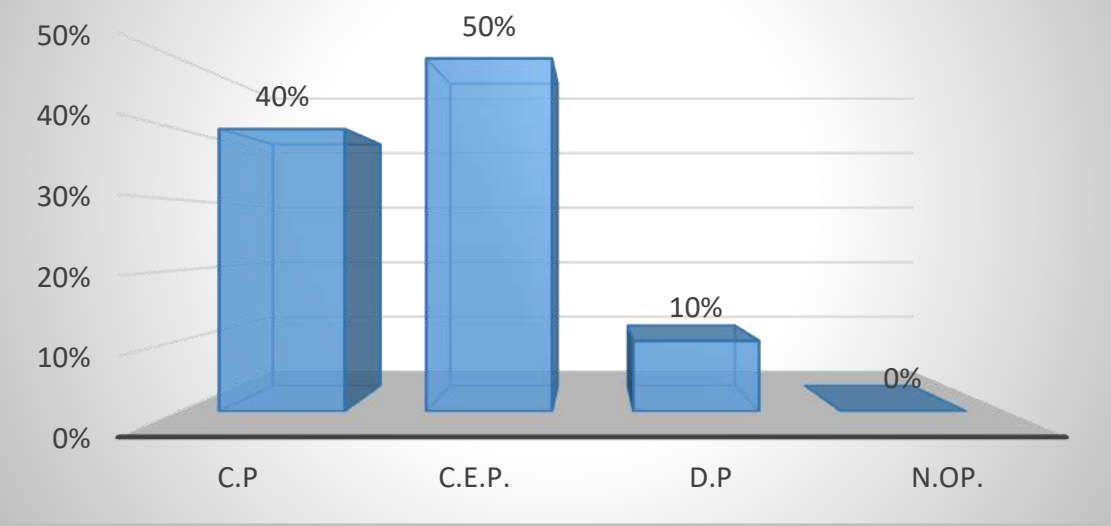

Fonte: Elaborado pelo autor 2017. 
Na soma geral dos dados obtidos na pesquisa obtêm-se a seguinte representação gráfica.

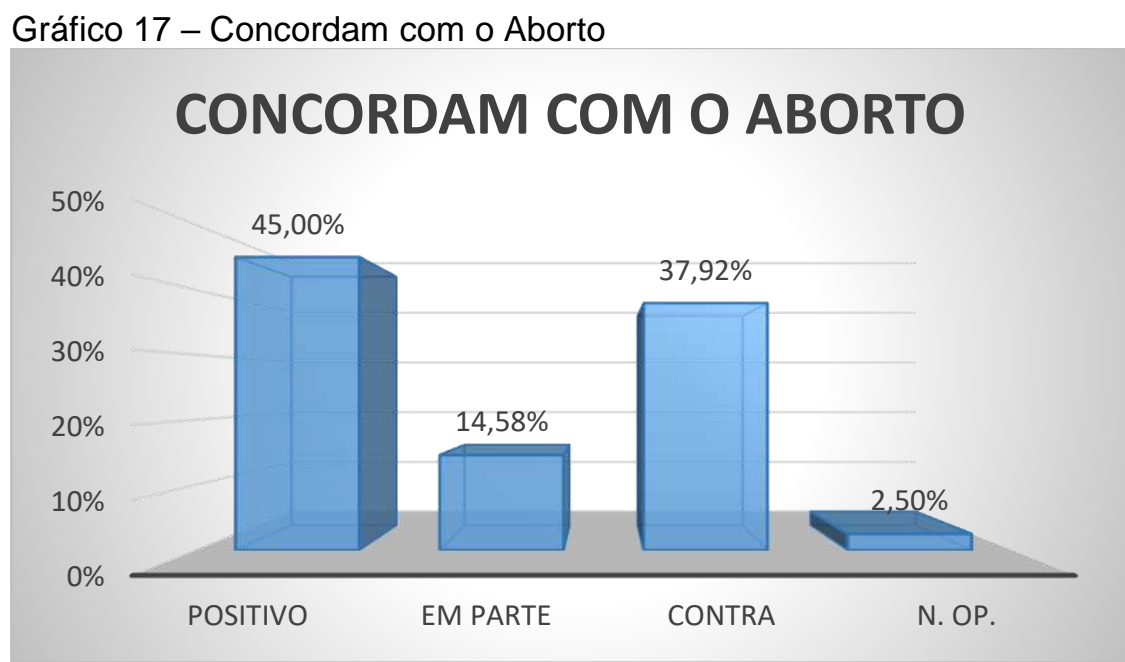

Fonte: Elaborado pelo autor. 2017.

Somando-se todos os aspectos questionados é possível verificar que $45 \%$ dos entrevistados concordam com a regulamentação do aborto. 15,58\% declaram que concordam em parte e 37,92\% são abertamente contra. 2,5\% acharam por bem não emitir opinião a respeito.

Dos parlamentares que se dispuseram a responder o questionário $80 \%$, conforme gráfico abaixo, eram do sexo masculino, $10 \%$ se declaram do sexo feminino e $10 \%$ não declararam sexo. 
Gráfico 18 - Sexo

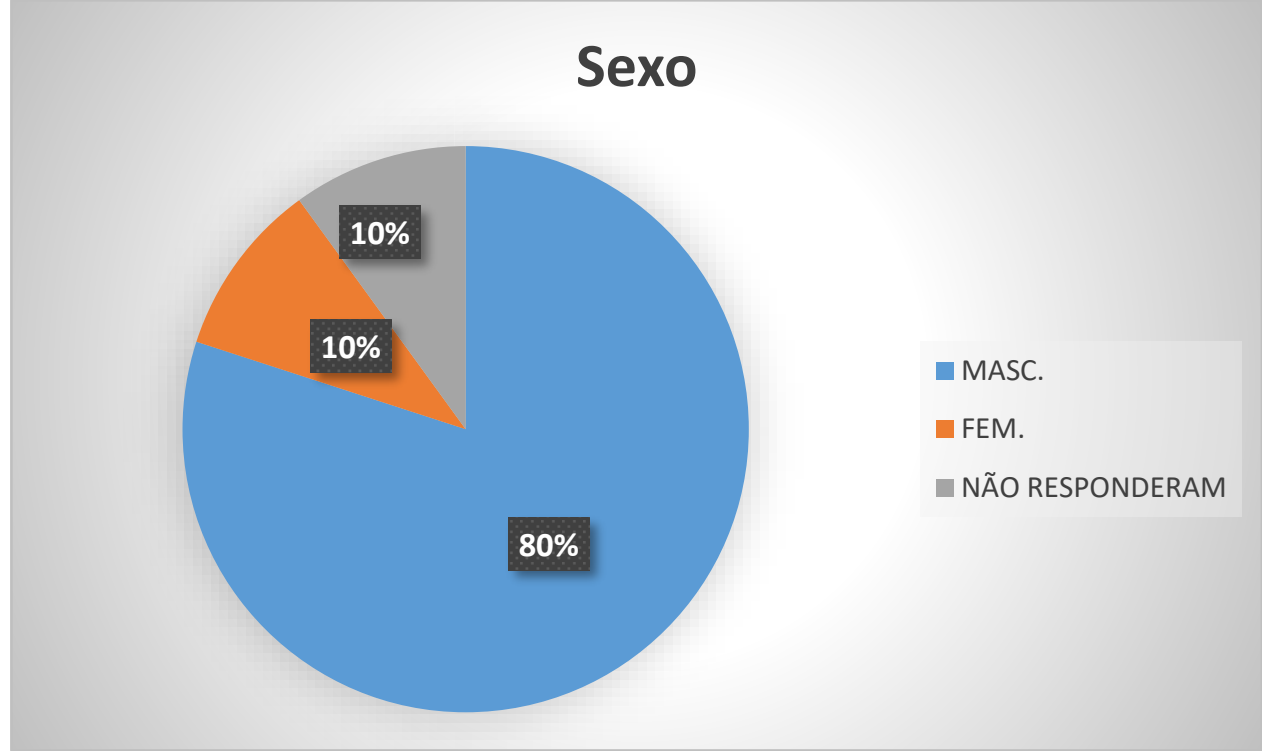

Fonte: Elaborado pelo autor. 2017.

O gráfico 19 (próxima página) apresenta a faixa etária dos participantes. Conforme é possível analisar 30\% se declararam entre 35 e 45 anos, $20 \%$ na faixa de 45 a 55 anos e $40 \%$ se declararam com 55 anos ou mais. 10\% não responderam ao item.

Gráfico 19 - Idade ${ }^{84}$

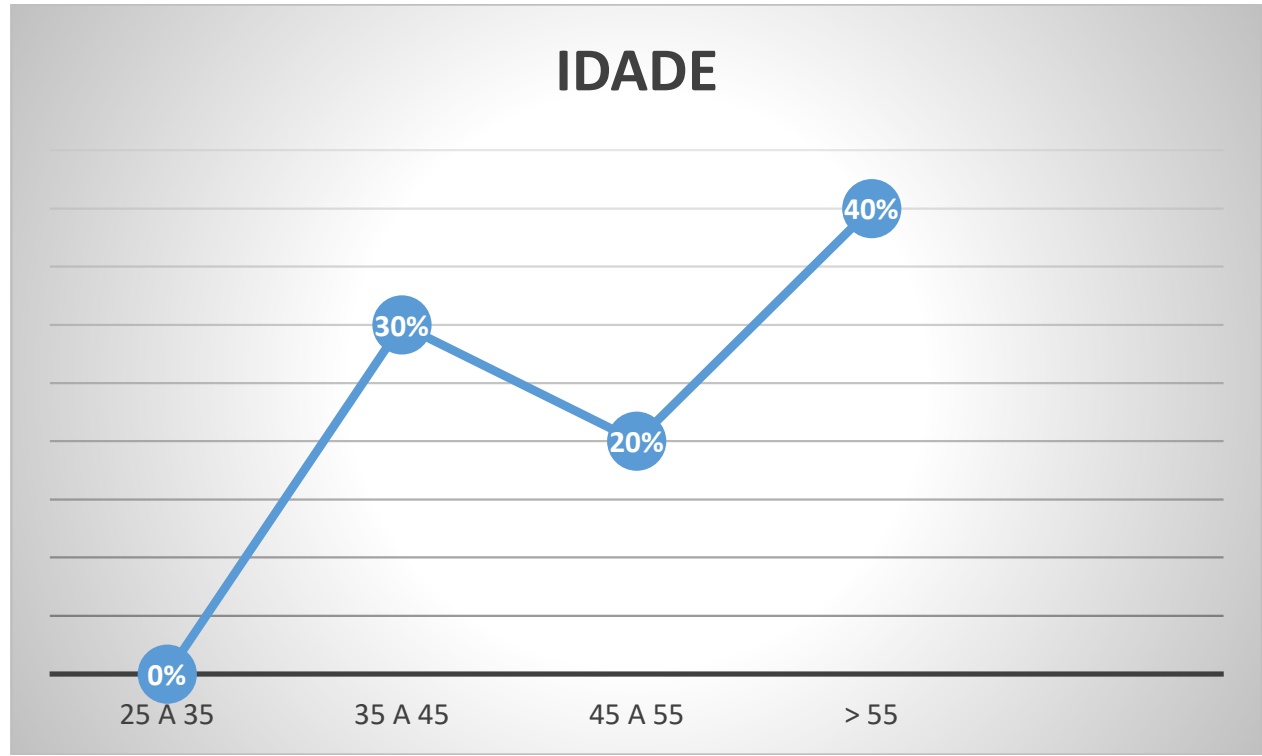

Fonte: Elaborado pelo autor. 2017

84 10\% dos participantes não responderam esta questão. 
Por último, neste subcapítulo, é apresentado o gráfico 20 no qual são demonstrados os partidos dos parlamentares que aceitaram o convite para participar desta pesquisa.

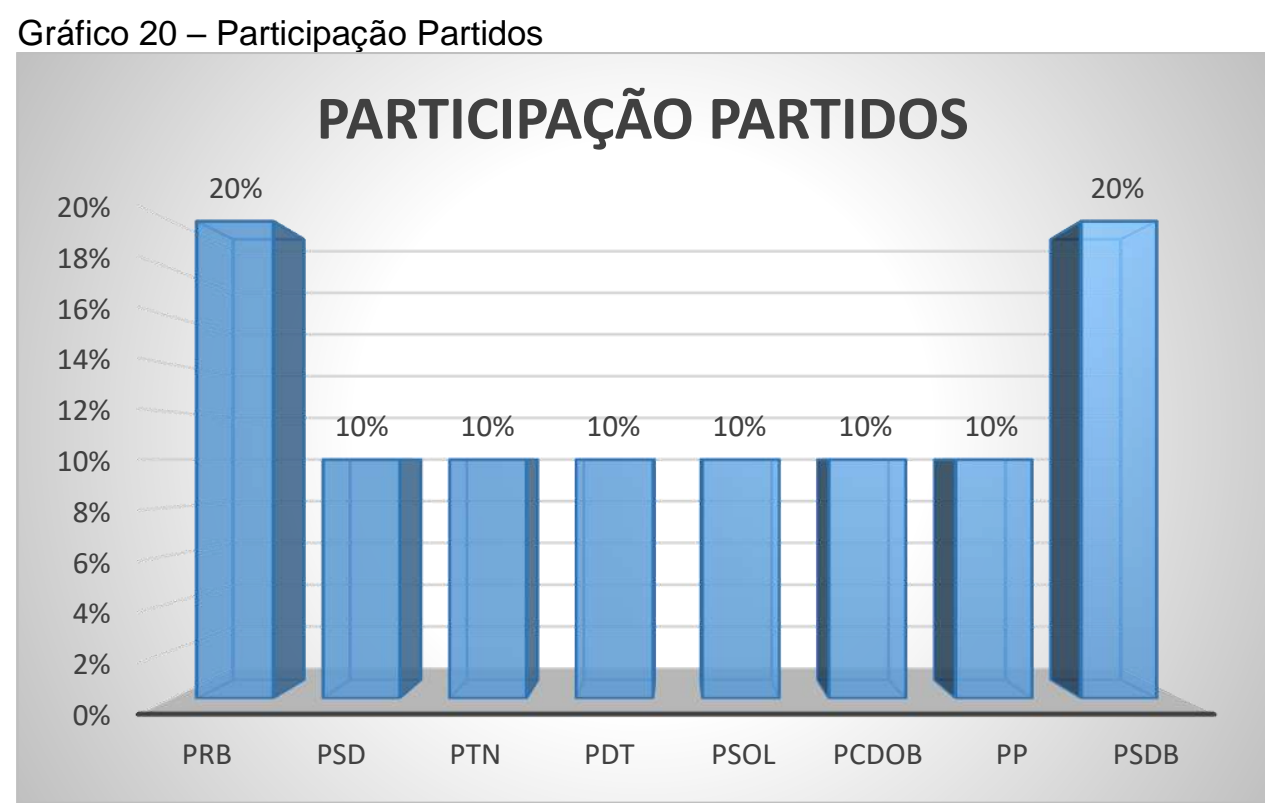

Fonte: Elaborado pelo autor. 2017.

Conforme é possível analisar os partidos com maior participação foram 0 Partido Republicano Brasileiro (P. R. B) e o Partido da Social Democracia Brasileira (P.S.D.B.) com 20\% cada um. Os demais partidos, sendo: Partido Social Democrático (P. S. D.), Partido Trabalhista Nacional (P. T. N), Partido Democrático trabalhista (P.D.T.), Partido Socialismo e Liberdade (P.S.O.L) e Partido Comunista do Brasil (P.C.do B.), Partido Progressista (P.P.) tiveram, respectivamente, 10\% de participação cada na pesquisa.

No próximo subcapítulo analisaremos os dados obtidos na pesquisa em relação ao Uruguai. 


\subsection{PESQUISA URUGUAI}

Neste subcapítulo serão apresentados os dados obtidos na pesquisa bibliográfica referente ao processo de elaboração da lei de Interrupción Voluntaria del Embarazo - I.V.E..

A pesquisa, referente aos dados do parlamento da Republica Oriental do Uruguai, desenvolveu-se com a utilização do Diário de Sessão de número $3.813^{85}$. Este Diário, em especial, traz o debate na Cámara dos Representantes do parlamento Uruguaio a respeito do, até então, projeto de lei I.V.E. que despenalizaria a realização de aborto, regulamentando o I.V.E..

Os dados foram retirados do referido texto tendo como objeto de análise os pronunciamentos dos deputados (as) a respeito do tema (Ata de número 3.813 da Câmara de Representantes do parlamento uruguaio. Setembro de 2012). A pesquisa focou na busca dos seguintes dados: Situação Demográfica; Aborto Crime; Condição de Realização dos Abortos/ Condição de Saúde Pública; Princípios Biológicos (Existência de Vida desde a Concepção); Inconstitucionalidade do Projeto; Legislação Atual Ineficaz; Direito a Vida da Mulher; Princípios Religiosos; Direitos Sexuais e Reprodutivos e; Direito a Vida (Feto).

Os dados retirados foram computados em sistema binário, onde " 0 " significaria "não" e "1" significaria "sim". Estes dados foram computados em tabelas, possibilitando assim, a construção dos gráficos para análise.

A lei Interrupción Voluntaria del Embarazo foi apresentada como projeto de lei ao parlamento Uruguaio na Câmara do Senado pelos senadores (as), Ernesto Agazzi, Alberto Couriel, Susana Dalmás, Juis José Gallo Imperiale, Eduardo Lorier, Daniel Carlos Martinez Villaamil, Rafael Michelini, Constanza Moreira, Enrique Rubio, Jorge Saraiva, Héctor Tajam, Lucía Topolansky e Mônica Xavier.

No senado seu debate foi iniciado em junho de 2011, sendo aprovado no final de dezembro do mesmo, sendo então, remetido para a Câmara dos Representantes para suas considerações, objeto de estudo desta pesquisa.

85 URUGUAY, República Oriental del. Diario de Sesiones. Cámara de Representantes: $52^{a}$ Sesión (Extraordinaria). Número 3.813. XLVII Legislatura. Montevideo, Martes 25 de Setiembre de 2012. Acessado em 12 de março de 2017. Disponível em: https://legislativo.parlamento.gub.uy/temporales/36 729948971965.PDF 
A escolha da Câmara de representantes deu-se pelo fato da proximidade de análise, visto que, os projetos relativos ao tema no Brasil, encontram-se ainda em processo de analises pelas comissões da Câmara dos Deputados brasileira.

\subsubsection{Dados Obtidos}

A Cámara de Representantes do Uruguai era composta em 2012 basicamente pelos quatro partidos que existem em seu sistema político, sendo eles o Partido Frente Amplio (P.F.A.), Partido Nacional (P.N.), Partido Colorado (P.C.) e, Partido Independiente (P.I.) $)^{86}$. Estes partidos compunham a câmara da seguinte forma (gráfico na próxima página):

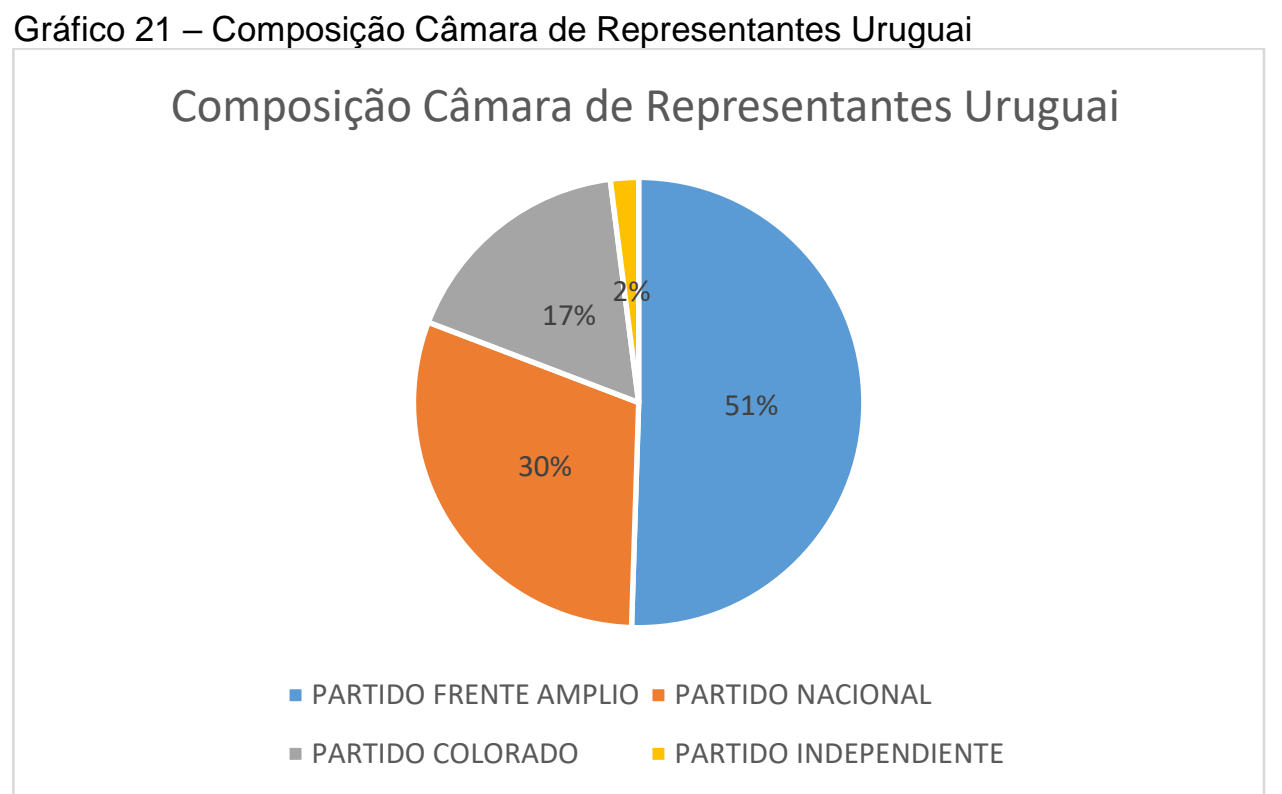

Fonte: Elaborado pelo autor. 2017.

Com 50 deputados na casa, o Partido Frente Amplio, dominava a Câmara com $51 \%$ de seu efetivo. Esta informação possui relevância, visto que, para ser aprovado, um projeto de lei deve obter nesta casa $51 \%$ dos votos, ou seja, o apoio de um partido com este número de votos traz ao debate um peso relevante.

${ }^{86}$ Dados referentes a XLVII Legislatura 2010-2015. 
Em segundo lugar, com 30 deputados, encontra-se o Partido Nacional, representando $30 \%$ do efetivo. Este número, somado a alguns aliados políticos, leva ao debate a possibilidade de acirradas discussões.

Com poucos representantes, e com relativa importância conforme veremos mais a frente, encontram-se o Partido Colorado e o Partido Independiente com, respectivamente, 17 deputados (17\%) e 2 deputados (2\%).

A participação dos mencionados partidos no debate político é responsável pelo desenvolvimento e votação de projetos de leis. Na pesquisa em questão, a utilização da tribuna pelos deputados se deu da seguinte maneira:

Conforme verificamos no gráfico 22, o Partido Frente Amplio, dominou o debate, com $26 \%$ do total de deputados da Câmara de Representantes se pronunciando a respeito do tema. O Partido Nacional ficou em segundo com $19 \%$ do total de deputados discursando na tribuna seguido pelo Partido Colorado, com 8\%, e pelo Partido Independiente, com 2\%. Do total de deputados que compõem a Câmara de Representantes do Uruguai, $42 \%$ não se pronunciaram a respeito do debate.

Gráfico 22 - Deputados na Tribuna

\section{DEPUTADOS NA TRIBUNA}

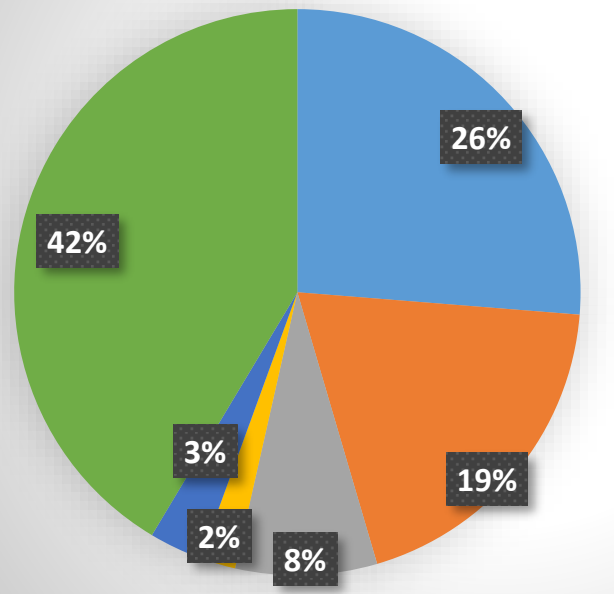

- PARTIDO FRENTE AMPLIO

- PARTIDO NACIONAL

- PARTIDO COLORADO

- PARTIDO INDEPENDIENTE

- NÃO IDENTIFICADO

- NÃO PARTICIPARAM

$8 \%$

Fonte: Elaborado pelo autor. 2017. 
Dentro dos partidos, a participação desenvolveu-se da seguinte maneira:

Gráfico 23 - Participação do Partido no Debate

\section{PARTICIPAÇÃO DO PARTIDO - DEBATE}

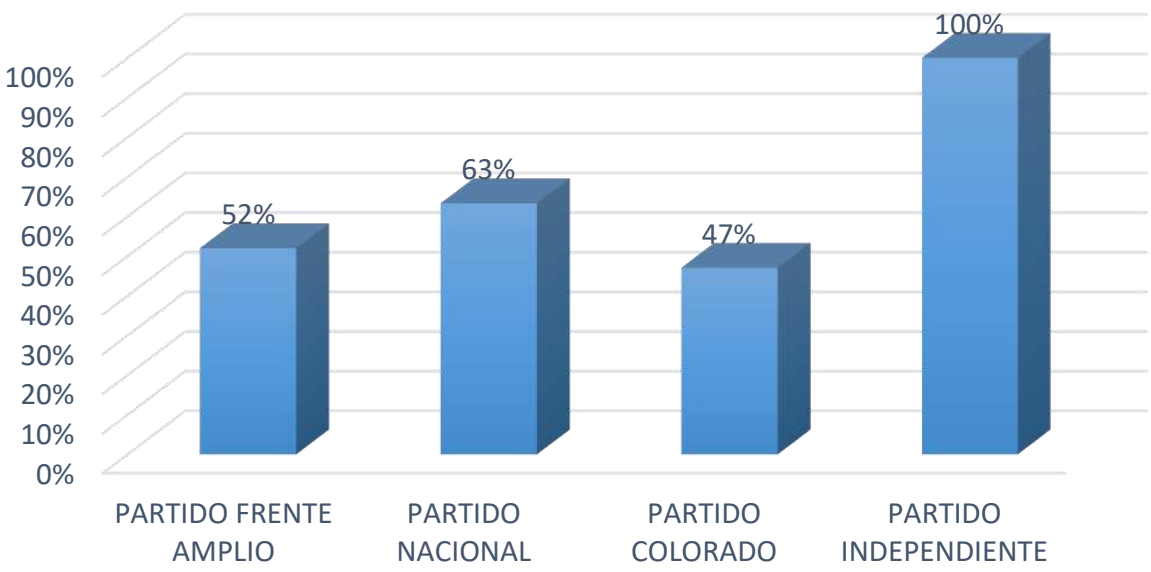

Fonte: Elaborado pelo autor. 2017.

Os dois representantes do Partido Independiente utilizaram a tribuna para se apresentar (100\%). O Partido Nacional obteve 63\% de participação do total de deputados vinculados a ele, seguido pelo Partido Frente Amplio com 52\% e Partido Colorado com $47 \%$ de seus membros.

A analise a seguir retrata os principais pontos defendidos pelos deputados, sendo que, inúmeras vezes se baseavam em mais de um ponto. Desta forma, o cálculo da porcentagem é zerado a cada novo item, representando então, a porcentagem de deputados que utilizaram aquele ponto e não a soma total dos pontos e sua utilização no debate. 
Gráfico 24 - Partido Nacional

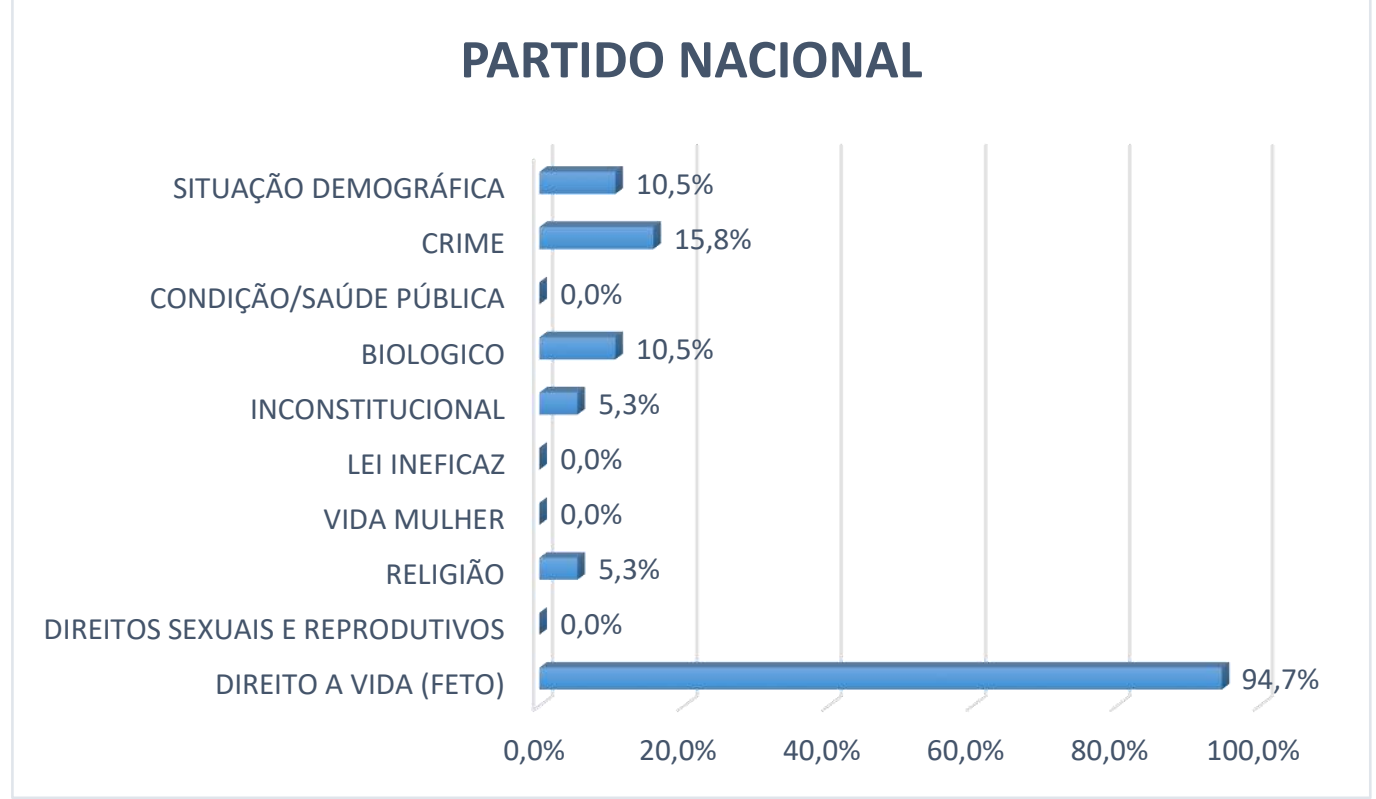

Fonte: Elaborado pelo autor. 2017.

Os deputados vinculados ao Partido Nacional (P.N.), defenderam a não aprovação do projeto do I.V.E., tendo como principais argumentos o Direito a Vida do Feto, representando a cifra de $94,7 \%$ dos deputados que utilizaram a tribuna. Utilizaram nesta argumentação informes relativos ao período gestacional, indicando, a existência de vida e defendendo-a.

A Situação Demográfica representou para o P.N. a relevância de 10,5\% dos deputados que se pronunciaram a respeito do tema. A principal preocupação destes deputados era referente a pequena população ostentada pelo Uruguai e que a regulamentação/despenalização do aborto poderia afetar no futuro, inclusive, o mercado de trabalho, visto que, a população do país já ser, boa parte, superior a meia idade.

Baseando-se em conceitos Científicos/Biológicos, 10,5\% defenderam a existência de vida e descartaram a utilização do aborto, porém, não fizeram menção ao direito a vida. 5,3\% basearam suas convicções em conceitos religiosos e 15,4\% defenderam a negativa sob a alegação de ser o aborto crime,sob os aspectos legal $\mathrm{e}$ moral. 5,3\% dos deputados do P.N., também alegaram a inconstitucionalidade do projeto. Para melhor compreensão, vide Gráfico 24.

Os deputados do Partido Colorado, na utilização da tribuna defenderam três pontos conforme pode ser verificado no gráfico a seguir: 
Gráfico 25 - Partido Colorado

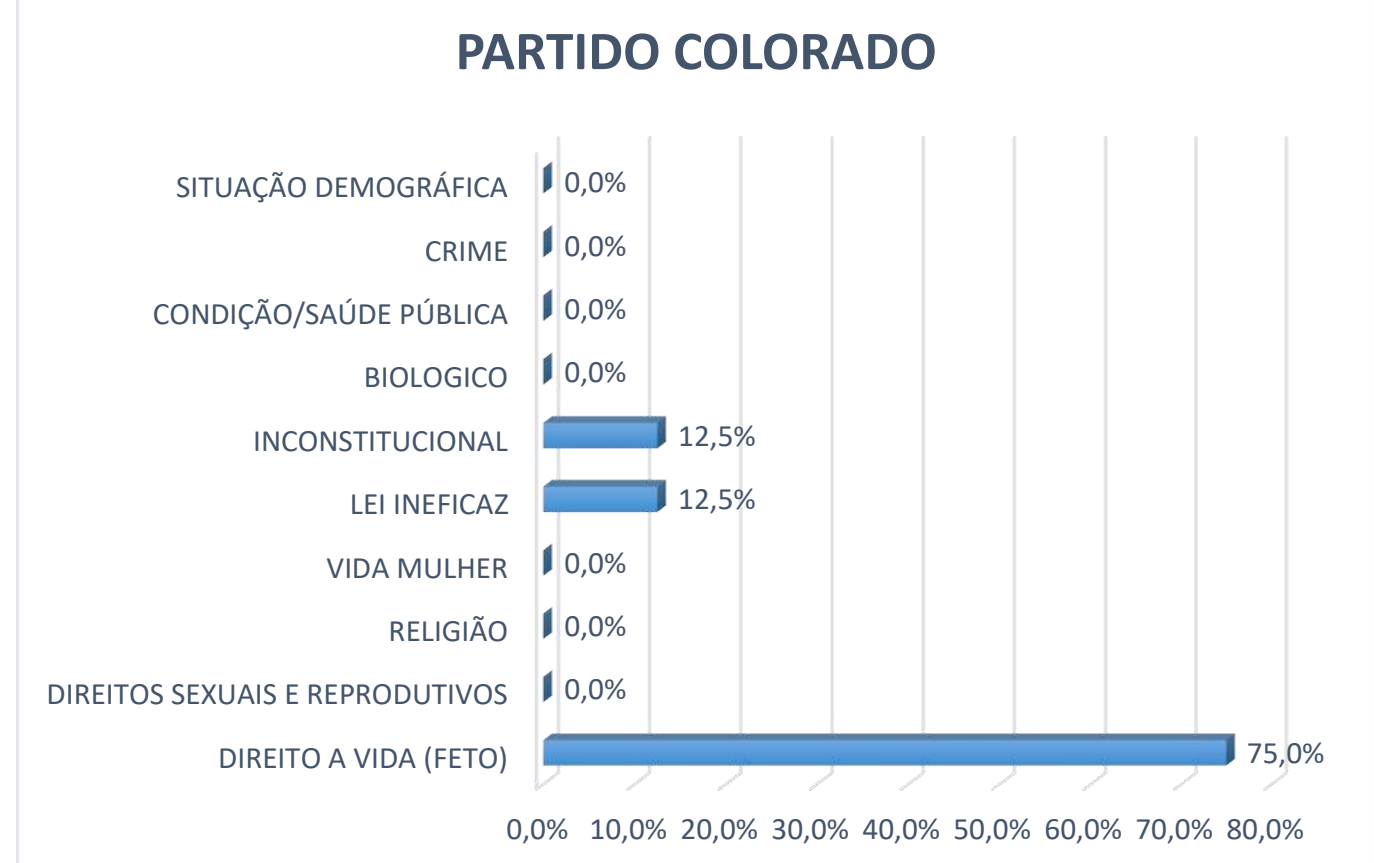

Fonte: Elaborado pelo autor. 2017.

A primeira alegação constatada é referente ao Direito a Vida do Feto representando a cifra de $75 \%$ dos pronunciamentos dos deputados do P.C., outro ponto defendido pelos representantes do partido fora relativo a inconstitucionalidade do projeto de lei, representando $12,5 \%$. Porém, mesmo declarando-se abertamente contra o projeto de modificação da legislação, $12,5 \%$ dos deputados reconhece a ineficácia da atual legislação.

Os dois representantes do Partido Independiente (P.I.) divergiram em suas opiniões, conforme gráfico abaixo. Divididos, os deputados representaram 50\% em relação ao Direito a Vida de Feto e 50\% os Direitos Sexuais e Reprodutivos. 
Gráfico 26 - Partido Independiente

\section{PARTIDO INDEPENDIENTE}

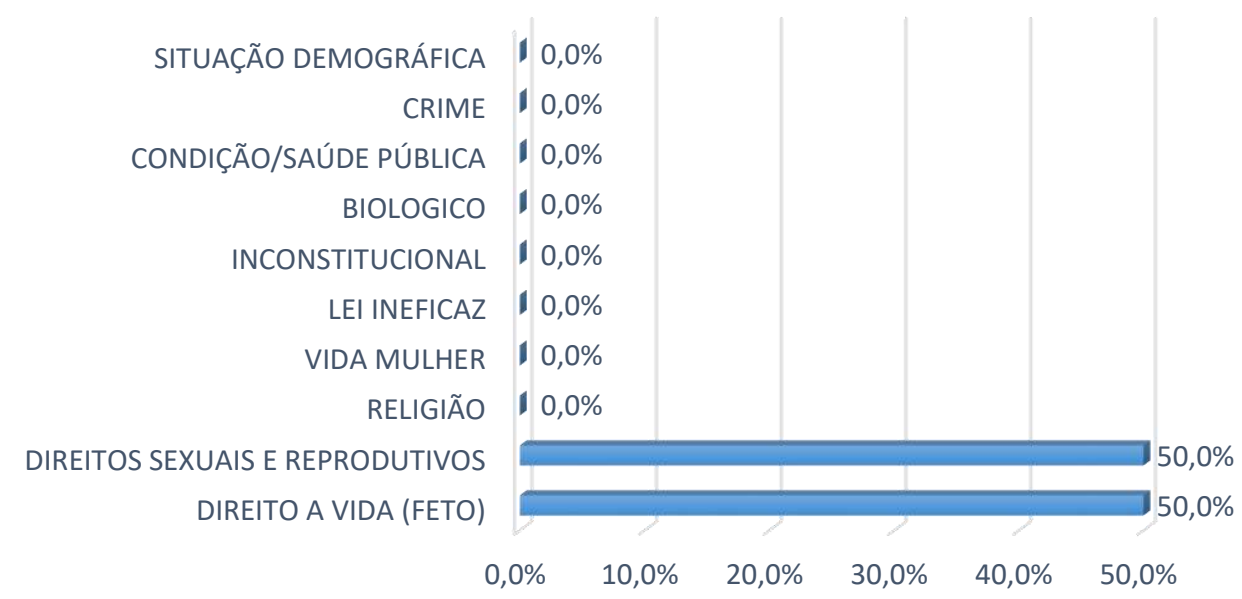

Fonte: Elaborado pelo autor. 2017.

O partido com maior pluralidade de opiniões foi o Partido Frente Amplio (P.F.A.), porém, em grande maioria apoiando a aprovação do projeto. Abaixo verificamos a diversidade dos pronunciamentos dos representantes do partido.

Apenas um deputado do P.F.A., representando 3,8\% dos deputados com fala pelo partido, defendeu o direito a vida do feto. Em suas falas, os demais representantes defenderam a aprovação do projeto, baseando-se em: 15,4\% nas condições que os abortos ilegais são realizados e que este fato condiciona um problema de saúde pública; 15,4\% afirmaram a ineficácia da atual legislação; 11,5\% basearam sua opinião no Direito a Vida da Mulher; Grande maioria, $84,6 \%$, além dos pontos acima tratados, basearam seus votos nos Direitos Sexuais e Reprodutivos. Ver gráfico 27 (próxima página). 
Gráfico 27 - Partido Frente Amplio

\section{PARTIDO FRENTE AMPLIO}

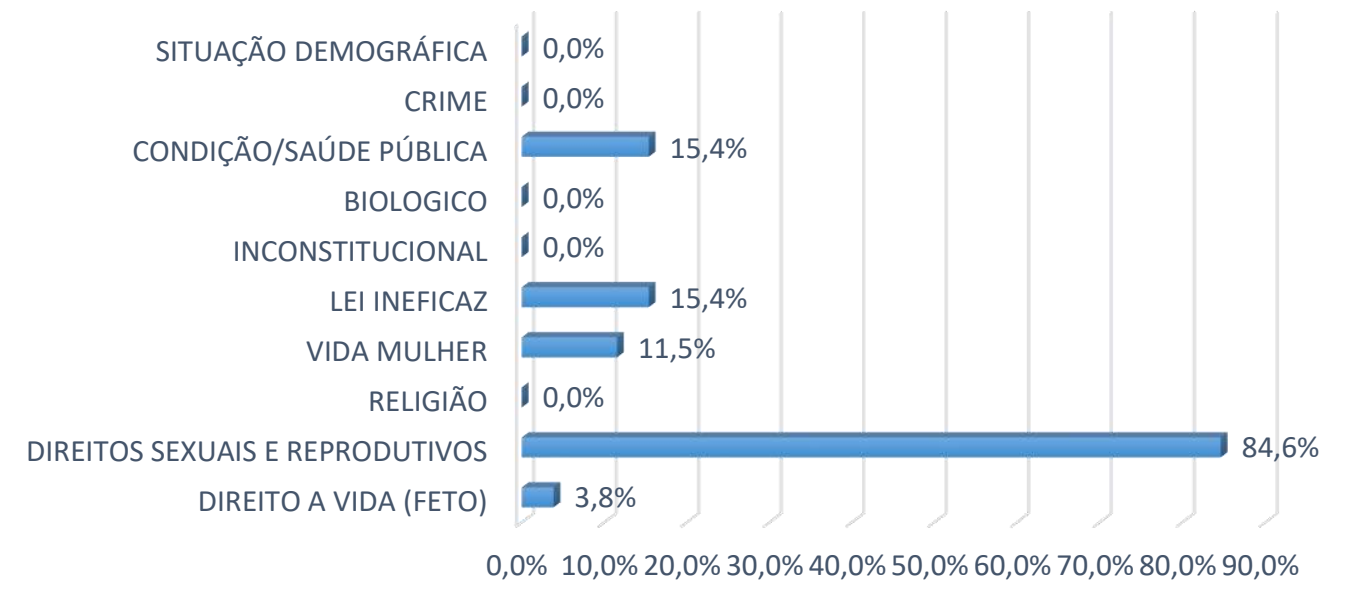

Fonte: Elaborado pelo autor. 2017.

Analisando todos os parlamentares que se pronunciaram é possível chegar ao gráfico 28 , no qual percebe-se a linha tênue, que divide o congresso a respeito do tema. A variação de justificativas dos representantes é expressa neste gráfico, a cada tema o índice é calculado na utilização total e não na soma de todos os pontos.

Gráfico 28 - Pontos Analisados

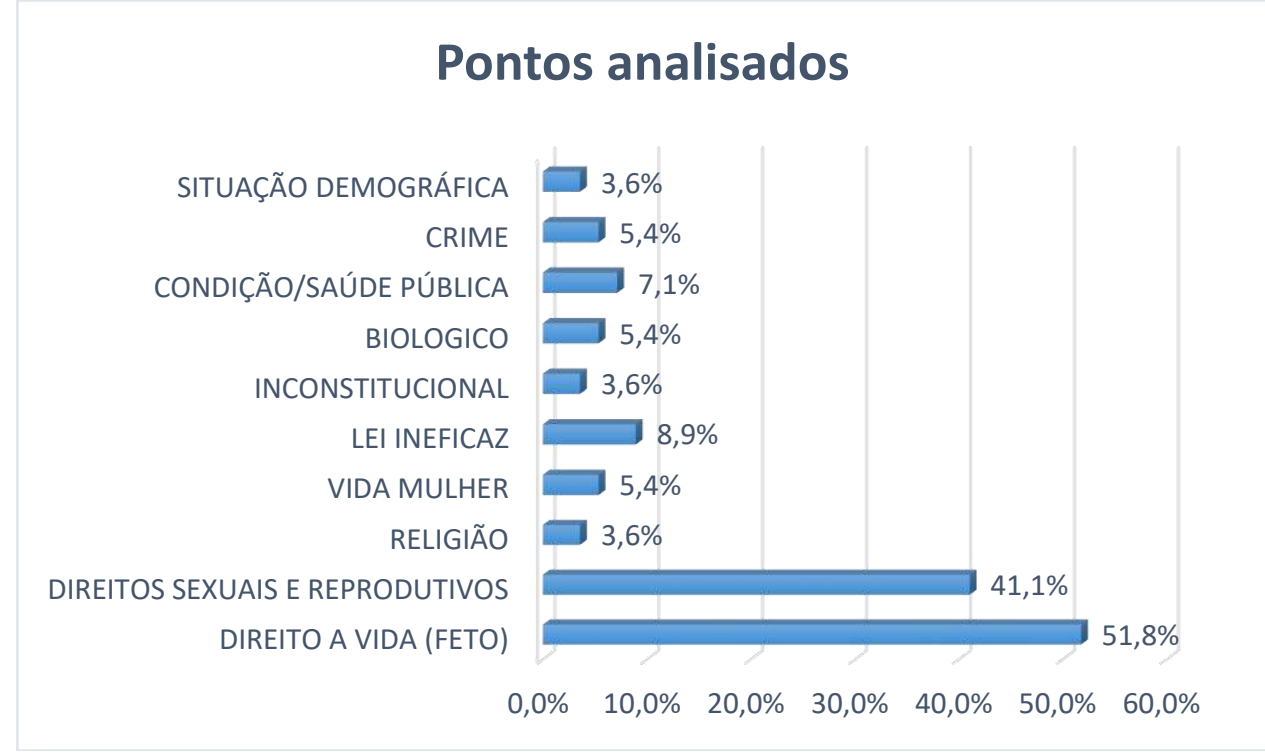

Fonte: Elaborado pelo autor. 2017. 
De forma geral, calculando-se a porcentagem de utilização dos temas como justificativa do voto obtém-se o Gráfico 29 , no qual podemos confirmar a pequena diferença nas justificativas, fatos este que, apresenta a grande indecisão do congresso.

Gráfico 29 - Utilização dos Pontos de Justificativa

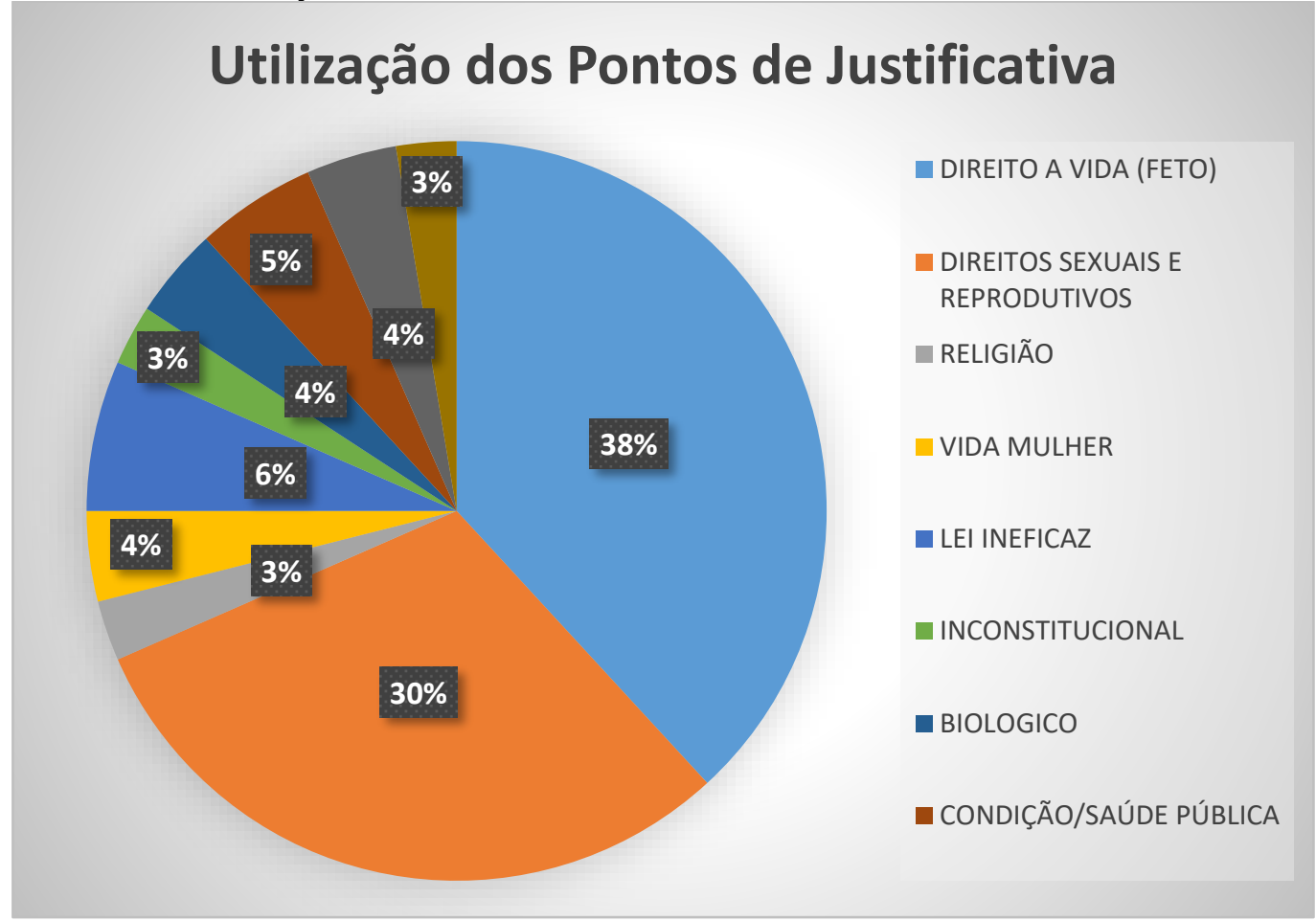

Fonte: Elaborado pelo autor. 2017.

Os temas analisados na pesquisa podem ser resumidos em dois pontos gerais, Favorável a aprovação do Projeto e Negativo a aprovação do projeto. Considerando favorável os tópicos Direitos Sexuais e Reprodutivos, Direito a Vida da Mulher, a ineficácia da lei e a Condição/Saúde Pública. Negativo ao projeto, foram considerados os temas Direito a Vida (feto), Religião, Inconstitucionalidade do Projeto, Fator Biológico/Ciência, Aborto como Crime e a Situação Demográfica. Desta forma, chegamos a relação Geral dos Temas, visualizada a seguir no gráfico 30 (próxima página). 
Gráfico 30 - Relação Geral dos Temas

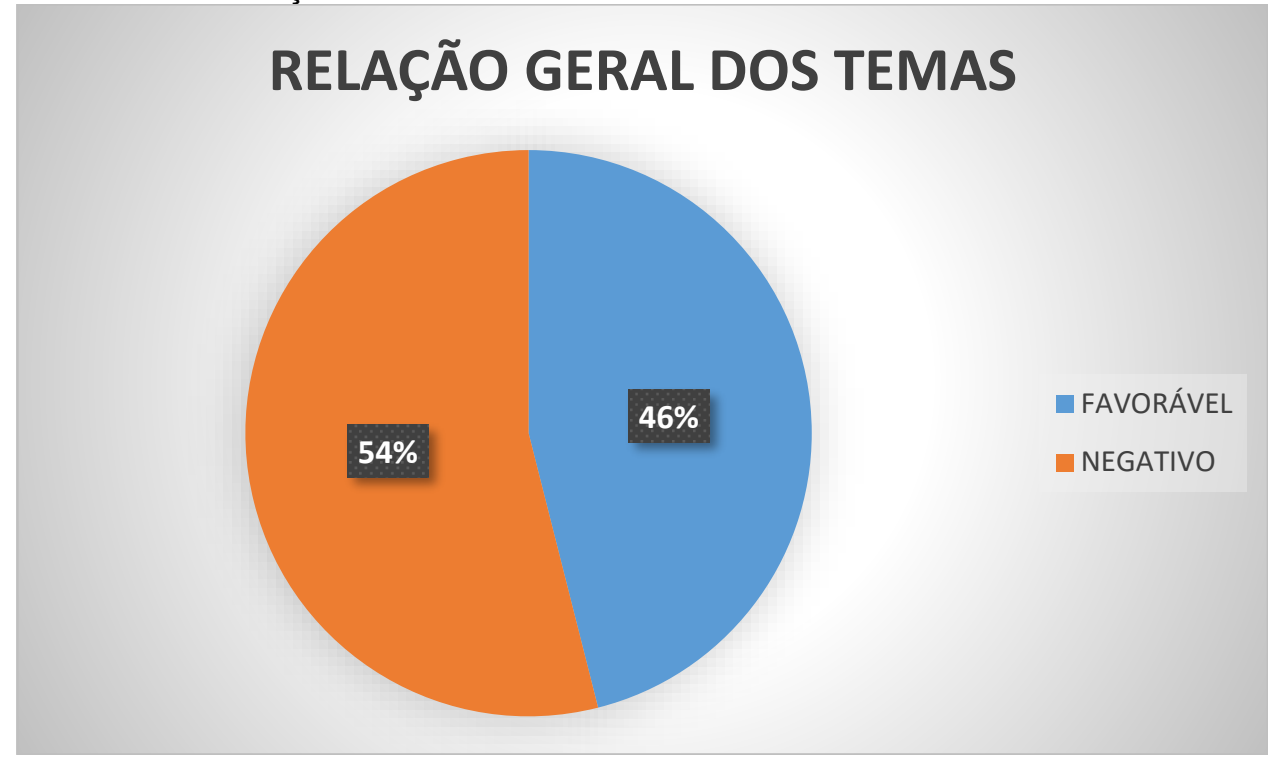

Fonte: Elaborado pelo autor. 2017.

Analisando o gráfico acima é perceptível uma pequena margem de vitória para aqueles que desaprovam o projeto de lei I.V.E., porém, esta situação é modificada na votação final.

Gráfico 31 - Votação Final

\section{VOTAÇÃO FINAL}

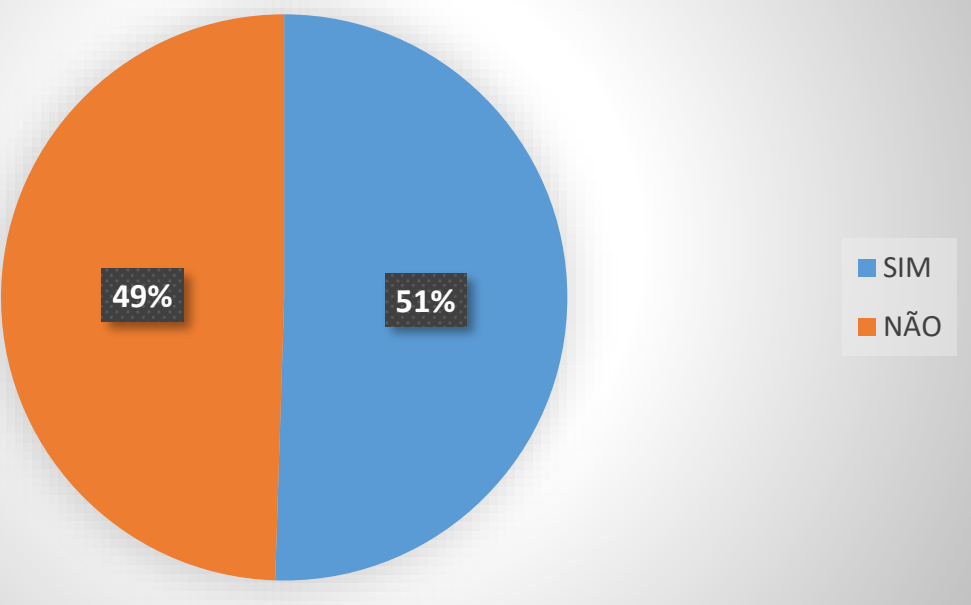

Fonte: Elaborado pelo autor. 2017.

Esta reação se dá pelo fato de que, conforme visto no Gráfico 23, apenas $52 \%$ do P.F.A. se pronunciou a respeito do tema. Devido sua grande quantidade de 
deputados na Câmara de Representantes do Uruguai, no decorrer da votação a situação modificou. Tendo capacidade, por si só, de levantar um projeto de lei, o P.F.A. fora o responsável, em grande maioria, pela aprovação do projeto. O gráfico a seguir analisa a votação por partidos, exemplificando melhor, este fato.

Gráfico 32 - Votação por Partidos

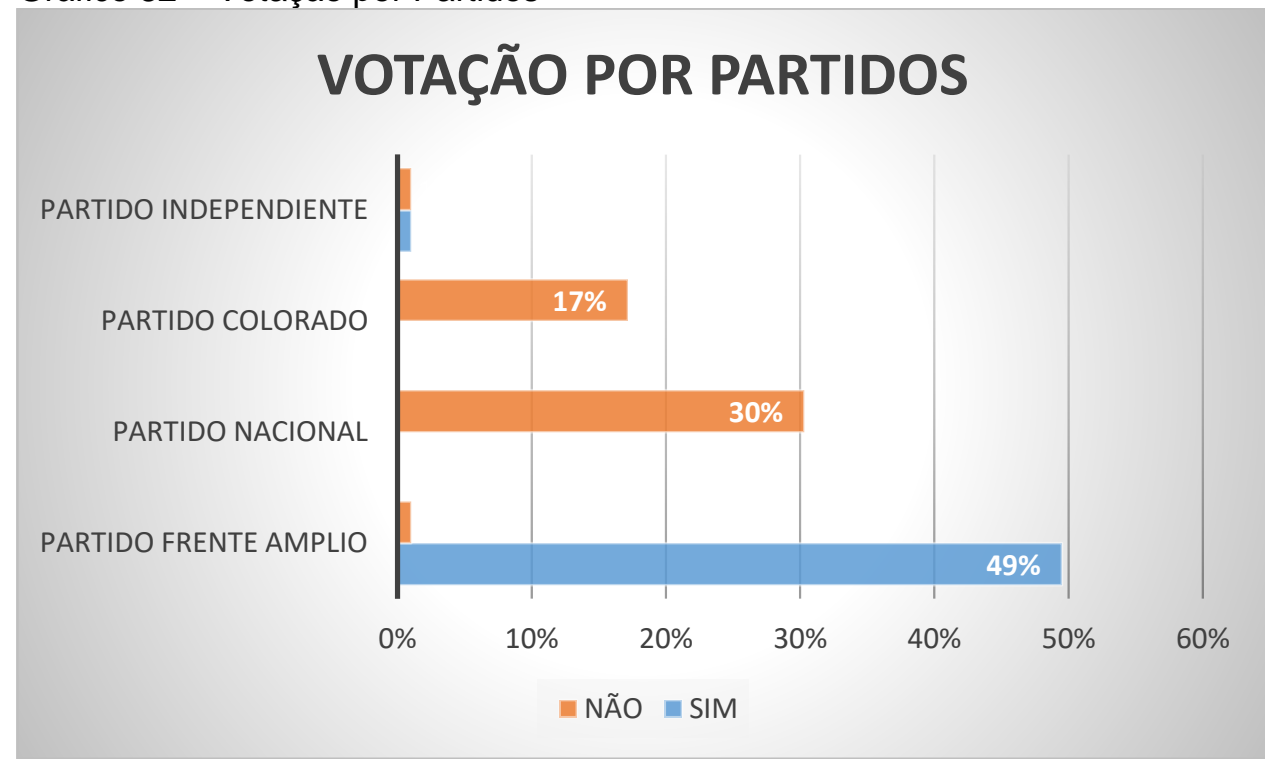

Fonte: Elaborado pelo autor. 2017.

Neste gráfico é perceptível a atuação dos partidos. O P.C. e o P.N. em totalidade declararam-se contra a aprovação do projeto de I.V.E. O P. F.A., em grande maioria, 49 dos 50 membros, declaram-se a favor da aprovação do projeto de lei. $O$ P.I., conforme dito anteriormente, exerceu grande importância para a vitória progressista, visto que, o voto de um deus membros a favor da iniciativa totalizou os 50 votos necessários para a aprovação do projeto de lei. 


\section{CONCLUSÃO}

A presente conclusão é baseada nos conceitos estudados no capítulo I, contextualização histórica realizada no capítulo II e dados e resultados apresentados no capítulo III desta dissertação, assim como, no conhecimento adquirido durante toda a pesquisa.

Conforme é possível verificar no gráfico 30 , a aprovação da Lei de interrupção da gravidez no Uruguai ${ }^{1}$, foi possível graças ao incondicional apoio do Partido Frente Amplio que, representava na legislatura analisada um efetivo suficiente para, inclusive sozinho, levar o projeto de lei à aprovação. Dentre todos os membros do partido apenas um proferiu voto contra a iniciativa, porém, o voto deste, indispensável para a aprovação, foi substituído por um dos dois representantes do Partido Independiente.

Ao contrário de seu vizinho Uruguai, que possui apenas quatro partidos efetivamente registrados e ativos, no Brasil existe uma enorme pluralidade de partidos políticos, cada qual defendendo, a sua maneira, espaços políticos e interesses diversos. Para a aprovação de um projeto de lei na Câmara dos Deputados brasileira, um Deputado, ou partido político, sozinho não possui capacidade para levar a iniciativa adiante. Para tanto formam-se as coligações, blocos e bancadas.

As coligações são formadas pela união de partidos com o objetivo de apresentar os seus candidatos as eleições, ajudando assim, um ao outro, principalmente nas eleições proporcionais. Os blocos atuam de forma parecida com as coligações, porém, desta vez o objetivo não são as eleições, mas sim, em âmbito de governo. São formados dentro do sistema legislativo pelos partidos políticos com o objetivo de alcançar interesses comuns. As bancadas são formadas por parlamentares de variados partidos objetivando um, ou vários, interesses comuns.

As bancadas, blocos e coligações são importantes no processo de aprovação de um projeto de lei. $\mathrm{O}$ apoio de uma bancada e/ou bloco significa a aprovação ou não de um projeto. Nesta legislatura da Câmara dos Deputados do Brasil há uma enorme pluralidade de bancadas e blocos, sendo que, algumas

\footnotetext{
${ }^{1}$ Interrupcion Voluntaria del Embarazo (I.V.E)
} 
apresentam um apoio direto de mais de 230 deputados. Cabe lembrar que mesmo que o parlamentar não participe de uma bancada e/ou bloco, a influência que esta exerce em seu voto não deve ser desconsiderada. $\mathrm{O}$ caso em análise mostrou que, independentemente da participação do deputado nestas bancadas e blocos o seu voto é influenciado por elas.

Um exemplo disto, é o fato da Bancada Evangélica e da Bancada Mista Católica se declararem de forma majoritária contra a regulamentação do aborto. Isto significa uma margem de aproximadamente 350 parlamentares, que tendem a votar contra a iniciativa. Com as negociações internas, este número pode aumentar consideravelmente, pois, apoiar a bancada evangélica, garantido assim, apoio em projetos futuros, pode ser considerado uma boa alternativa em outras votações

É necessário lembrar que um único parlamentar pode fazer parte de diversas bancadas e blocos, defendendo objetivos diversos, inclusive, dentro de um mesmo conceito. Um parlamentar pode se declarar a favor da vida sendo contra o aborto e, ao mesmo tempo, defender a implementação da pena de morte para crimes hediondos.

Outro ponto que deve ser ressaltado é em relação a coligação que acaba exercendo enorme influência sobre o voto do parlamentar, visto que este, pode sofrer com a perda de "favores" dentro do partido por ir contra a determinada iniciativa.

Um outro ponto que difere drasticamente o Brasil do Uruguai é a falta de interesse dos parlamentares brasileiros em participar do debate. Conforme pôde ser analisado no gráfico 20, 58 \% dos parlamentares uruguaios participaram do debate na sessão que votou a aprovação da lei de interrupção da gravidez, expressando assim, suas opiniões referentes ao tema. No Brasil, por sua vez, dentre os parlamentares pesquisados nas comissões selecionadas, apenas $12 \%$, mesmo com todo o caráter sigiloso da pesquisa, conforme pode ser verificado no gráfico 3 , responderam o questionário.

Ainda no gráfico 3 é apresentado o percentual de 49\%, que se refere aos deputados que devolveram o questionário afirmando que, mesmo com o caráter sigiloso da pesquisam, preferiam não expressar opinião referente ao aborto, alegando ser este, um tema muito polêmico. Alguns parlamentares apoiaram sua decisão em preceitos religiosos afirmando alguns, inclusive, que não participaria da pesquisa devido a orientação de seus líderes religiosos. 
Este percentual de $49 \%$ acabou sendo extremamente benéfico para a pesquisa, visto que, acabou confirmando, em parte, a sua hipótese inicial. Os parlamentares da Câmara dos Deputados Brasil acabam praticando uma política de abstenção a debates de temas que possam ser objeto de qualquer controvérsia. Apesar de serem eleitos para representar o povo, possuem maior interesse em permanecer no cargo político que realmente legislar, portanto, evitam expressar qualquer opinião que possa afetá-los de alguma forma em uma próxima eleição.

A polêmica de determinados temas acaba por trazer a eles resistências no Parlamento brasileiro que acaba por praticar, a política de abstenção ao debate, ou seja, escolhem não emitir opiniões a respeito de um tema qualquer. Os projetos envolvendo estas temáticas acabam estagnando nas gavetas das comissões, não chegando sequer, ao debate no plenário. Certas demandas vão sendo deixadas de lado por diversos fatores, tais como: Polêmica do assunto, repressão de determinada bancada, pressão de grupos externos ou fatores religiosos, entre outros

Outra opção encontrada para a falta de interesse dos parlamentares em se debater certas demandas é a origem destes projetos. Conforme pode ser verificado em um levantamento junto as pautas do congresso há, claramente, uma certa preferência por projetos de interesse do governo.

Esta política de abstenção praticada pelo parlamento brasileiro acaba gerando consequências. Sofrendo com o atraso na evolução de determinadas legislações o Poder Judiciário se vê obrigado a exercer uma função atípica e acaba legislando a respeito do assunto no lugar do legislativo. Um exemplo claro disto envolvendo o tema debatido neste trabalho são as decisões do Supremo Tribunal Federal em relação ao aborto do feto anencefálico ${ }^{2}$, que autorizou a realização de aborto nestes casos, e o Habeas Corpus (H.C.) 124.306 de 2016 que, de certa forma, considerou inconstitucional a criminalização do aborto, visto ser incompatível com os direitos fundamentais entre outros aspectos.

Esta política praticada pelo Parlamento brasileiro acaba provocando atrasos e vácuos na legislação. Não apenas referente ao aborto, mas, por se tratar de um tema de natureza bioética, desperta inúmeros outros fatores, tais como éticos, morais, religiosos, científicos, sanitários, etc. Por evitar legislar sobre determinados assuntos o Congresso brasileiro acaba incentivando de maneira indireta práticas

\footnotetext{
${ }^{2}$ Arguição de Descumprimento de Preceito Fundamental №. 54.
} 
ilícitas, a criação de mercados negros, atrasos em pesquisas cientificas envolvendo células troncos, afetando, inclusive, o sistema público de saúde, entre outros.

O aborto no Brasil possui variadas faces. Sendo, podemos enumerar, de natureza moral, de uma sociedade ainda patriarcal; evolução da norma, seguindo os padrões dos Direitos Sexuais e Reprodutivos; saúde pública; um debate entre religião e ciência; legislação ineficiente; ascensão de um mercado negro ou; o sofrimento nas Casas das Aborteiras. Este cenário acaba gerando custos maiores ao sistema de saúde. Não é sobre a morte de mulheres. O debate a respeito do aborto no Brasil é uma mistura de todos estes fatores. O aborto no Brasil deve ser considerado um problema de saúde pública. Mas também é um problema de cunho normativo, social, cultural, moral, religioso e sanitário.

O presente trabalho não pretende ser conclusivo em relação às questões tratadas, mas chamar a atenção, de forma provocativa, para que outros pesquisadores vejam nele um objeto de interesse, tendo em vista as ricas interações sociais que o envolvem. É tema de importância ao qual os pesquisadores, das diversas áreas do conhecimento, podem agregar os resultados de seus estudos. 


\section{REFERÊNCIAS BIBLIOGRÁFICAS}

$A B C M E D, 2015$. Curetagem uterina: o que é? Para que serve? Quando uma mulher deve fazer?. Disponível em: <http://www.abc.med.br/p/exames-eprocedimentos/804884/curetagem-uterina-o-que-e-para-que-serve-quando-uma-mul her-deve-fazer.htm>. Acesso em: 4 mai. 2017.

ABRACINSKAS, L. LÓPEZ GÓMES, A. Mortalidad materna, aborto y salud em Uruguay: um escenario cambiante. Montevideo: MYSU. 2004.

AGAMBEN, Giorgio. Homo Sacer: o poder soberano e á vida nua I. Belo Horizonte: Editora UFMG. 2002.

AQUINO, Estela M. L. et al . Qualidade da atenção ao aborto no Sistema Único de Saúde do Nordeste brasileiro: o que dizem as mulheres?. Ciênc. saúde coletiva, Rio de Janeiro, v. 17, n. 7, p. 1765-1776, July 2012. Available from <http://www.scie lo.br/scielo.php?script=sci_arttext\&pid=S1413-812320120 00700015\&lng=en\&nrm=is o>. access on 06 Sept. 2016.

ARENDT, Hanna. Origens do Totalitarismo. Tradução por Roberto Raposo. São Paulo: Companhia das Letras, 2009.

. Crises da República. São Paulo: Perspectiva. 2004.

ASSMANN, Selvino José. Declaração dos direitos da mulher e da cidadã. Revista Internacional Interdisciplinar INTERthesis, Florianópolis, v. 4, n. 1, p. 1-5, jan. 2007. ISSN 1807-1384. Disponível em: <https://periodicos.ufsc.br/index.php/interthesis/artic le/view/911/10852>. Acesso em: 24 out. 2016. doi:http://dx.doi.org/10.5007/911.

BALANCE 1er ANO DE IMPLEMENTACION DE LEY 18.987 -INTERRUPCION VOLUNTARIA DEL EMBARAZO DECRETO 375/012 REGLAMENTACION DE LA LEY DE IVE (http://www.msp.gub.uy/sites/default/files/archivos_adjuntos/conferencia \%20prensa\%20IVE\%20FEBRERO\%202014.pdf).

BOBBIO, N.; METTEUCCI, N.; PASQUINO, G. Dicionário de política. Brasília: Universidade de Brasília; São Paulo: Imprensa Oficial do Estado de São Paulo. v. 2. 2000.

BOBBIO, Noberto. Estado, governo, sociedade: por uma teoria geral da política. Tradução por Marco Aurélio Nogueira. Rio de Janeiro: Paz e Terra, p. 53-104. 2010. 
BOBBITT, Philip. A Guerra e a Paz na História Moderna: o Impacto dos Grandes conflitos e da política na formação das nações. Tradução Cristiana Serra. Rio de Janeiro: Campus. 2003.

BOLZAN DE MORAIS, José Luis. Do Direito Social aos Interesses Transindividuais. O Estado e o Direito na Ordem Contemporânea, Porto Alegre: Livraria do Advogado, 1996.

BRASIL. Decreto-Lei 2.848, de 07 de dezembro de 1940. Código Penal. Diário Oficial da União, Rio de Janeiro, 31 dez. 1940.

Direitos sexuais, direitos reprodutivos e métodos anticoncepcionais. Ministério da Saúde. Secretaria de Atenção à Saúde. Departamento de Ações Programáticas Estratégicas. Brasília: Ministério da Saúde. 2009.

. Ministério da Saúde (MS). Aborto e Saúde pública no Brasil: 20 anos.

(Série B. Textos Básicos de Saúde). Brasília: MS. 2009.

CABRERA, Oscar. PUCCIO, Luis Lamas. MICHEL, Agustina Ramón. CASAS, Lídia. CAMARGO, Orson. "Sociedade"; Brasil Escola. Disponível em $<$ http://brasilescola.uol.com.br/sociolo gia/sociedade-1.htm>. Acesso em 20 de junho de 2017.

CARVALHO Apud VILLELA, Wilza Vieira et al. Motivos e circunstâncias para o aborto induzido entre mulheres vivendo com HIV no Brasil. Ciênc. Saúde coletiva, Rio de Janeiro, v. 17, n. 7, p. 1709-1719, July 2012. Available from $<$ http://www.scielo.br/scielo.php?script=sci_arttext\&pid=S1413-812320120 00700009\&lng=en\&nrm=iso>. access on 08 Sept. 2016.

CASTRO, Magali de. Um estudo das relações de poder na escola pública de ensino fundamental à luz de Weber e Bourdieu: do poder formal, impessoal e simbólico ao poder explícito. Rev. Fac. Educ., São Paulo, v. 24, n. 1, p. 9-22, Jan. 1998. Available from <http://www.scielo.br/scielo.php?script=sci_arttext\&pid=S0102$25551998000100002 \&$ Ing=en\&nrm=iso >. access on 04 May 2017. http://dx.doi.org/10.1590/S0102-25551998000100002.

CAVALLO, Mercedes. AHUMADA, Claudia. CASAS, Ximena. Los Derechos Reproductivos: Um debate necessário. I Congresso Lationoamericano Jurídico sobre Derechos Reproductivos. Arequipa, Perú. 5,6 y 7 de noviembre de 2009. 1ํed. Lima, Perú. Erre\&Erre artes Gráficas. 2011.

Comitê da CEDAW, "Declaração do Comitê para a Eliminação da Discriminação contra as Mulheres sobre saúde e direitos sexuais e reprodutivos: Além da Revisão da CIPD para 2014". 57 $7^{a}$ Sessão (10 a 28 de fevereiro de 2014), http://www.ohchr.org/Documents/HRBodies/CEDAW/Statements/SRHR26Feb2014.p df (acessado em 05 de maio de 2017). 
CONCEITO, Que. Conceito de Poder. 2016. Disponível em: <http://queconceito.com.br/poder>. Acesso em: 14 mar. 2016.

Conceito de sociedade - O que é, Definição e Significado. 2016. Disponível em: <http://co nceito.de/sociedade>. Acesso em: 10 mar. 2016.

CORRÊA, S. Saúde Reprodutiva, Gênero e Sexualidade: legitimação e novas interrogações. In: GIFFIN, K. e COSTA, S.H. (orgs.). Questões da Saúde Reprodutiva. Rio de Janeiro: FIOCRUZ, p. 39-50, 1999.

CORRÊA, S. e ÁVILA, M.B. Direitos Sexuais e Reprodutivos - Pauta Global e Percursos Brasileiros. In: BERQUÓ, E. (org.). Sexo \& Vida: Panorama da Saúde Reprodutiva no Brasil. Campinas, SP: Editora da UNICAMP, p. 17-78, 2003.

DALLARI, Dalmo de Abreu. Elementos de teoria geral do estado. 30. ed. São Paulo: Saraiva, 2011.

DE ZORDO, Silvia. Representações e experiências sobre aborto legal e ilegal dos ginecologistas-obstetras trabalhando em dois hospitais maternidade de Salvador da Bahia. Ciênc. saúde coletiva, Rio de Janeiro, v. 17, n. 7, p. 1745-1754, July 2012. Available from <http://www.scielo.br/scielo.php?scri pt=sci_arttext\&pid=S1 413-81232012000700013\&lng=en\&nrm=iso>. access on 12 Sept. 2016.

DEL PRIORE, Mary. Ao sul do corpo: condição feminina, maternidades e mentalidades no Brasil Colônia. Rio de Janeiro: José Olympio. Brasília, DF: Edunb. 1993.

DIAZ, Elias. Legalidad- legitimidade en el socialismo democrático. Espanha: Editorial Civitas S.A., 1978.

DINIZ, Debora; MEDEIROS, Marcelo. Aborto no Brasil: uma pesquisa domiciliar com técnica de urna. Ciênc. saúde coletiva, Rio de Janeiro , v. 15, supl. 1, p. 959-966, June $2010 . \quad$ Available from http://www.scielo.br/scielo.php?script=sci_arttext\&pid=S1413$81232010000700002 \&$ Ing=en\&nrm=iso . access on 08 Sept. 2016.

Itinerários e métodos do aborto ilegal em cinco capitais brasileiras. Ciênc. saúde coletiva, Rio de Janeiro, v. 17, n. 7, p. 1671-1681, July 2012 . Available from <http://www.scielo.br/scielo.php?script=sci_arttext\&pid=S1413-

$81232012000700002 \& \operatorname{lng}=$ en\&nr $m=$ iso $>$. access on 06 Sept. 2016.

DINIZ, Debora; MEDEIROS, Marcelo; MADEIRO, Alberto. Pesquisa Nacional de Aborto 2016. Ciênc. saúde coletiva, Rio de Janeiro, v. 22, n. 2, p. 653-660, Feb. 
2017. Disponível em : <http://www.scielo.br/scielo.php?script=sci_arttext\&pid=S141381232017000200653\&lng=en\&nrm=iso>. access on 06 May 2017. http://dx.doi.org/10.1590/1413-81232017222.23812016.

DREYFUS, H. I; RABINOW,P. Michel Foucault: Uma Trajetória Filosófica: Para Além da Estrutura e da Hermenêutica. 2ed. Rio de Janeiro: Forense Universitária. 2010, p. 276.

ENGELS, Friedrich. The Origin of Family, Private Property and the state. Nova York: International Publishers. First German edition. 1884. K. Marx na F. Engels, selected Words. Moscou: Progress Publisher. 1993. p. 326-327.

FARIAS, Rejane Santos; CAVALCANTI, Ludmila Fontenele. Atuação diante das situações de aborto legal na perspectiva dos profissionais de saúde do Hospital Municipal Fernando Magalhães. Ciênc. saúde coletiva, Rio de Janeiro, v. 17, n. 7, p. 1755-1763, July 2012 . Available from http://www.scielo.br/scielo.php?script=sci_arttext\&pid=S1413$81232012000700014 \&$ Ing=en\&nrm=iso . access on 06 Sept. 2016.

FERRE MENZA, Zuleika. Evaluación de la despenalización del aborto en Uruguay em la fecundidade adolescente / Zuleika Ferre Menza. Tesis Maestria em Demografía y Estudios de Poblacións. Montevideo: UR.FCS. Unidad Multidisciplinaria. Programa de Población. 2015.

FONSECA, Walter et al. Características sócio-demográficas, reprodutivas e médicas de mulheres admitidas por aborto em hospital da Região Sul do Brasil. Cad. Saúde Pública, Rio de Janeiro, v. 14, n.2, p.279-286. 1998. Available from http://www.scielo.br/scielo.php?script=sci_arttext\&pid=S0102311X1998000200012\&lng=en\&nrm=iso>. access on 12 Sept. 2016.

FOUCAULT, Michel. Microfísica do poder. Rio de Janeiro: Edições Graal, 1979.

. Em defesa da sociedade. Curso no Collège de France (19751976). São Paulo: Ed. Martins Fontes. 2000, p. 289-300.

História da Sexualidade I: a Vontade de Saber. Rio de Janeiro: Edições Graal, 1976.

L'impossible Prison : Recherches sur lê Systeme Pénitentiaire ao XIX Siècle. Paris: Éd.Du Seuil, 1980.

. POWER/KNOWLEDGE. Selected Interviews and Other Writings 1972-1977. Edited by COLIN GORDON. Translated by COLIN GORDON, LEO MARSHALL JOHN MEPHAM, KATE SOPER. Pantheon Books, New York. 1980, p.199. Tradução livre. 
. Vigiar e Punir. Petrópolis: Editora Vozes, 1975.

GALLI, Beatriz. Violência sexual, gravidez indesejada e acesso ao aborto legal: uma abordagem de direitos humanos e igualdade de gênero. Revista de Saúde Sexual e Reprodutiva, Rio de Janeiro, n. 19, 2005.

GOUGES, Olympe de. Declaração dos direitos da mulher e da cidadã - 1791. Disponível em: http://www.direitoshumanos.usp.br/index.php/Documentos-anteriores$\%$ C3\%A0-cria\%C3\%A7\%C3\%A 3o-da-Sociedade-das-Na\%C3\%A7\%C3\%B5esat\%C3\%A9-1919/declaracao-dos-direitos-da-mulher-e -da-cidada-1791.html> Acessado em 24 de outubro de 2016.

GROPPALI, Alexandre. Doutrina do Estado. Tradução Paulo Edmur de Souza Queiroz. 2 ed. São Paulo: Saraiva. 1962.

HABERMAS, Jürgen. Direito e Democracia: Entre Facticidade e validade. V. 1. Rio de Janeiro: Tempo Brasileiro: 1997.

Quixote. 1990.

Discurso Filosófico da Modernidade. Lisboa: Editora Dom Aires: Editora Paidós. 1999.

. O Conceito de Poder de Hannah Arendt. In FREITAG, Bárbara; ROUANET,Sérgio Paulo (orgs). Habermas - Sociologia. São Paulo: Ática. 1993.

Sociologia. São Paulo: Ática, 1980.

HARDY, Ellen; ALVES, Graciana. Complicações pós-aborto provocado: fatores associados. Cad. Saúde Pública, Rio de Janeiro, v. 8, n. 4, p. 454-458, Dec. 1992. Available from <http://www.scielo.br/scielo.php?script=sci_arttext\&pid=S0102$311 \times 1992000400010 \& \operatorname{lng}=$ en\&nrm=is 0 . access on 12 Sept. 2016.

HEILBORN, Maria Luiza et al . Itinerários abortivos em contextos de clandestinidade na cidade do Rio de Janeiro - Brasil. Ciênc. saúde coletiva, Rio de Janeiro, v. 17, n. 7, p. 1699-1708, July 2012. Available from $<$ http://www.scielo.br/scielo.php?script=sci_arttext\&pid=S1413$81232012000700008 \& \ln \mathrm{g}=$ en\&nrm=iso>. access on 12 Sept. 2016. P. 1704. Grifos do autor.

HELLER, Herman. Saatslehre. 6. Ed. Tubingen: Mohr Siebeck. 1983. 
HERB, Karl Friendrich. Além do bem e do mal: o poder em Maquiavel, Hobbes, Arendt e Foucault. Revista Brasileira de Ciência Política, №10. Brasília, janeiro - abril de 2013, pp. 267-284. 2013.

HOBBES, Thomas. Leviatã ou matéria, forma e poder de um Estado eclesiástico e civil. São Paulo: Martin Claret, 2009.

INE. Anuario estadístico 2014. Montevideo. 2014. Acessado em 08 de setembro de 2016

em <http://www.ine.gub.uy/documents/10181/37281/Anuario2014.pdf/021afc83e6c9-43c9-8a7e-302f7a5 eeed6>.

KANT, Immanuel. A Fundamentação da Metafísica dos Costumes. A Doutrina Universal do Direito.

KELSEN, Hans. Teoria geral do direito e do estado. Tradução: Luis Carlos Borges. 3 ed. São Paulo: Martins Fontes, 2000.

KRECH, David; CRUTCHFIELD, Richard S.; BALLACHEY, Egerton L.. O Indivíduo na Sociedade: Um Manual de Psicologia Social. São Paulo: Editora da Universidade de São Paulo, 1962. 656 p. 2 v. Tradução de Dante Moreira Leite e Miriam L. Moreira Leite.

KULCZYCKI, A. De eso no se habla: aceptando el aborto em México. Estudios demográficos y urbanos. 18(2). 2003.

LAURENTI, Ruy; JORGE, Maria Helena Prado de Mello; GOTLIEB, Sabina Léa Davidson. A mortalidade materna nas capitais brasileiras: algumas características e estimativa de um fator de ajuste. Rev. bras. epidemiol., São Paulo, v. 7, n. 4, p. 449-460, Dec. $2004 . \quad$ Available from http://www.scielo.br/scielo.php?script=sci_arttext\&pid=S1415790X2004000400008\&lng=en\&nrm=iso . access on 08 Sept. 2016.

LEAL, Ondina Fachel. "Levante a mão aqui quem nunca tirou criança!": revisitando dados etnográficos sobre a disseminação de práticas abortivas em populações de baixa-renda no Brasil. Ciênc. saúde coletiva, Rio de Janeiro , v. 17, n. 7, p. 16891697, July 2012 Available from http://www.scielo.br/scielo.php?script=sci_arttext\&pid=S1413$81232012000700007 \&$ Ing=en\&nrm=iso access on 08 Sept. 2016, p. 1693.

LEOCÁDIO, E.M.A. Aborto pós-estupro: uma trama (des) conhecida entre o direito e a política de assistência à saúde da mulher [dissertação]. Distrito Federal: Universidade de Brasília. 2006. 
LIMA, Sarah Dayanna Lacerda Martins. Os Direitos Reprodutivos das Mulheres e a Comissão Interamericana de Direitos Humanos: Uma Análise dos Casos Admitidos entre 2000 e 2013. Revista do Instituto Brasileiro de Direitos Humanos, v. 14, n. 14, 2014.

LOCKE, John. Segundo Tradado sobre o Governo Civil e Outros Escritos. 3 ed. Petrópolis: Vozes, 2001.

LOYOLA, M. A. et al. Os autores respondem. Lacunas da Pesquisa Nacional do Aborto e Agenda para o Futuro. Ciência \& Saúde Coletiva, vol. 17, núm. 7, julio, 2012, pp. 1687-1688.

MACHADO, Gustavo Silveira. Projetos de lei sobre aborto em tramitação na Câmara dos Deputados. 2007.

MACHADO, Roberto. "Por uma Genealogia do Poder". In: FOUCAULT, Michel. Microfísica do Poder. Rio de Janeiro: Edições Graal, 1979.

MACHADO, Teresa Robichez de Carvalho. As consequências jurídicas e sociais da manutenção da criminalização do aborto. Ciênc. saúde coletiva, Rio de Janeiro

v. 17, n. 7, p. 1683-1685, July 2012 .Available from <http://www.scielo.br/scielo.php?script=sci_arttext\&pid=S1413-

$81232012000700004 \& \mathrm{l} n g=e n \& n r m=$ iso $>$. access on 06 Sept. 2016.

MADEIRO, Alberto Pereira; DINIZ, Debora. Serviços de aborto legal no Brasil - um estudo nacional. Ciênc. saúde coletiva, Rio de Janeiro , v. 21, n. 2, p. 563-572, Feb. 2016 .Disponível <http://www.scielosp.org/scielo.php?script=sci_arttext\&pid=S141381232016000200563\&lng=en\&nrm=iso>. access on 06 May 2017. http://dx.doi.org/10.1590/1413-81232015212.10352015.

MALUF, Sahid. Teoria Geral do Estado. 24 ed. rev. atual. São Paulo: Saraiva, 1998.

MAQUIAVEL, Nicolau. O Príncipe: Comentado por Napoleão Bonaparte. Tradução: Pietro Nassetti. $7^{\circ}$ Ed. São Paulo: Editora Martin Claret, 2008.

The discourses. London: Penguin.1983.

MATTAR, Laura Davis. Reconhecimento jurídico dos direitos sexuais: uma análise comparativa com os direitos reprodutivos. Sur, Rev. int. direitos human., São Paulo, v. 5 , n. 8, p. 60-83, June 2008. p. 63. Available from <http://www.scielo.br/scielo.php?script=sci_arttext\&pid=S1806-

64452008000100004\&lng=en\&nrm=iso>. access on 24 Oct. 2016. http://dx.doi.org/10.1590/S1806-64452008000100004. 
MENEZES, Greice; AQUINO, Estela M. L.. Pesquisa sobre o aborto no Brasil: avanços e desafios para o campo da saúde coletiva. Cad. Saúde Pública, Rio de Janeiro, v. 25, supl. 2, p. s193-s204, 2009. Available from <http://www.scielo.br/scielo.php?script=sci_arttext\&pid=S0102-

311X2009001400002\&Ing=en\&nrm=iso>. access on 08 Sept. 2016.

MENGUE, Sotero Serrate; DAL PIZZOL, Tatiane da Silva. Misoprostol, aborto e malformações congênitas. Revista brasileira de ginecologia \& obstetrícia. Rio de Janeiro. Vol. 30, n. 6 (jun. 2008), p. 271-273, 2008.

MONTEIRO, M. F. G. ADESSE, L. Estimativas de aborto induzido no Brasil e Grandes Regiões (1992 - 2005). In: Encontro Nacional de Estudos Populacionais. 15. Anais...Caxambu, Abep. 2006.

NADER, Priscilla Rocha Araújo; BLANDINO, Vanez da Rocha Panetto; MACIEL, Ethel Leonor Nóia. Características de abortamentos atendidos em uma maternidade pública do Município da Serra - ES. Rev. bras. epidemiol., São Paulo, v. 10, n. 4, p. 615-624, Dec. 2007. Available from <http://www.scielo.br/scielo.php?script=sci_arttext\&pid=S1415790X2007000400019\&Ing=en\&nrm=is 0>. access on 12 Sept. 2016.

NEGRI, Antonio; HARDT, Michael. Império. Rio de Janeiro/São Paulo: Ed. Record. 2001.

NUNES, Silvia Alexim. O Corpo do Diabo entre a cruz e a caldeirinha: um estudo sobre a mulher, o masoquismo e a feminilidade. Rio de Janeiro: Civilização Brasileiro. 2000.

PATRIOTA, Tania. Relatório da Conferência Internacional sobre População e Desenvolvimento - Plataforma de Caíro, 1994. Texto Integral do Relatório da Conferência Internacional sobre População e Desenvolvimento. Cairo, Egito. 5 a 13 de setembro de 1994.

PERISSINOTTO, Renato M. Hannah Arendt, Poder e A Crítica Da "Tradição". Lua Nova, São Paulo, № 61: P. 115-138. 2004.

PITANGUY, J. O Movimento Nacional e Internacional de Saúde e Direitos Reprodutivos. In: GIFFIN, Karen e COSTA, Sarah H. (orgs.). Questões da Saúde Reprodutiva. Rio de Janeiro: FIOCRUZ, p. 19-38, 1999.

POGREBINSCHI, T. Foucault, Para Além do Poder Disciplinar e do Biopoder. Lua Nova. Revista de Cultura e Política, São Paulo, n. 63, 2004.

POULANTZAS, Nicos. O Estado, o poder e o socialismo. 4º ed. São Paulo: Paz e Terra, 2000. 
REVEL, Judith. Michel Foucault: conceitos essenciais. Trad. Maria do Rosário Gregolin. São Carlos, SP: Claraluz, 2005.

REZENDE, M. Obstetrícia Fundamental. 11ํed. Rio de Janeiro: Guanabara Koogan. 2008.

RIBEIRO, Renato Janine. A marca do leviatã - linguagem e poder em Hobbes. São Paulo: Ateliê Editorial, 2003.

ROCHA, Maria Isabel Baltar da; ROSTAGNOL, Susana; GUTIERREZ, María Alicia. Aborto y Parlamento: un estudio sobre Brasil, Uruguay y Argentina. Rev. bras. estud. popul., São Paulo, v. 26, n. 2, p. 219-236, Dec. 2009. Available from http://www.scielo.br/scielo.php?script=sci_arttext\&pid=S 0102 $30982009000200005 \&$ Ing=en\&nrm=iso. access on 09 Sept.

ROSSEAU, Jean-Jacques. O Contrato Social. Rio de Janeiro: Tecnoprint, 1762.

ROSTAGNOL, S. Complicaciones post-aborto como uma etapa del processo del aborto: los distintos actores involucrados. In: Foro por los Derechos Reprodutivos, Seminario Regional sobre Monitoreo de la Atención de las Complicaciones post aborto em Hospitales Públicos em Áreas Urbanas. Buenos Aires: 21-22 Abril. 2003.

SANSEVIERO, R. Condena, Tolerancia y Negación. El Aborto em Uruguay. Montevideo: CIIIP. 2003

SAPRIZA, G. Historia de la (des)penalización del aborto em Uruguay."Aborto libre": La corta experiência uruguaya (1934-1938). In NIKI, J. et al. (Des)penalización del aborto em Uruguay: Prácticas, actores y discursos, Abordaje interdisciplinario sobre uma realidade compleja. UdelaR. 2011.

SILVA, José Afonso. Curso de Direito Constitucional Positivo. 25 ed. Revista e atualizada nos termos da Reforma Constitucional, até a Emenda Constitucional n. 48, de 10.8.2005. São Paulo: Malheiros Editores LTDA., 2005.

SINGH, S. MONTEIRO, M. LEVIN, J. Trends in hospitalization for abortion complications and the potential impacto f misoprostol use: the case of Brazil. In: IUSSP Seminar os the Health, Social and Economic Consequences os Unsafe Abortion. México. 2010.

SOARES, Mário Lúcio Quintão. Teoria do Estado. 2 ed. Ver. Atual. Belo Horizonte: Del Rey, 2004. 
TINOCO, Antonio Luiz. Código criminal do Império do Brasil anotado. Ed. Facsimilar, Brasília: Senado Federal/Conselho Editorial. 2003.

TOBIAS, Barreto. Prelecções de direito constitucional - Estudos de Direito. vol. II, Sergipe: E.C.E., 1926.

TONNIES, F. Comunidad y Sociedad. Buenos Aires: Losada. 1947.

UNICEF. Observatorio de los Derechos de la Infancia y la Adolescencia em Uruguay. Álvaro Arroyo et al. Montevideo: UNICEF. 2012.

URUGUAY, República Oriental del. Diario de Sesiones. Cámara de Representantes: $52^{a}$ Sesión (Extraordinaria). Número 3.813. XLVII Legislatura. Montevideo, Martes 25 de Setiembre de 2012. Acessado em 12 de março de 2017. Disponível em: https://legislativo.parlamento.gub.uy/temporales/36 729948971965.PDF

VILLELA, Wilza Vieira et al . Motivos e circunstâncias para o aborto induzido entre mulheres vivendo com HIV no Brasil. Ciênc. saúde coletiva, Rio de Janeiro, v. 17, n. 7, p. 1709-1719, July 2012 . Available from $<$ http://www.scielo.br/scielo.php?script=sci_arttext\&pid=S1413-

$81232012000700009 \&$ In $g=e n \& n r m=i s o>$. access on 06 Sept. 2016.

WEBER, Max. Economia e Sociedade: Fundamentos da sociologia compreensiva. 4ํe ed. Vol. 1. Brasília: Editora Universidade de Brasília. 2009.

WiCHTERICH, Christa. Direitos Sexuais e Reprodutivos. Rio de Janeiro. Heinrich Boll Foundation. 2015.

WORLD HEALTH ORGANIZATION (WHO. Unsafe Abortion: Global and Regional Estimates of the Incidence of Unsafe Abortion and Associated Mortality in 2008. Geneva: WHO, 2011.

2002. World reporto $\mathbf{n}$ violence and health. Geneva: WHO. Abortamento seguro: Orientação técnica e de políticas para os sistemas de saúde. Genebra: OMS. 2004. 


\section{ANEXOS I}

\section{PARECER COMITÊ DE ÉTICA EM PESQUISA UNIEURO}

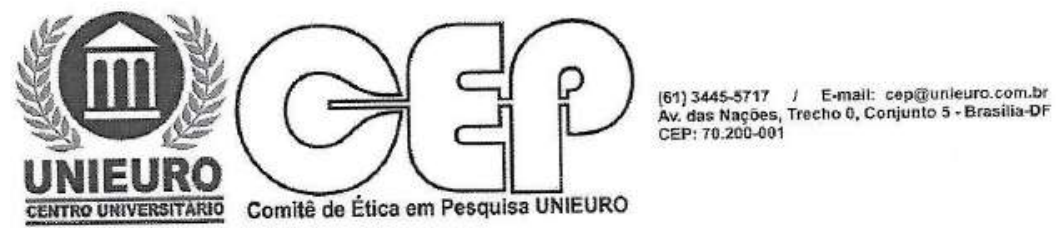

PARECER N 92/2016

Projeto: Aborto da lei: estudo comparativo sobre biōpoder no Brasil e no Uruguai.

Protocolo: 1.830 .115

Pesquisador Responsável: Lucas Freitas de Souza

CAEE: 59438516.6 .0000 .5056

O Comitê de Ética em Pesquisa do Centro Universitário UNIEURO, após apreciação ética do presente projeto, manifesta-se pela APROVAÇÃO do mesmo. Para a emissão do parecer, observaram-se as disposições contidas na resolução n466/12 CNS/MS, que dispöe sobre as diretrizes e normas regulamentadoras em pesquisa envolvendo seres humanos, assim como as suas resoluções complementares. Ressaltamos que o pesquisador deverá observar as responsabilidades que Ihe são atribuídas na Resolução 466/12 CNS/MS, em relação ao desenvolvimento do projeto.

Brasilia, 22 novenforo de 2016 .

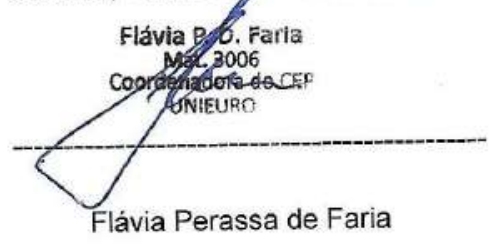




\section{ANEXO II}

\section{PROCESSOS E PROJETOS DE LEI COM TÓPICOS RELATIVOS AO ABORTO, MÉTODOS CONTRACEPTIVOS E TEMAS RELACIONADOS ATIVOS NA CÂMARA DOS DEPUTADOS - BRASIL}

\begin{tabular}{|c|c|c|c|c|c|}
\hline 1. & PDC-1757/2005 & 26. & \multicolumn{3}{|l|}{ PL-3783/2008 } \\
\hline 2. & PL-7443/2006 & 27. & \multicolumn{3}{|c|}{ REC-307/2009 => PL-343/1999 } \\
\hline 3. & REQ-641/2007 & 28. & \multicolumn{3}{|l|}{ REQ-6532/2010 } \\
\hline 4. & REQ-1516/2007 & 29. & \multicolumn{3}{|l|}{ PDC-2840/2010 } \\
\hline 5. & REQ-1517/2007 & 30. & \multicolumn{3}{|l|}{ PL-1085/2011 } \\
\hline 6. & PL-478/2007 & 31. & \multicolumn{3}{|l|}{ PL-1545/2011 } \\
\hline 7. & PL-489/2007 & 32. & \multicolumn{3}{|l|}{ PL-1618/2011 } \\
\hline 8. & PL-1763/2007 & 33. & \multicolumn{3}{|l|}{ PL-3050/2011 } \\
\hline 9. & PL-2433/2007 & 34. & \multicolumn{3}{|c|}{ SRL-15/2012 CCJC $\Rightarrow>$ REL- } \\
\hline 10. & PL-1459/2003 & \multicolumn{4}{|c|}{ 3/2012 CCJC } \\
\hline 11. & PL-4403/2004 & 35. & \multicolumn{3}{|l|}{ REQ-4150/2012 } \\
\hline 12. & PL-4889/2005 & 36. & \multicolumn{3}{|l|}{ PL-3725/2012 } \\
\hline 13. & PL-4703/1998 & 37. & \multicolumn{3}{|l|}{ PDC-565/2012 } \\
\hline 14. & PL-343/1999 & 38. & \multicolumn{3}{|l|}{ PDC-566/2012 } \\
\hline 15. & PL-4917/2001 & 39. & \multicolumn{3}{|l|}{ RIC-3136/2013 } \\
\hline 16. & PL-2423/1989 & 40. & \multicolumn{3}{|l|}{ REQ-7545/2013 } \\
\hline 17. & PL-20/1991 & \multicolumn{4}{|c|}{$21 / 2013$} \\
\hline 18. & PL-1035/1991 & 41. & REQ-7602/2013 & $\Rightarrow$ & $\mathrm{RCl}$ \\
\hline 19. & VTS-1 CSSF => PL-343/1999 & \multicolumn{4}{|c|}{$21 / 2013$} \\
\hline 20. & VTS-6 CSSF $=>$ PL-1135/1991 & 42. & \multicolumn{3}{|l|}{ PL-5069/2013 } \\
\hline 21. & SBT-4 CCJC => PL-5069/2013 & 43. & \multicolumn{3}{|l|}{ PL-6033/2013 } \\
\hline 22. & EMR-1 CCJR => PDC-463/2000 & 44. & \multicolumn{3}{|l|}{ PL-6115/2013 } \\
\hline 23. & EMR-2 CCJC => PL-3783/2008 & 45. & \multicolumn{3}{|l|}{ PL-7633/2014 } \\
\hline 24. & REQ-3768/2008 => RCP-9/2008 & 46. & \multicolumn{3}{|l|}{ PL-882/2015 } \\
\hline 25. & PL-3207/2008 & 47. & \multicolumn{3}{|l|}{ PL-1522/2015 } \\
\hline
\end{tabular}


48. PL-3039/2015

54. PL-4641/2016

49. PL-3983/2015

55. PL-4642/2016

50. REQ-22/2016 CDHM

56. PL-4646/2016

51. REQ-324/2016 CSSF

57. PL-4880/2016

52. REQ-4255/2016

58. PL-5617/2016

53. PL-4396/2016 


\section{ANEXO III \\ TERMO DE CONSENTIMENTO LIVRE E ESCLARECIDO - TCLE}

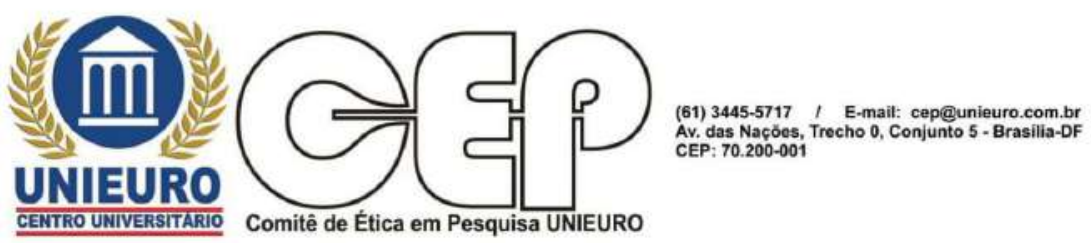

Termo de Consentimento Livre e Esclarecido - TCLE

O (a) Senhor(a) está sendo convidado(a) a participar, na condição de entrevistado, do projeto: O ABORTO DA LEI: estudo comparativo sobre o Biopoder no Brasil e no Uruguai sob responsabilidade do Prof. Dr. MANOEL SANTANA CARDOSO e aluno LUCAS FREITAS DE SOUZA, pesquisadores do Mestrado em Ciência Política do Centro Universitário Unieuro-DF.

O objetivo desta pesquisa é Comparar o debate legislativo em torno do Biopoder, no que tange à questão do aborto, nos parlamentos do Brasil e do Uruguai, no período democrático (1990-2017). Esta pesquisa, justifica-se, visto a a importância do Congresso Nacional brasileiro em fazer frente a estas demandas do Biopoder, em especial, ao legislar sobre o aborto, assim como já feito pelo Congresso Nacional Uruguai, que regulamentou o aborto e estruturou o sistema de saúde para atender ao procedimento.

O (a) senhor(a) receberá todos os esclarecimentos necessários antes e no decorrer da pesquisa e lhe asseguramos que seu nome não aparecerá, sendo mantido o mais rigoroso sigilo, através da omissão total de quaisquer informações que permitam identificá-lo(a). O Questionário será identificado pelo número

(a) senhor(a) poderá se recusar a responder qualquer questão que the traga constrangimento, podendo desistir de participar da pesquisa em qualquer momento sem nenhum prejuízo para o(a) senhor(a).

A sua participação será da seguinte forma: Respondendo o questionário proposto e/ou participando de entrevista relativo ao tema. O tempo estimado para sua realização: 20 minutos.

Os resultados da pesquisa serão divulgados na Instituição Centro Universitário UNIEURO podendo ser publicados posteriormente. Os dados e materiais utilizados na pesquisa ficarão sob a guarda do pesquisador. 


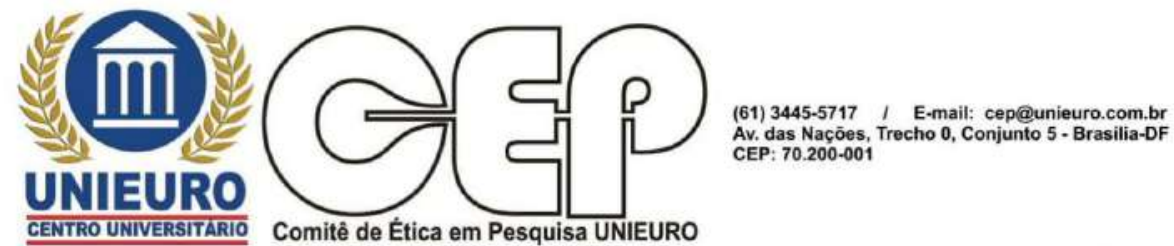

Este projeto possui os benefícios de proporcionar um melhor entendimento do debate Bioético no Brasil, melhorando assim, a capacidade de desenvolvimento de legislação e a compreensão sobre a atual sociedade e não apresenta risco para os participantes ou para a sociedade, sendo que o único risco que o desenvolver da pesquisa corre é relativo a negativa de participação dos membros do congresso.

Se o(a) Senhor(a) tiver qualquer dúvida em relação à pesquisa, por favor telefone para: Prof. Manoel Santana Cardoso, na instituição UNIEURO telefone: (61) $3445-5748$, no horário de 09:00 as 12:00. Aluno: Lucas Freitas de Souza, na instituição UNIEURO, telefone: (61) 99877-1872, em qualquer horário.

Este projeto foi Aprovado pelo Comitê de Ética em Pesquisa do UNIEURO, número do protocolo 1.830.115. As dúvidas com relação à assinatura do T.C.L.E ou os direitos do sujeito da pesquisa podem ser obtidos também pelo telefone: (61) 3445-5717.

Este documento foi elaborado em duas vias, uma ficará com o pesquisador responsável e a outra com o voluntário da pesquisa.

Todas as folhas devem sem rubricadas pelo sujeito da pesquisa ou responsável e pelo pesquisador responsável.

Nome / assinatura

Lucas Freitas de Souza

Pesquisador Responsável

Brasília, de de 2017 


\section{ANEXO IV \\ QUESTIONÁRIO}

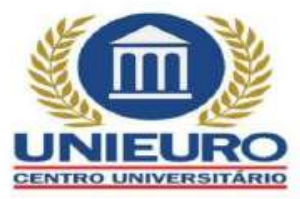

\section{CURSO DE MESTRADO EM CIÊNCIA POLITICA DO CENTRO UNIVERSITÁRIO EURO AMERICANA - UNIEURO}

Questionário:

\section{PESQUISA DE MESTRADO}

Projeto: O ABORTO DA LEI: UM ESTUDO COMPARATIVO DA QUESTÃO DO BIOPODER NO BRASIL E NO URUGUAI

Orientador: Professor Dr. Manoel Cardoso Santana

Mestrando: Lucas Freitas de Souza

\section{PARTIDO:}

SEXO: () Masc. () Fem. IDADE: ( ) 25 A 35 ( ) 35 A 45 ( ) 45 A 55 ( ) ACIMA DE 55

1) É um direito da mulher, fazer o uso do seu corpo, de acordo com suas convicções.
() Concordo Plenamente
( ) Não concordo
( ) Concordo
( )Discordo plenamente
( ) Concordo em parte

2) O Estado não tem o direito de decidir, o que uma mulher deve fazer com seu corpo.
( ) Concordo Plenamente
( ) Não concordo
( ) Concordo
( )Discordo plenamente
( ) Concordo em parte

3) Uma mulher não pode ser obrigada a manter em seu corpo, algo que acredita não lhe fazer bem.
() Concordo Plenamente
() Não concordo
() Concordo
( )Discordo plenamente
( ) Concordo em parte

4) O Estado pode controlar o modo como o indivíduo utiliza o seu corpo.

() Concordo Plenamente
() Concordo
( ) Não concordo
( ) Concordo em parte
()Discordo plenamente 
5) Cabe ao Estado, estabelecer procedimentos para que o indivíduo, no livre manifesto de sua opinião, decida o que fazer com seu corpo.
() Concordo Plenamente
( ) Não concordo
() Concordo
( )Discordo plenamente
( ) Concordo em parte

6) O Aborto é um crime contra a vida.
( ) Concordo Plenamente
( ) Não concordo
( ) Concordo
( ) Discordo plenamente
( ) Concordo em parte

7) Em caso de estupro, o Aborto deve ser permitido a qualquer tempo.
( ) Concordo Plenamente
( ) Não concordo
( ) Concordo
()Discordo plenamente

( ) Concordo em parte

8) Em caso de gravidez de feto anencefálico, o aborto deve ser permitido.
() Concordo Plenamente
( ) Não concordo
( ) Concordo
()Discordo plenamente
( ) Concordo em parte

9) Em casos de gravidez com risco de vida para a gestante, o aborto deve ser permitido/.
() Concordo Plenamente
( ) Não concordo
( ) Concordo
()Discordo plenamente
( ) Concordo em parte

10) A legalização e normatização do aborto traz benefícios a sociedade.
( ) Concordo Plenamente
( ) Não concordo
( ) Concordo
( )Discordo plenamente
( ) Concordo em parte 
CURSO DE MESTRADO EM CIÊNCIA POLITICA

DO CENTRO UNIVERSITÁRIO EURO AMERICANA - UNIEURO

\section{UNIEURO}

11) O aborto do embrião, dentro do prazo biológico estabelecido (12 semanas), não deve ser considerado crime, desde que, feito em ambiente especializado.
() Concordo Plenamente
( ) Não concordo
( ) Concordo
( )Discordo plenamente
( ) Concordo em parte

12) Minha opinião a respeito do aborto é baseada em conceitos religiosos
() Concordo Plenamente
( ) Não concordo
( ) Concordo
( ) Discordo plenamente
( ) Concordo em parte

13) Minha opinião a respeito do aborto é baseada em conceitos científicos
( ) Concordo Plenamente
( ) Não concordo
( ) Concordo
()Discordo plenamente
( ) Concordo em parte

14) O Estado tem o direito de decidir, o que uma mulher deve fazer com seu corpo.
() Concordo Plenamente
() Não concordo
( ) Concordo
()Discordo plenamente
( ) Concordo em parte

15) Uma mulher pode ser obrigada a manter em seu corpo, algo que acredita não lhe fazer bem.
( ) Concordo Plenamente
( ) Não concordo
( ) Concordo
( )Discordo plenamente

( ) Concordo em parte

16) O Aborto não é um crime contra a vida.
( ) Concordo Plenamente
( ) Não concordo
( ) Concordo
( )Discordo plenamente

() Concordo em parte 


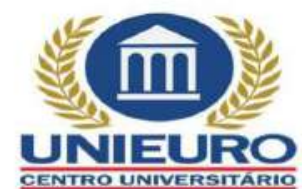

CURSO DE MESTRADO EM CIÊNCIA POLITICA DO CENTRO UNIVERSITÁRIO EURO AMERICANA - UNIEURO

17) A legalização e normatização do aborto traz riscos a sociedade.
() Concordo Plenamente
( ) Não concordo
( ) Concordo
()Discordo plenamente
( ) Concordo em parte

18) Minha opinião a respeito do aborto é baseada em conceitos Éticos e Morais.
() Concordo Plenamente
( ) Não concordo
( ) Concordo
()Discordo plenamente
( ) Concordo em parte 